\title{
Petrographic Characterization and Maceral Controls on Porosity in Overmature Marine Shales: Examples from Ordovician-Silurian Shales in China and the U.S.
}

\author{
Lin Wei $\mathbb{D}^{1,2}$ Shasha Sun $\mathbb{C}^{3},{ }^{3}$ Dazhong Dong, ${ }^{3}$ Zhensheng Shi, ${ }^{3}$ Jia Yin, ${ }^{1,2}$ Shudi Zhang, ${ }^{1,2}$ \\ Maria Mastalerz $\mathbb{D}^{4,5}$ and Xiong Cheng ${ }^{1,2}$ \\ ${ }^{1}$ School of Energy Resources, China University of Geosciences, Beijing 100083, China \\ ${ }^{2}$ Key Laboratory of Marine Reservoir Evolution and Hydrocarbon Enrichment Mechanism, Ministry of Education, \\ Beijing 100083, China \\ ${ }^{3}$ Research Institute of Petroleum Exploration \& Development, PetroChina, Beijing 100083, China \\ ${ }^{4}$ Indiana Geological and Water Survey, Bloomington, IN 47405, USA \\ ${ }^{5}$ Department of Earth and Atmospheric Sciences, Indiana University, 1001 E. $10^{\text {th }}$ St., Bloomington, IN 47405, USA
}

Correspondence should be addressed to Shasha Sun; sunss69@petrochina.com.cn and Maria Mastalerz; mmastale@indiana.edu

Received 27 January 2021; Revised 16 March 2021; Accepted 17 April 2021; Published 1 June 2021

Academic Editor: Kun Zhang

Copyright ( 92021 Lin Wei et al. This is an open access article distributed under the Creative Commons Attribution License, which permits unrestricted use, distribution, and reproduction in any medium, provided the original work is properly cited.

\begin{abstract}
The pore structure characterization and its controlling factors in overmature shales are keys to understand the shale gas accumulation mechanism. Organic matter in source rocks is a mixture of various macerals that have their own specific evolutionary pathways during thermal maturation. Pores within macerals also evolve following their own path. This study focused on petrographic characterization and maceral controls on porosity in overmature marine shales in China and the United States. Shale from Ordos Basin in China was also selected as an example of overmature transitional shale for maceral comparison. Organic petrology techniques were used to identify maceral types and describe morphological features in detail; scanning electron microscopy techniques were then used to document the abundance and development of pores within macerals. Helium measurement, mercury intrusion capillary pressure, and $\mathrm{CO}_{2}$ adsorption were especially applied to quantify the pore structure of Wufeng-Longmaxi shale from Sichuan Basin in China. The vitrinite reflectance equivalent of the studied overmature samples is $\sim 2.4 \%$. The macerals within the studied marine shales are composed mainly of pyrobitumen and zooclasts. At this maturity, pyrobitumen develops abundant gas-related pores, and their volume positively correlates to gas content. Three types of pyrobitumen and its related pore structure are characterized in Wufeng-Longmaxi shales. Zooclasts contribute to total organic carbon (TOC) content but little to porosity. When the TOC content is above $1.51 \%$ in WufengLongmaxi samples, the TOC content positively correlates to quartz content. Organic matter strongly controls micropore development. Pores of diameter $\sim 0.5 \mathrm{~nm}$ provide a significant amount of micropore volume. Clay mineral and quartz contents control micro- and macropore increments in organic-lean shales. MICP results indicate that pores within 3-12 nm and 900$2500 \mathrm{~nm}$ account for a major contribution to pore volume obtained. Determining the proportions of pyrobitumen to zooclasts within the total organic matter in pre-Devonian organic-rich marine shales is important in predicting porosity and gas storage capacity in high-maturity shales.
\end{abstract}

\section{Introduction}

Elucidating the pore network and its evolution in gas shales is a key topic in unconventional oil and gas exploration because many studies have shown that shale pore structure is one of the most important factors controlling gas storage capacity ([1]; Jarvie et al. 2007; [2-13]). Shale pores have been divided into micropore $(<2 \mathrm{~nm})$, mesopore $(2-50 \mathrm{~nm})$, and macropore $(>50 \mathrm{~nm})$ based on pore size [14]. Researchers also divided pores into interparticle pore, intraparticle pore, and 
organic matter $(\mathrm{OM})$ pore based on pore types and position [15-20]. Previous studies suggest that various controlling factors influence the abundance of pores, such as total organic carbon (TOC) content and mineralogy $[5,16,17$, 21-23]. Quantitative assessments of pore volume and pore size distribution analyzed by scanning electron microscopy (SEM) imaging and gas adsorption techniques revealed that OM porosity is a significant component of the pore networks of shales [3, 5-7, 24-26]. Most researchers concluded that TOC content has a positive relationship with porosity in shales [4, 16, 18, 27-29]. For example, Mastalerz et al. [16] suggest that $\mathrm{OM}$ contributes micropores to total porosity in organic-rich marine shales. Also reported in the literature are cases that do not show a strong TOC-porosity correlation perhaps because of the presence of a significant inorganic porosity fraction $[15,18,23,30-36]$. A growing number of researchers have suggested that porosity is influenced by mineralogy and rock fabric [17, 31,37]. For example, Mastalerz et al. [16] observed that total porosity increases with clay and quartz content and decreases with carbonate content. Ji et al. [38] and Chen et al. [39, 40] concluded that the biogenic quartz in marine shale was typically accompanied by abundant pores, whereas the quartz in marine-continental transitional shale or continental shale had little influence on the pore structure. Milliken et al. [17] proposed higher clay content may allow the collapse of OM pores and interparticle pores, especially for deeply buried shales that have undergone immense compaction [40].

The effects of thermal maturation on porosity have recently attracted more attention because of the growing recognition that the porosity of $\mathrm{OM}$ is a function of thermal maturity $[4,16,18,27,29,41,42]$. For example, Curtis et al. [4] used focused ion beam milling combined with scanning electron microscopy (FIB-SEM) techniques to investigate the organic porosity within Woodford shale, finding that secondary organic porosity is absent in samples having vitrinite reflectance $\left(\mathrm{VR}_{\mathrm{o}}\right)$ values $<0.9 \%$ but does occur in samples having $\mathrm{VR}_{\mathrm{o}}>1.23 \%$. Mastalerz et al. [16] examined the evolution of porosity with maturation in a suite of five New Albany Shale samples spanning a maturity range from immature $\left(\mathrm{VR}_{\mathrm{o}}=0.35 \%\right)$ to postmature $\left(\mathrm{VR}_{\mathrm{o}}=1.41 \%\right)$, observing that total porosity and total pore volume show a significant decline from immature to late mature and then regain higher values in the postmature sample. However, their data were limited to shales having $\mathrm{VR}_{\mathrm{o}}$ values $<1.41 \%$. That study suggests that porosity change with maturity is the response to oil and gas generation. In addition, there is a growing awareness that different macerals have different pore characteristics and that the evolution of porosity with maturity is maceral-dependent [43-47]. A maceral is an organic component of coal and shale. The type, amount, and origin of macerals in shales are a function of their depositional environment. For example, the liptinite group includes oil-prone macerals containing compounds of a mainly aliphatic nature, and upon thermal evolution, they produce hydrocarbons $[48,49]$. The vitrinite group originates from lignin and cellulose, partly from tannins of the woody tissues of plants [47, 50-52], and is considered to be gas-prone. Liu et al. [45] studied maceral evolution in New
Albany Shale (NAS) as an example of kerogen type II marine shale at the early mature to postmature stage. They show that amorphous organic matter (AOM) and alginite are the dominant organic components in their early mature samples, whereas solid bitumen becomes the dominant OM in samples in the oil window and even higher-maturity stages. They concluded that secondary organic nanopores developed in solid bitumen when oil and gas were generated and expelled. Vitrinite and inertinite did not contribute much to porosity. Haeri-Ardakani et al. [53] discussed OM assemblage in Utica shale samples, consisting of type II marine kerogen (i.e., chitinozoans, graptolite, and liptinite) and migrated bitumen. They also concluded that bitumen is the only organic fraction that contributed to total porosity for Utica shale samples in the oil window but not for samples in the dry gas window [43].

Pore structure is constantly changing under the combined effect of the thermal transformation of OM, and the major control on shale pores at the overmature stage (range from $1.5 \%$ to above $2.5 \%$ ) remains unclear. The characterization of porosity of various macerals in marine shale has mostly been done on mature rocks where various macerals are present and easy to identify [45, 47, 53]. However, researchers also have different opinions on maceral identification in overmature shales. For example, Liu et al. [45] proposed that AOM and alginite in New Albany marine shales disappeared at the late mature stage. Hu et al. [54] identified two types of alginite in overmature Longmaxi marine shales in China. Besides, much less is known about the influence of macerals on pore characteristics in high-maturity shales. It remains unclear how the original OM evolves and how secondary products influence the overall porosity at the overmature stage. Some researchers concluded that zooclasts also contribute to porosity and, as such, are an important component in gas storage $[55,56]$, but how zooclasts evolve during maturation and how they differ from other macerals remain unclear. In general, detailed organic petrology studies are limited to high-maturity shales.

In this study, Late Ordovician to Early Silurian overmature shales in China and the U.S. were chosen for petrographic and porosity characterization. Most representative samples come from the most productive marine shales in Sichuan Basin in China (Figure 1), which have reached a maturity equivalent to $\mathrm{VR}_{\mathrm{o}}=\sim 2.3-3.0 \%$ [57-61]. Many economically important high-maturity gas shales are of preSilurian age, and they are characterized as a different mineral and maceral composition which controls pore development [62-64]. Specifically, this investigation is aimed at studying (1) the pore type characterization in the overmature stage. Both the marine and transitional shales are selected for maceral comparison. Our study uses a combination of optical microscopy and SEM to characterize OM in postmature shales. Optical microscopy can evaluate the color, reflectance, and morphology of OM and can identify maceral types [44, 65]. SEM observations of ion-milled argon allow us to examine nanometer-scale OM-hosted pores in shales $[2,66,67]$. This investigation is also aimed at studying (2) the pore structure characterization in overmature marine shales and major control factors on porosity. We chose $\mathrm{CO}_{2}$ gas 

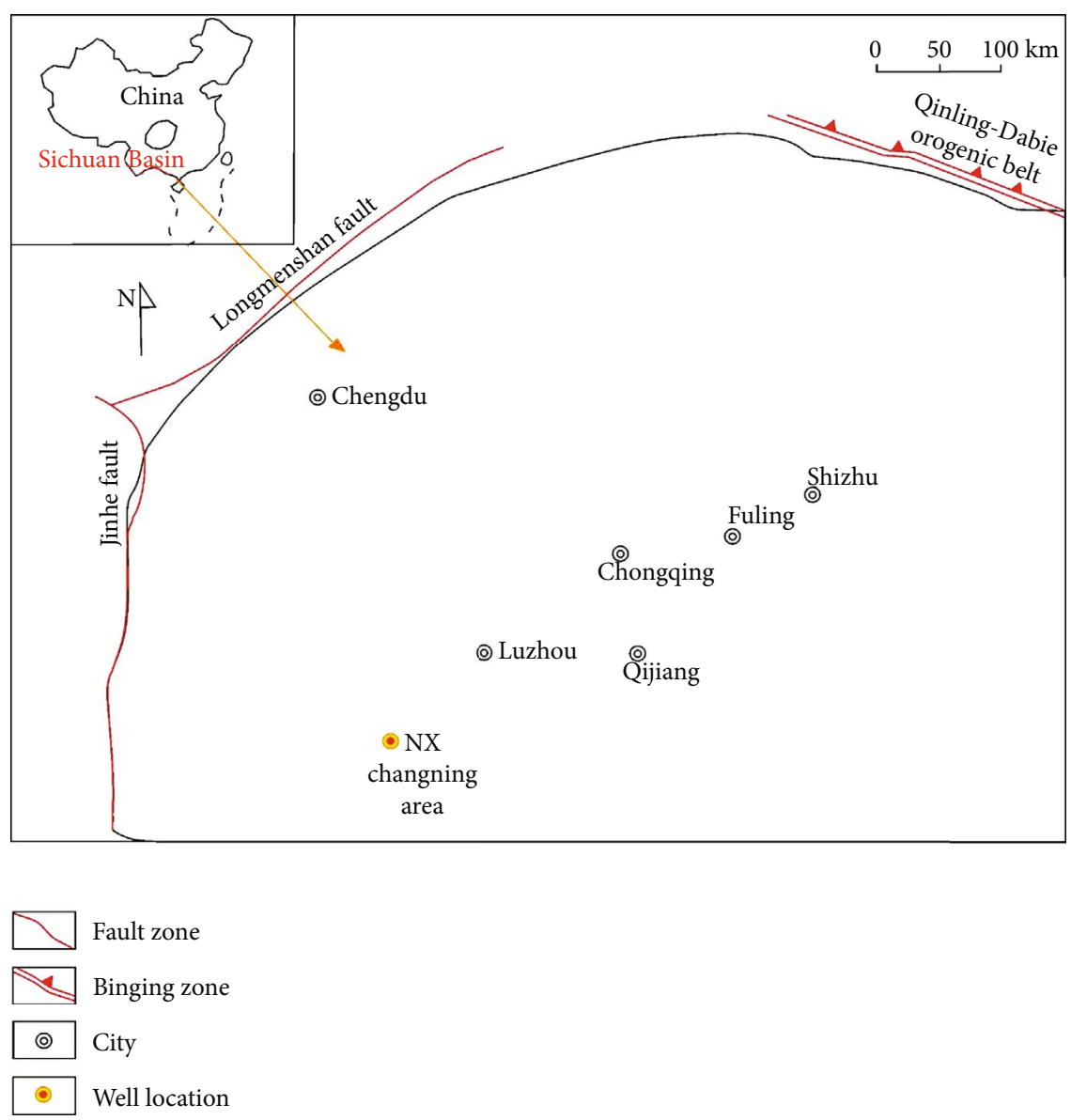

FIGURE 1: Geological background and core location (well NX is marked as a colored dot in Changning area) in Sichuan Basin in the southwest of China. Sichuan Basin is surrounded by the orogenic belt around Longmen Mountain, Jinhe Mountain, and Qinling Mountain. The study region is located in the southwest region of Sichuan Basin.

adsorption and mercury injection capillary pressure (MICP) analysis as tools of this study. Our study contributes to an understanding of maceral types and the control of SEMdetectable pores in different OM types in typical overmature pre-Paleozoic shales and aids in evaluating the pore structure control factors, occurrence, and storage of gas in overmature shale reservoirs.

\section{Samples and Experimental Method}

To characterize OM populations and pore structures, we used Wufeng-Longmaxi shale samples interpreted as being overmature from sedimentary basins in China. WufengLongmaxi shales are from Sichuan Basin located in the southwest of China (Figure 1). Samples N1 and N12 were selected from a drilled core in Changning County, Sichuan Basin (Figures 1 and 2). The samples came from an interval of 2481 to $2576 \mathrm{~m}$ in depth, covering the Late Silurian to Early Ordovician time period (Table 1). Shales cover the gas-productive Wufeng-Longmaxi Formation. These sediments have been deposited on a deep-sea continental shelf and were interpreted to be overmature marine shales [34, $55,61,68-70]$. Detailed sample information of WufengLongmaxi shale is listed in Table 1.
Additional overmature shales of similar age and maturity from basins in China and the U.S. were also selected only for maceral comparison with Wufeng-Longmaxi shales. Two of them are also marine shales, and the other is marinecontinental transitional shale. Marine shales include Utica shale and Xiuwu shale. Ordos shale belongs to transitional shale. The sample TRA-10 is an example of Early Silurian Utica shale from Appalachian Basin in the U.S. Utica shale is one of the most important gas-producing formations in North America [43, 53, 71-73]. A sample from Xiuwu Basin is characterized as an overmature marine shale deposit at the Ordovician time period [74]. Xiuwu shale is expected to have the highest maturity among marine shales. A shale sample from Ordos Basin is an example of a marine-continental transitional shale deposit in Carboniferous [75-77].

2.1. TOC, XRD, and Porosity Analysis of Wufeng-Longmaxi Shale. The TOC content and mineralogical composition were analyzed in the State Key Laboratory of Petroleum Resources and Prospecting at the China University of Petroleum in Beijing. The TOC contents of the shale samples were measured using a Leco CS230 carbon/sulfur analyzer. Samples were crushed to powder $<100$-mesh size, and then 1 to $2 \mathrm{~g}$ samples were pyrolyzed up to $540^{\circ} \mathrm{C}$. Samples were crushed to 300 mesh size for X-ray diffraction (XRD) analysis using a Rigaku 


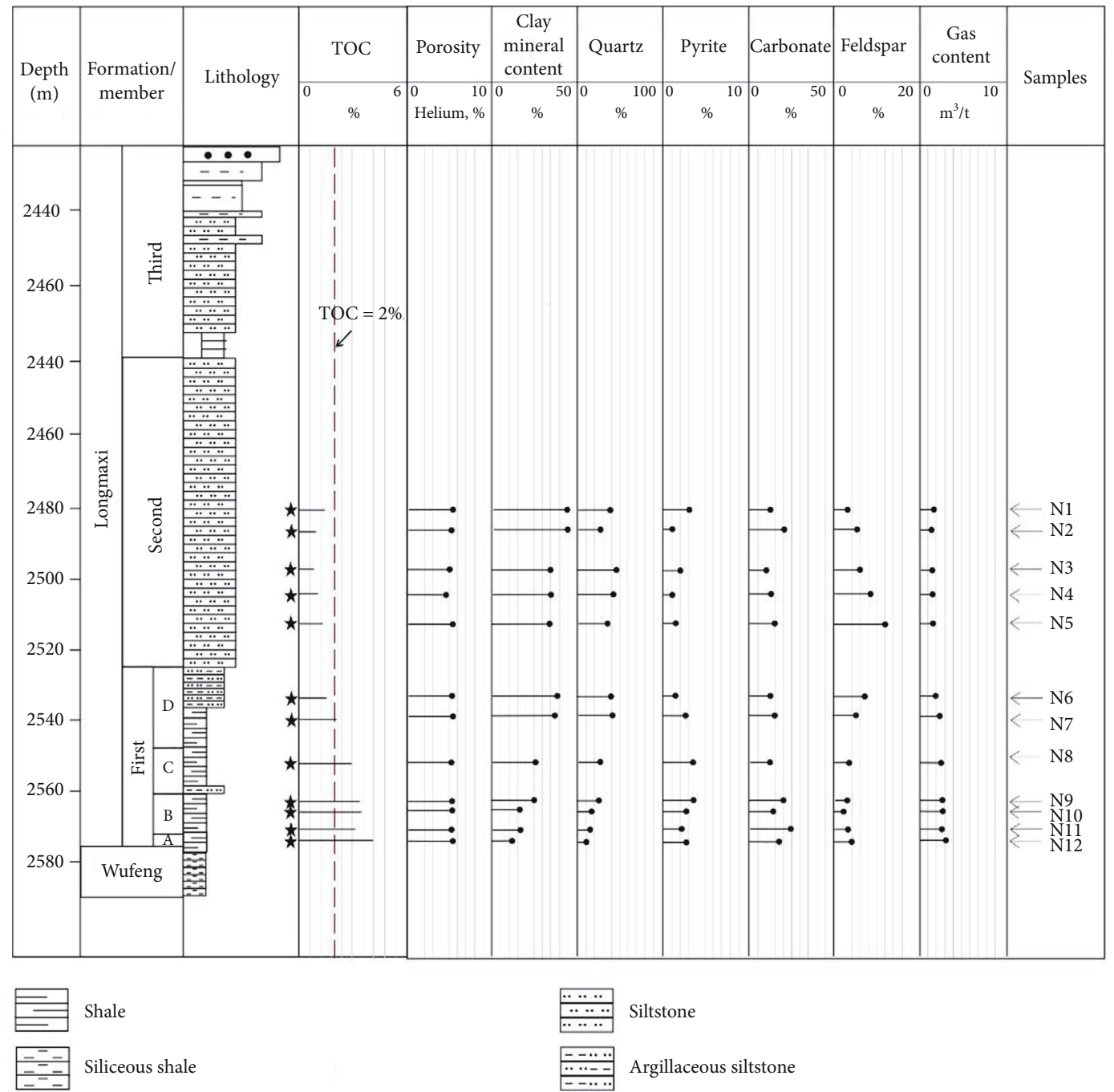

FIgURe 2: Compositional analysis, total organic carbon (TOC) content, helium porosity, and gas content of selected Wufeng-Longmaxi shale samples (N1 to N12) at different depths.

$\mathrm{D} / \mathrm{max}-2500 \mathrm{PC}$ diffractometer at $40 \mathrm{kV}$ and $30 \mathrm{~mA}$. Crushed samples were mixed with ethanol, hand-ground, and then smear-mounted on glass slides. They were further scanned from $2^{\circ}$ to $70^{\circ}$ at a step of $0.02^{\circ}$ and 2 -second step time at room temperature.

The pore structure measurements were performed at Renqiu Jiechuang Petroleum Technology Corporation. Combined MICP and $\mathrm{CO}_{2}$ adsorption were applied to quantify pore structure for different pore sizes. The pore size classification in this study follows the International Union of Pure and Applied Chemistry [78] and other recent pore studies (e.g., [79-81]).

Low-pressure gas adsorption measurements with carbon dioxide $\left(\mathrm{CO}_{2}\right)$ were conducted on a Micromeritics ASAP2020 apparatus. The shale samples were crushed to 60mesh size $(180 \mu \mathrm{m})$. Detailed procedures could be found in Mastalerz et al. [16]. $\mathrm{CO}_{2}$ gas adsorption was used to characterize micropores $(<2 \mathrm{~nm}$ in diameter). The density functional theory (DFT) $[82,83]$ method was used to calculate the specific surface area and pore size distribution based on the adsorption curve.
Mercury intrusion data were collected on a Micromeritics Autopore 9520 instrument. The mercury pressure increases from 0 to $400 \mathrm{MPa}$. Pore size distribution was determined using the Washburn equation [84]. Pore throat size ranging between $3 \mathrm{~nm}(0.003 \mu \mathrm{m})$ and $3 \times 10^{5} \mathrm{~nm}$ $(300 \mu \mathrm{m})$ was characterized. The mercury injection and withdrawal capillary curves were used to predict the behavior of fluids during pressure changes in reservoirs. Pore size distribution can be displayed as cumulative or log differential curves of pore volume or surface area. The log differential curves $(d V / d \log D$ or $d S / d \log D)$ are widely used for comparing relative pore volumes and characteristics of pores $[65,85]$.

Total porosity measurements were carried out with ULTRAPORE-300 using a helium expansion method. The gas contents of the shale samples were analyzed by the Research Institute of PetroChina Southwest Oil \& Gasfield Company. They were measured using direct methods, according to a procedure similar to the USBM method [86], and indirect methods following the sorption isotherm procedure described in the literature $[87,88]$. 
TABLE 1: Lists of Wufeng-Longmaxi shale samples from Sichuan Basin and their depths, porosities, total organic carbon (TOC) contents, and mineral contents. Gas contents are also included. Gas contents include lost gas, desorbed gas, and remaining gas.

\begin{tabular}{|c|c|c|c|c|c|c|c|c|c|}
\hline $\begin{array}{l}\text { Sample } \\
\text { ID }\end{array}$ & $\begin{array}{l}\text { Depth } \\
(\mathrm{m})\end{array}$ & $\begin{array}{c}\text { TOC (total organic carbon } \\
\text { content, } \%)\end{array}$ & $\begin{array}{c}\text { Porosity } \\
\text { (helium, \%) }\end{array}$ & $\begin{array}{l}\text { Clay mineral } \\
\text { content }(\%)\end{array}$ & $\begin{array}{c}\text { Quartz } \\
(\%)\end{array}$ & $\begin{array}{c}\text { Pyrite } \\
(\%)\end{array}$ & $\begin{array}{l}\text { Carbonate } \\
(\%)\end{array}$ & $\begin{array}{c}\text { Feldspar } \\
(\%)\end{array}$ & $\begin{array}{l}\text { Gas content } \\
\left(\mathrm{m}^{3} / \mathrm{t}\right)\end{array}$ \\
\hline N1 & 2481 & 1.23 & 5.23 & 43.0 & 38.3 & 3.1 & 12.5 & 3.1 & 1.62 \\
\hline N2 & 2487 & 0.96 & 4.35 & 46.3 & 27.4 & 1.1 & 20.3 & 4.9 & 1.38 \\
\hline N3 & 2498 & 0.89 & 4.47 & 35.0 & 47.0 & 2.0 & 10.1 & 5.9 & 1.34 \\
\hline N4 & 2503 & 1.07 & 4.22 & 36.6 & 40.7 & 1.1 & 13.5 & 8.1 & 1.42 \\
\hline N5 & 2513 & 1.31 & 4.53 & 34.3 & 36.0 & 1.5 & 16.0 & 12.2 & 1.55 \\
\hline N6 & 2534 & 1.51 & 5.30 & 38.2 & 40.3 & 1.5 & 13.1 & 6.9 & 1.98 \\
\hline N7 & 2540 & 2.15 & 5.25 & 35.6 & 43.9 & 2.6 & 12.6 & 5.3 & 2.33 \\
\hline N8 & 2554 & 2.98 & 5.30 & 26.0 & 55.1 & 3.6 & 12.0 & 3.3 & 2.41 \\
\hline N9 & 2563 & 3.39 & 5.47 & 25.1 & 46.8 & 3.7 & 20.7 & 3.7 & 2.54 \\
\hline N10 & 2567 & 3.52 & 5.67 & 16.2 & 64.8 & 2.7 & 14.3 & 2.0 & 2.61 \\
\hline N11 & 2573 & 3.19 & 5.22 & 15.9 & 54.6 & 2.1 & 24.5 & 2.9 & 2.63 \\
\hline N12 & 2576 & 4.18 & 5.88 & 11.8 & 59.3 & 2.7 & 22.3 & 3.9 & 3.08 \\
\hline
\end{tabular}

2.2. Organic Petrology and Scanning Electron Microscopy (SEM) Analysis. Each core sample was cut into $\sim 2 \times 1.5 \mathrm{~cm}$ fragments. Organic petrology and SEM observations were carried out in the same area; reflected light microscopy was used to identify OM, whereas SEM was used to visualize pores, as well as to evaluate changes in the rock fabric resulting from different mineralogies.

Samples were argon-ion-milled with Gatan 600 DuoMill using a custom-designed sample holder and then observed and analyzed using field emission- (FE-) SEM (Quanta 200F) in low vacuum mode at the China Petroleum Exploration Research Institution. FE-SEM was performed using a Hitachi S-4800 FE-SEM microscope with an accelerating voltage of $1.0 \mathrm{kV}$. Samples were not coated. The analyzed areas were photographed/mapped to enable the subsequent identification of the same OM particles under a microscope. All SEM images were taken under secondary electron imaging mode. Considering the heterogeneity of shales, 60 evenly spaced SEM pictures were taken within the sample to document the morphology and pore development of OM particles. In the same areas where SEM photomicrographs were taken, organic macerals were identified using reflected light microscopy (Leica DFC310 FX) at Indiana University in Bloomington, Indiana, USA. To evaluate the maturity of the samples, the reflectance of graptolite and/or pyrobitumen was measured under reflected white light and oil immersion, with 25 readings recorded.

2.3. Micro-FTIR. Micro-FTIR measurements were performed with a Nicolet 6700 spectrometer connected to a Nicolet Continuum microscope operating in reflectance mode. For micro-FTIR mapping, the smallest aperture size used for the area analysis is $25 \times 25 \mu \mathrm{m}$. Details about instrumentation were presented by Wei et al. [89]. Briefly, Micro-FTIR spectra were obtained at a resolution of $4 \mathrm{~cm}^{-1}$, using a gold plate as a background. The spectra cover a wavenumber range from $650 \mathrm{~cm}^{-1}$ to $4000 \mathrm{~cm}^{-1}$. The OMNIC program was used for spectral deconvolution, curve fitting, and deter- mination of peak integration areas. Reflectance micro-FTIR spectra were subjected to Kramers-Kronig transformation. Peak assignments of spectra were based on Painter et al. $[90,91]$ and Wang and Griffiths [92].

\section{Results}

3.1. Compositional Analysis, TOC, Helium Porosity, and Gas Content of Wufeng-Longmaxi Shale. Twelve WufengLongmaxi samples from one well at different depths were chosen for this study. The analyzed TOC content, mineral composition, and helium porosity results of WufengLongmaxi shale (N1 to N12) are presented in Table 1. Relationships between depths and those geochemical parameters are shown in Figures 2 and 3. In the well, the TOC content decreases upward in the section, ranging from $4.18 \%$ to $0.89 \%$, and the gas content has a similar decreasing trend with shallower depths. Mineralogically, the quartz and clay mineral contents are the main components, accounting for $\sim 46 \%$ and $\sim 30 \%$, respectively, in the studied samples. The average value of carbonate content is $\sim 16 \%$, and pyrite and feldspar contents are minor (a few percent, on average). Samples N1 to N7 at shallower depths have relatively lower quartz and carbonate contents but higher clay mineral content compared to samples at greater depths. Quartz content exhibits a weak positive relationship with TOC content $\left(R^{2}=0.69\right)$ for all twelve studied Wufeng-Longmaxi shales (Figure 3(b)). However, quartz content is obviously correlated with TOC content in shale with clay content $<38 \%$ (approximately equal to the mean value of clay content in the twelve studied samples), while no obvious relationship is shown with increasing TOC in shales with high clay content $(>\sim 35 \%)$. Furthermore, clay content shows an obvious negative relationship with TOC content $\left(R^{2}=0.84\right)$. The helium porosity of the samples was between $4.22 \%$ and $5.88 \%$. The result shows that the gas yield ranged from 1.34 to $3.08 \mathrm{~m}^{3} / \mathrm{t}$ of rock. Overall, the TOC content, helium porosity, quartz and carbonate contents, and gas content increase 


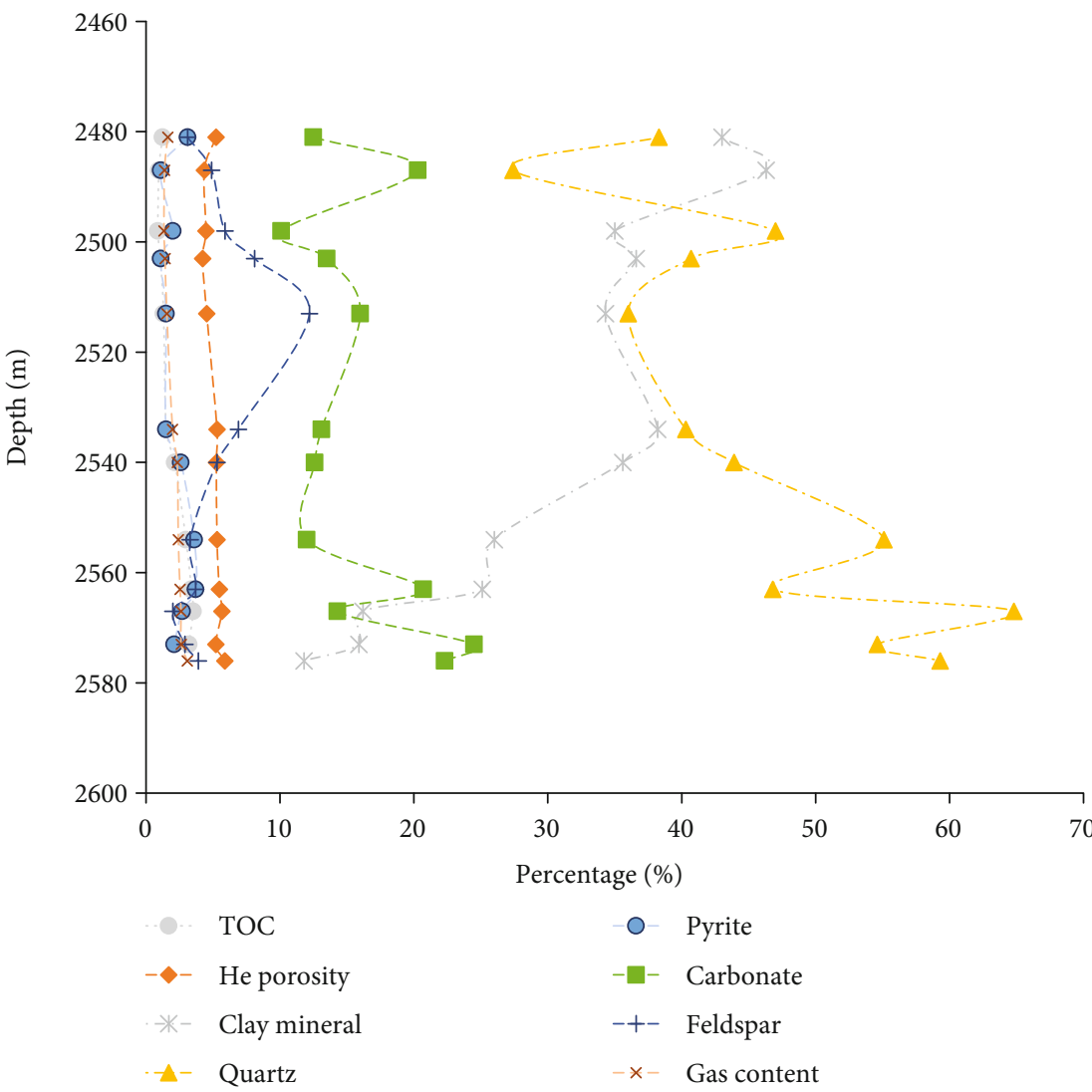

(a)

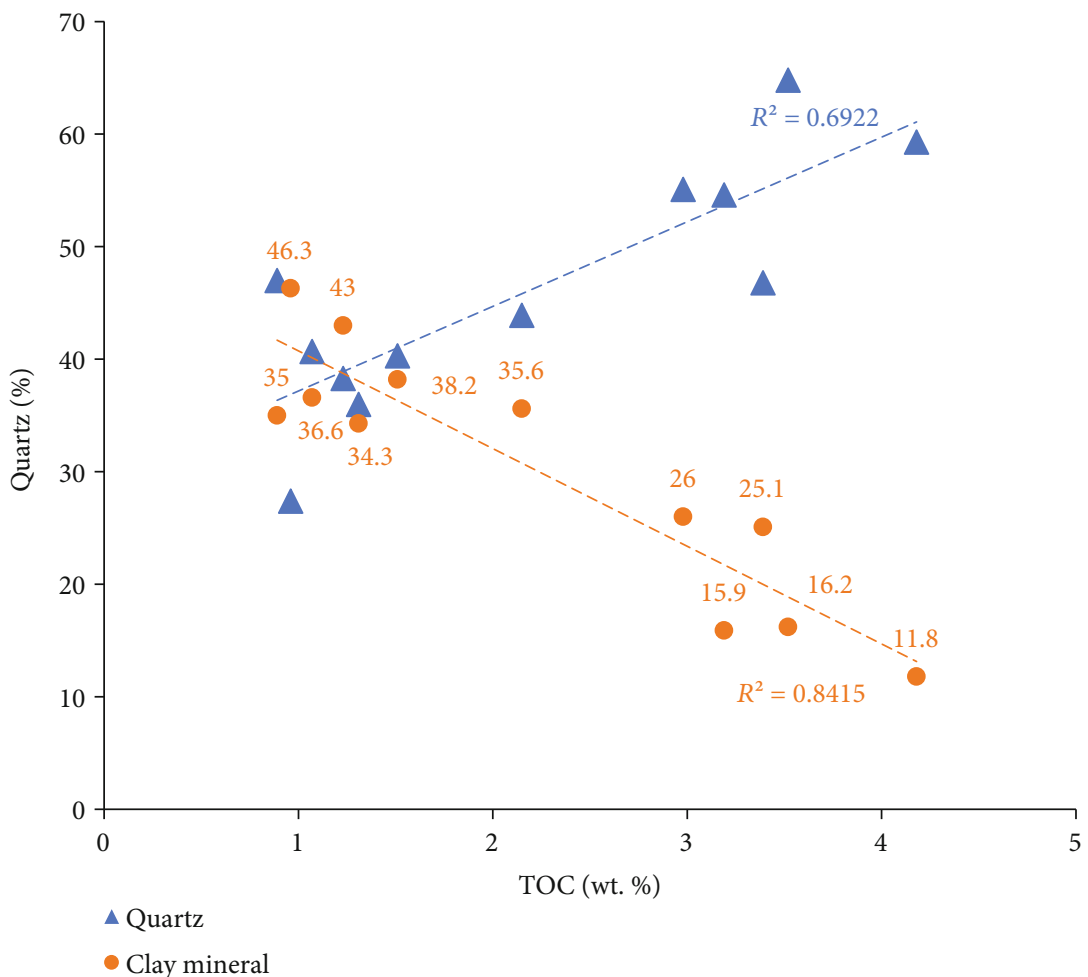

(b)

FIGURE 3: (a) Relationship between depth and total organic carbon (TOC) content (\%), mineral content (\%), helium porosity content (\%), and gas content $\left(\mathrm{m}^{3} / \mathrm{t}\right)$ of Wufeng-Longmaxi shales. (b) Crossplot of quartz content vs. TOC content. Crossplot of clay mineral content vs. TOC content. The marked numbers are contents (\%) of clay minerals of Wufeng-Longmaxi shales. 
with depth, especially when depth is at $2540 \mathrm{~m}$ and deeper. The measured mean reflectance of pyrobitumen in sample $\mathrm{N} 9$ at $2573 \mathrm{~m}$ is $2.22 \%$, and three equations were used to calculate equivalent vitrinite reflectance $\left(\mathrm{VR}_{\mathrm{o}}\right):(1) \mathrm{VR}_{\mathrm{o}}=($ $0.618 \times \mathrm{BR}_{\mathrm{o}}($ bitumen reflectance $\left.)\right)+0.4=1.77 \% \quad$ [93]; (2) $\mathrm{VR}_{\mathrm{o}}=\left(\mathrm{BR}_{\mathrm{o}}+0.41\right) / 1.09=2.41 \%$ [94]; and (3) $\mathrm{VR}_{\mathrm{o}}=\left(\mathrm{BR}_{\mathrm{o}}\right.$ $-0.059) / 0.936=2.31 \%$ [95]. Even though the values obtained range in amounts, they all indicate a postmature stage and dry gas window.

\subsection{Organic Petrology and Maceral Morphology}

3.2.1. Wufeng-Longmaxi Shale. Reflected light microscopy and SEM were used to identify and describe different macerals (Figures 4(a) and 4(b)). Photomicrographs of the same areas at the same scale were taken using those two methods (Figures 5 and 6). Under incident white light, a large number of gray structureless OM were observed in WufengLongmaxi shale; those small OM particles (less than $10 \mu \mathrm{m}$ ) are pyrobitumen. Some pyrobitumens occur as speckles disseminated in the shale matrix (Figures 4(a), 4(b), and 5(d)), and some occupy interparticle pores and microfractures (Figures $4(\mathrm{c})$ and $4(\mathrm{~d})$ ) or are present inside zooclasts and mineral grains (Figures 4(e) and 4(f)). We divided pyrobitumen into three types depending on morphology and pore distribution within the particle. The most abundant type is pyrobitumen I, which has no specific shape and fills in intergranular pores and cracks of minerals (Figures 4(c)-4(f)). Occasionally, larger pieces (several micrometers in size) of pyrobitumen (type II) were also observed (Figures $4(\mathrm{~g})$ and 4(h)). Pyrobitumen II featured an intact shape, which does not distribute around microfractures nor surround minerals. Their shapes are not fixed due to compaction and other effects, with diameters ranging from $1 \mu \mathrm{m}$ to more than $10 \mu \mathrm{m}$. They have clear edge outlines. Pyrobitumen III featured a unique surface different from types I and II. The surface is not smooth but displays uniform pellets inside (Figures 4(i) and 4(j)). Pellets are easily recognized under SEM pictures. This OM is composed of small aggregates of quasispherical bacteria. The diameters of the pellets range from 300 to $400 \mathrm{~nm}$. Affected by compaction, some pellets are flattened to form flat spheres.

Other organic components are fragments of structured zooclasts, including graptolite and chitinozoan (Figures 5(a)$5(\mathrm{~d})$ ). The graptolite fragments are grayish-white under reflected light and are characterized by biological morphologies with sharp outlines. Commonly, they are stacked or are forming laminae with a fibrous or threadlike structure (Figures 5(a), 5(b), and 6(a)-6(d)). Void space in these graptolite fragments could be filled with carbonates or quartz. Chitinozoan fragments generally have a segment or scalene shape (Figures 5(c), 6(e), and 6(f)), with a chamber confined by the cell wall. Most zooclast particles seem to be filled with minerals, and OM remains only along the edges. WufengLongmaxi shale samples have the same maceral types at different depths, but the total OM content and relative proportions of pyrobitumen and zooclasts vary. Sporadically, some bodies similar in form to acritarchs could also be found (Figures 6(g) and 6(h)). An acritarch is a small microfossil of unknown and probably varied biological affinities with varied symmetry, shape, structure, and orientation [96]. It can originate from algae, fungal spores, organic-walled cysts from unicellular protozoa, or spawns of higher organisms. Their central cavity is closed or communicates with the exterior via pores, slitlike or irregular ruptures, or circular openings (Figures 6(g) and 6(h)).

3.2.2. Utica Shale. The measured TOC content of Utica shale TRA-10 is $4.1 \%$. Twenty-five points of graptolite reflectance $\left(\mathrm{GR}_{\mathrm{o}}\right)$ were measured, and the mean reflectance value is $2.32 \%$. The equivalent $\mathrm{VR}_{\mathrm{o}}$ was calculated using the same three empirical equations with Wufeng-Longmaxi shale, and the calculated values are 1.83, 2.50, and 2.41 [93-95], indicating the dry gas window. The measured helium porosity of this sample is $3.95 \%$.

In TRA-10, the dominant maceral is graptolite, which consists of $\sim 95 \%$ of the whole OM. Graptolites are typically oriented in a direction parallel to the bedding plane. Some occur as large pieces $(\sim 20-50 \mu \mathrm{m})$ in the matrix (Figures $7(\mathrm{a})$ and $7(\mathrm{~b})$ ), whereas others are small (a few $\mu \mathrm{m}$ or smaller) and dispersed in the matrix (Figures $7(\mathrm{c})$ and $7(\mathrm{f})$ ). The spindle shape of graptolites can also be observed (Figure 7(e)). In this sample, pyrobitumen is much less common than graptolites and occurs around mineral grains in relatively small particles of $<1 \mu \mathrm{m}$ (Figures 7 (c), $7(\mathrm{~d}$ ), and $7(\mathrm{f})$ ). Framboidal pyrite is common.

3.2.3. Ordos Shale. The measured TOC content of Ordos shale is $2.14 \%$. Twenty-five points of vitrinite were measured, and the mean reflectance value is $1.88 \%$, indicating the sample is at the overmature stage. Different from other overmature marine shales in this study, the OM in Ordos shale is composed of vitrinite and inertinite (Figures 8(a) and 8(b)). The vitrinite and inertinite pieces have no observable organic pores under a microscope.

3.2.4. Xiuwu Shale. In Xiuwu shale, the observed macerals are pyrobitumen and zooclast (Figures $8(\mathrm{c})$ and $8(\mathrm{~d})$ ). Pyrobitumen consists of $\sim 95 \%$ of the whole OM. The measured TOC content is $2.84 \%$, and the mean reflectance value from twenty-five points of pyrobitumen measurements is $3.32 \%$. The equivalent $\mathrm{VR}_{\mathrm{o}}$ was calculated using the empirical equation proposed by Landis and Castaño [94]: $\mathrm{VR}_{\mathrm{o}}=\left(\mathrm{BR}_{\mathrm{o}}+\right.$ $0.41) / 1.09=3.42 \%$, indicating a highly overmature stage.

3.3. Organic Pores Analyzed by SEM. In Wufeng-Longmaxi shale samples, large pores (micrometer in size) were observed in pyrobitumen; they can be round, subround, or irregular in shape (Figures 9(a)-9(f)). The round pores have a spongelike shape and texture (Figure 9(b)). Inside some round pores, two tail-like traces can be seen. Clay minerals generally feature a curved to highly contorted scaly and silk thread laminar structure, whereas brittle minerals had a relatively regular shape and lower brightness $[58,97,98]$. In the studied samples, relatively round and subround pores generally were observed in pyrobitumen surrounding brittle minerals (Figures 9(a)-9(d)). The pyrobitumens having deformed or irregular pores are usually filled inside or occurred near clay minerals having layered or deformed structures (Figures 9(e) 


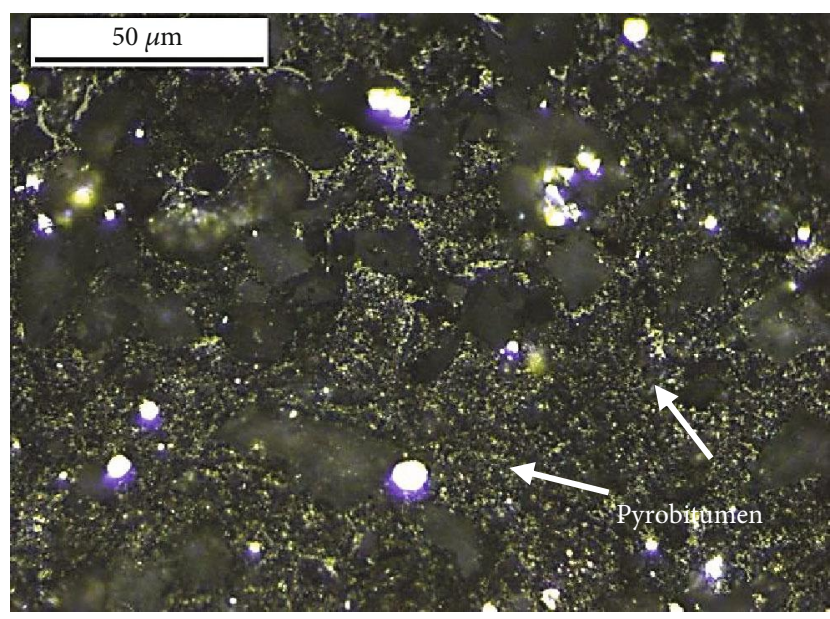

(a)

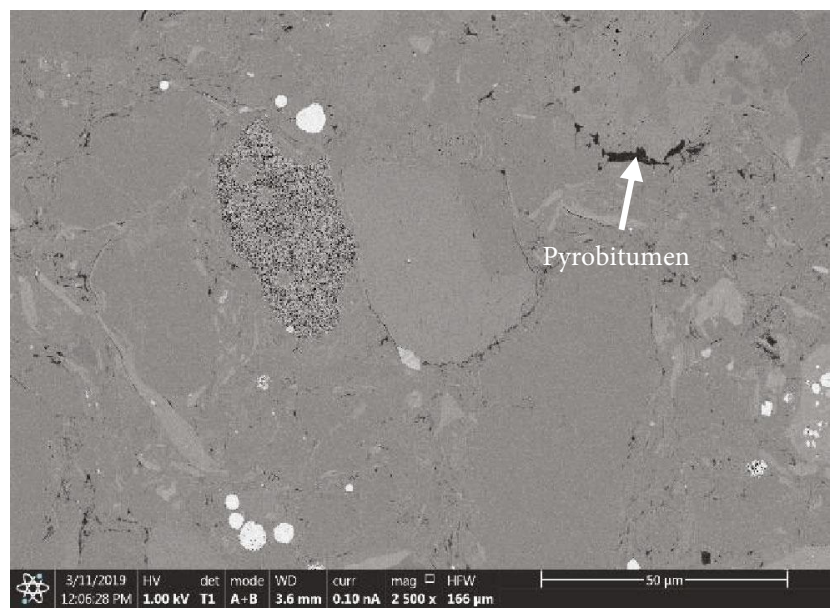

(c)

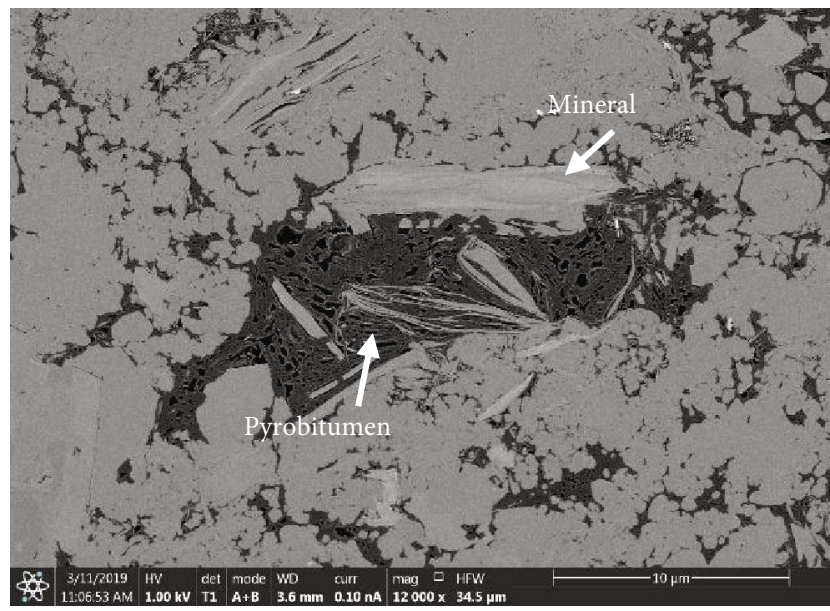

(e)

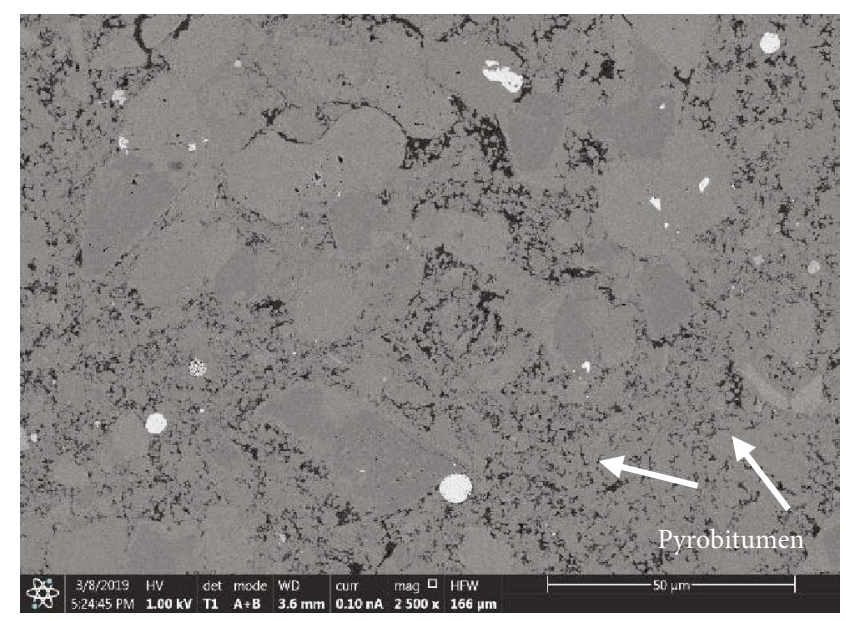

(b)

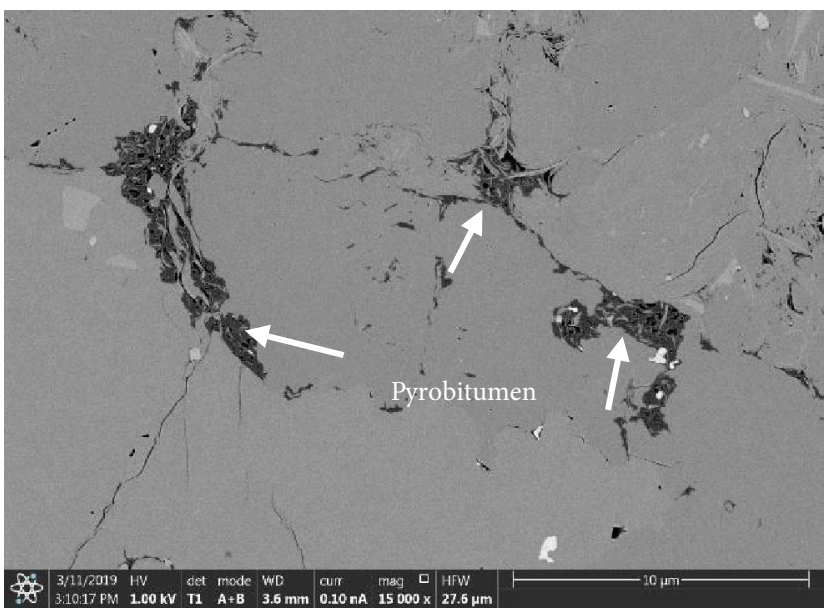

(d)

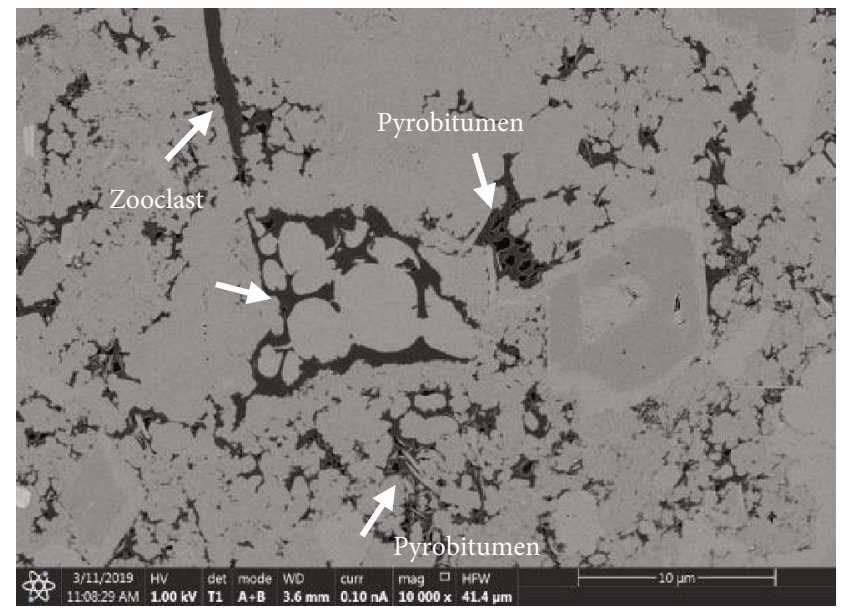

(f)

Figure 4: Continued. 


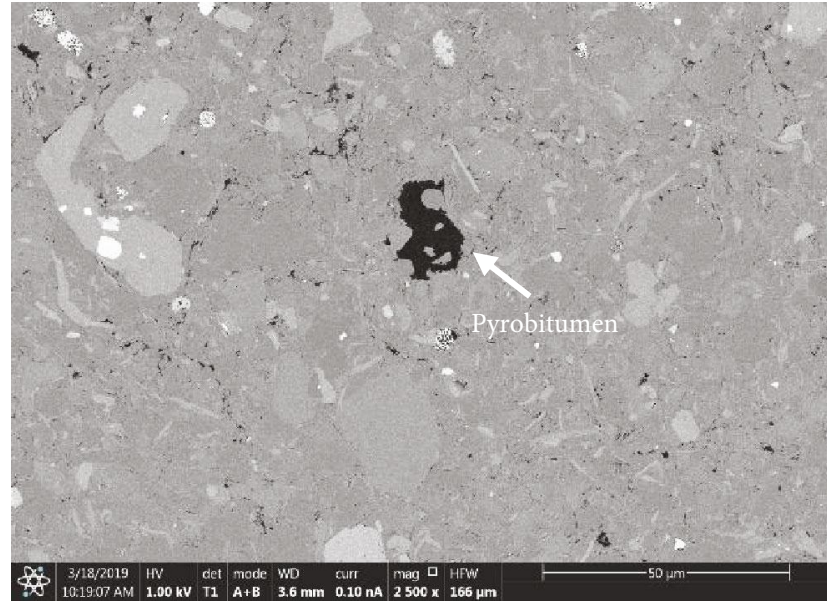

(g)

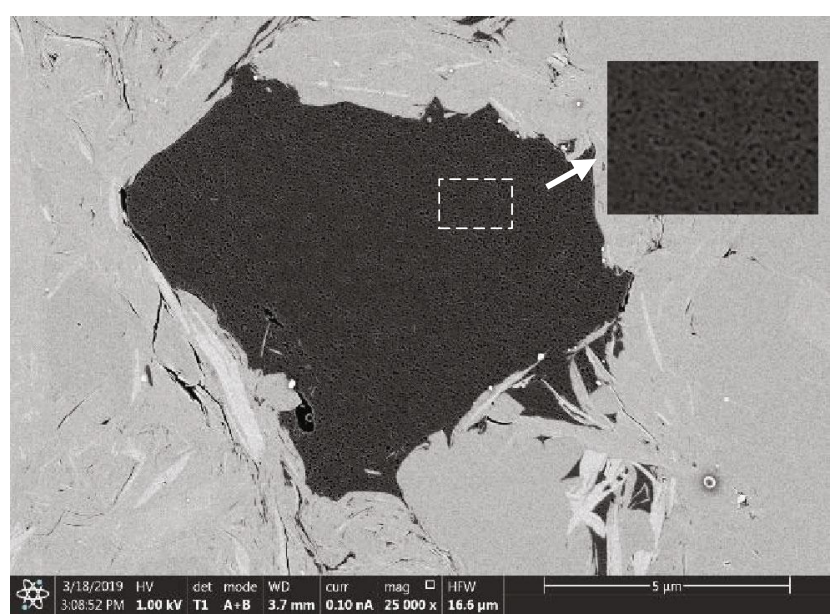

(i)

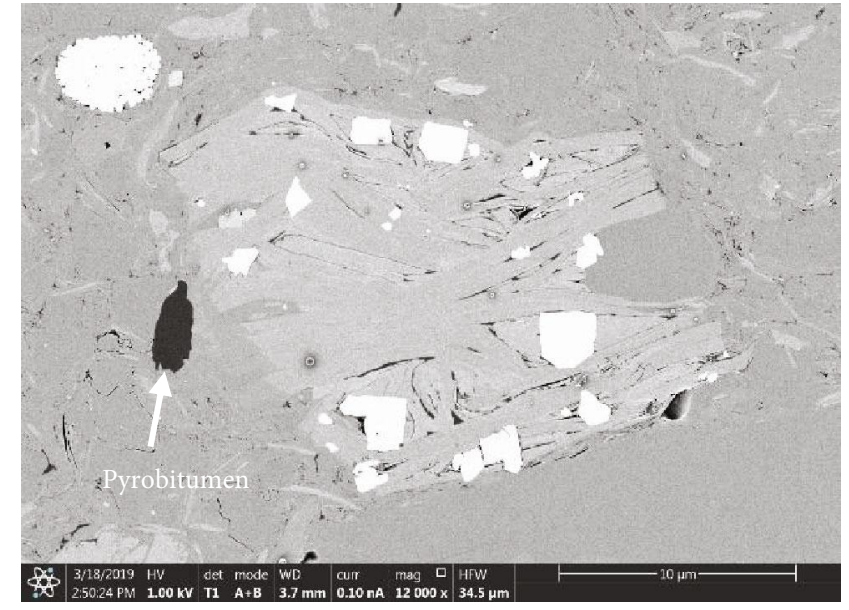

(h)

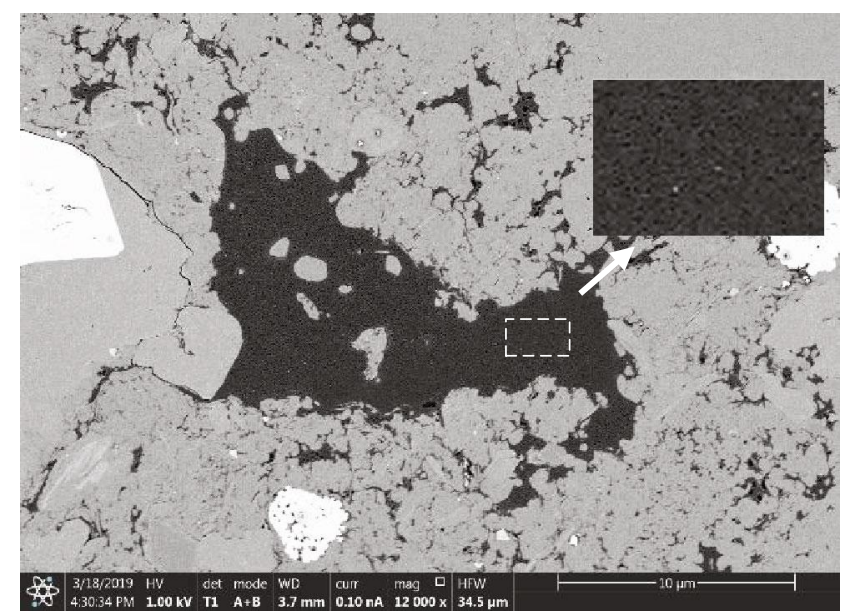

(j)

FIgURE 4: (a) Photomicrographs of groundmass pyrobitumen in Wufeng-Longmaxi shale samples under a microscope in incident white light under oil immersion. (b) Scanning electron microscopy (SEM) of the pyrobitumen disseminated in the shale matrix in the same area as (a). (c, d) Pyrobitumen accumulated in interparticle pores and microfractures. (e, f) Pyrobitumen filling the mineral outline. Zooclast and pyrobitumen distributing along the shale matrix. $(g, h)$ Single large pyrobitumen particle of several micrometers in diameter. The larger rectangles in $(i, j)$ are enlarged areas of the related smaller rectangles. This type of pyrobitumen consists of bacteria-like aggregates.

and 9(f)). Some pyrobitumens had irregular surfaces with abundant pores so that it was difficult to recognize them at a micrometer scale.

Pyrobitumen I has a uniform internal texture, and its pores are uniform or random (Figures $9(\mathrm{a})-9(\mathrm{f})$ ). The pores in pyrobitumen I can be divided into two types: (1) irregular pores with spongy uniform distribution (Figure 9(b)) and (2) circular or elliptical pores (Figures 9(a) and 9(c)-9(f)). The latter has pores of different sizes that coexist. In comparison, pyrobitumen II has no observable pores within OM particles (Figures $4(\mathrm{~g})$ and $4(\mathrm{~h})$ ). Those two types are related to hydrocarbon generation processes at the late stage. Pyrobitumen III displays a different morphology but a homogeneous internal biological structure (Figures 4(i) and 4(j)). This type of pyrobitumen consists of bacteria-like particles; the pores are significantly different from the bubble-like pores in bitumen. The pores are randomly distributed but display a homogeneous internal biological structure.
No pores could be found in graptolite or chitinozoan in the studied samples, even after enlarging images to the nanometer scale (Figures 10(a)-10(d)). It is interesting to note that SEM photomicrographs from the same WufengLongmaxi shale taken on cores without any polishing (Figures 10(e)-10(h); Figure 10(f) is an amplified picture of Figure 10(e); Figure 10(h) enlarges Figure $10(\mathrm{~g})$ ) do show pores in graptolites at a micrometer scale. This observation is in contrast to what we observed in ion-milled samples described in this study (Figures 10(a) and 10(b)).

As described in the methods section, 60 SEM pictures were taken of each sample at different depths from Wufeng-Longmaxi shale. The studied area is the same size on each sample, which allowed us to roughly compare the different maceral contents of the samples. The OM content increases with deeper depth in the studied samples, which is also reflected by the area of dark material in the SEM images of samples (Figures 11(a)-11(h)). Pyrobitumen is 


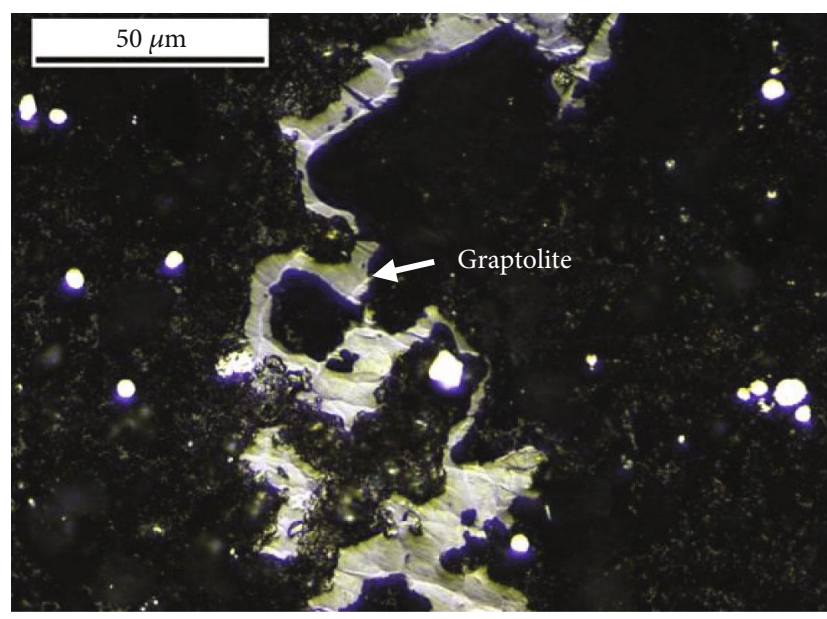

(a)

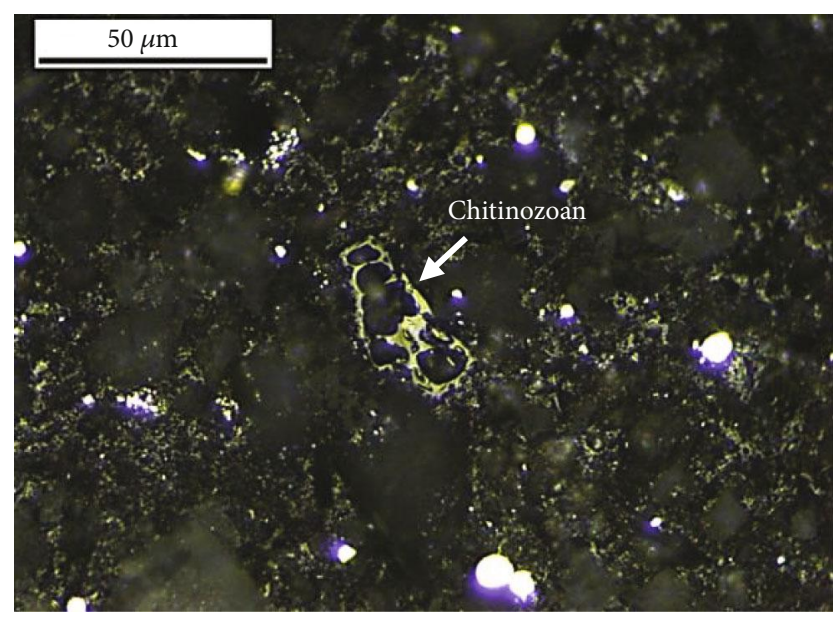

(c)

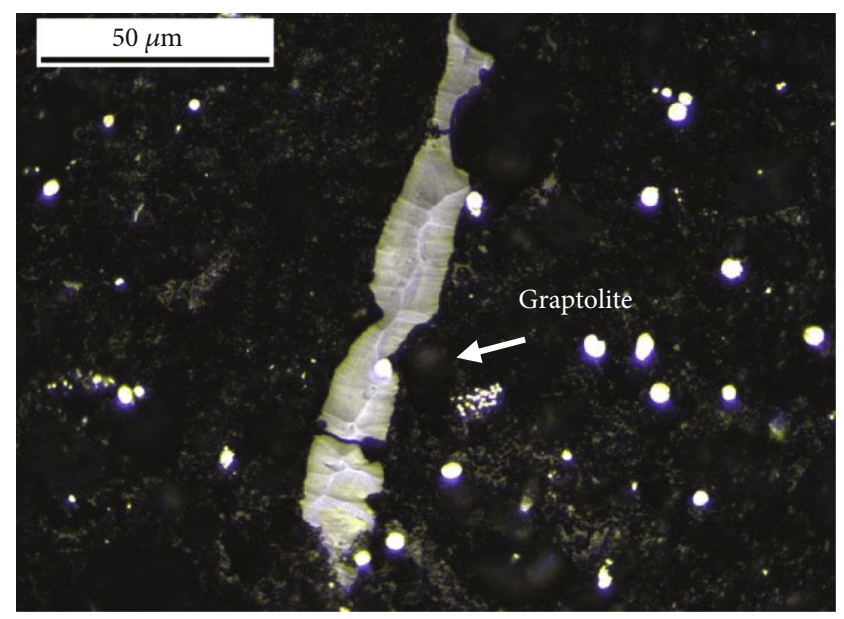

(b)

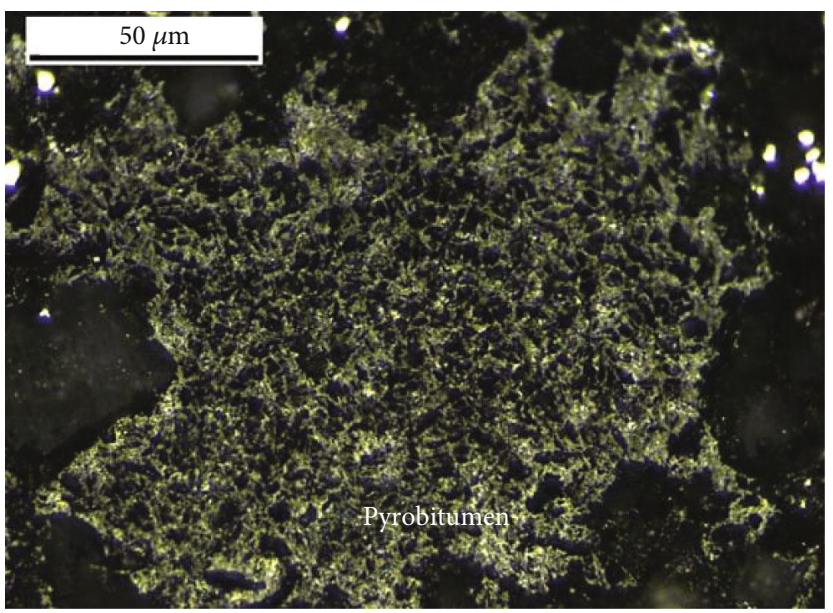

(d)

FIGURE 5: Organic petrography photomicrographs (oil immersion, white incident light) showing typical types and morphology of organic matter in Wufeng-Longmaxi shale samples. (a, b) Graptolite fragment with biological shape and fibrous structure within its cell wall. (c) Chitinozoan fragment with a segment or scalene shape. (d) Pyrobitumen of $\sim 40$ micrometers in size filling the shale matrix.

the dominant maceral in all samples, and it increases in samples from $2567 \mathrm{~m}$ deep and deeper. Zooclast content, including graptolite and chitinozoan, also increases with increasing pyrobitumen content.

For Utica shale, in the SEM analysis at micrometer to nanoscales, most ( 95\%) of the analyzed graptolites had no pores detected under SEM (Figures 12(a)-12(e)). A few pores of irregular and narrow shape were found in some graptolites (Figure 12(f)). For Xiuwu shale, pyrobitumen also is featured as structureless and filling characterization. However, different from Wufeng-Longmaxi shale, those pyrobitumen pieces have already lost abundant OM pores (Figures 8(c) and 8(d)). In addition, the inertinite and vitrinite particles in Ordos shale also featured no observable organic pores inside (Figures 8(a) and 8(b)).

3.4. Pore Characterization Based on $\mathrm{CO}_{2}$ Adsorption and MICP in Wufeng-Longmaxi Shale. Low-pressure $\mathrm{CO}_{2}$ adsorption was applied to characterize the micropore (pore diameter $<2 \mathrm{~nm}$ ) distribution. $\mathrm{CO}_{2}$ adsorption isotherms of the studied shales display similar variations and trends as type I (Figure 13), which is generally characterized by microporous solids [14]. Maximum volumes of adsorbed $\mathrm{CO}_{2}$ range from 0.893 to $2.286 \mathrm{~cm}^{3} / \mathrm{g}$. The volume of adsorbed $\mathrm{CO}_{2}$ increases with TOC content (Figure 13). DFT micropore volumes range from 0.001 to $0.003 \mathrm{~cm}^{3} / \mathrm{g}$, and DFT micropore surface areas range from 3.60 to $9.89 \mathrm{~m}^{2} / \mathrm{g}$ (Table 2).

The strongest adsorption happened in shale samples N8, N9, and N10 of the highest TOC content. Sample N5 adsorbs the least amount of $\mathrm{CO}_{2}$, whereas samples $\mathrm{N} 2$ to $\mathrm{N} 4$ adsorb intermediate volumes. Comparing samples N2 to N5, sample N5 has relatively higher TOC content and feldspar values but relatively the least clay mineral content and quartz content.

The micropore size distribution up to $1.2 \mathrm{~nm}$ was calculated with the DFT model (Figure 14). Pores with diameter $<1 \mathrm{~nm}$ have different $\log$ differential pore volumes. There are three higher $d V / d \log D$ peaks at approximately 0.40 $0.50 \mathrm{~nm}, 0.55-0.60 \mathrm{~nm}$, and $0.80-0.81 \mathrm{~nm}$, which indicate a high abundance of micropore distributions of those pore size 


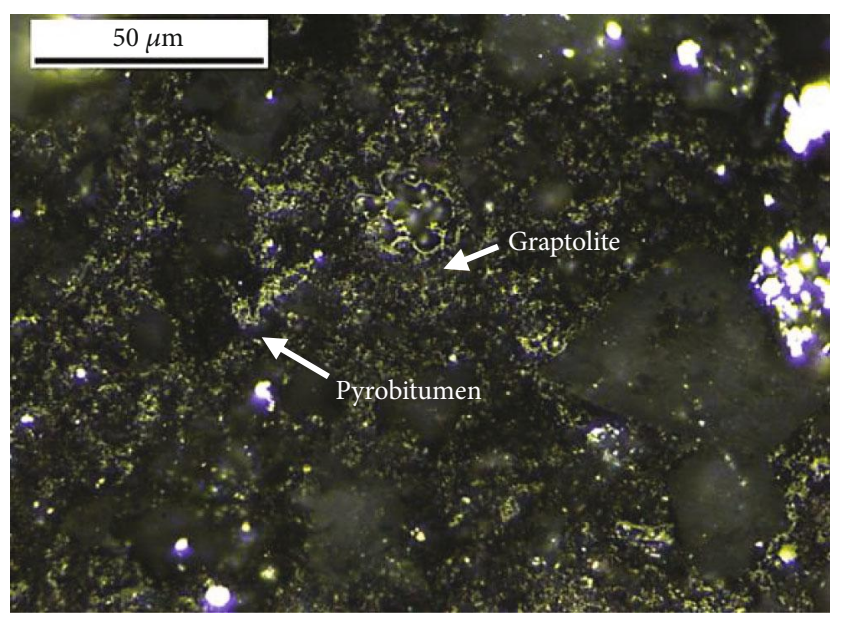

(a)

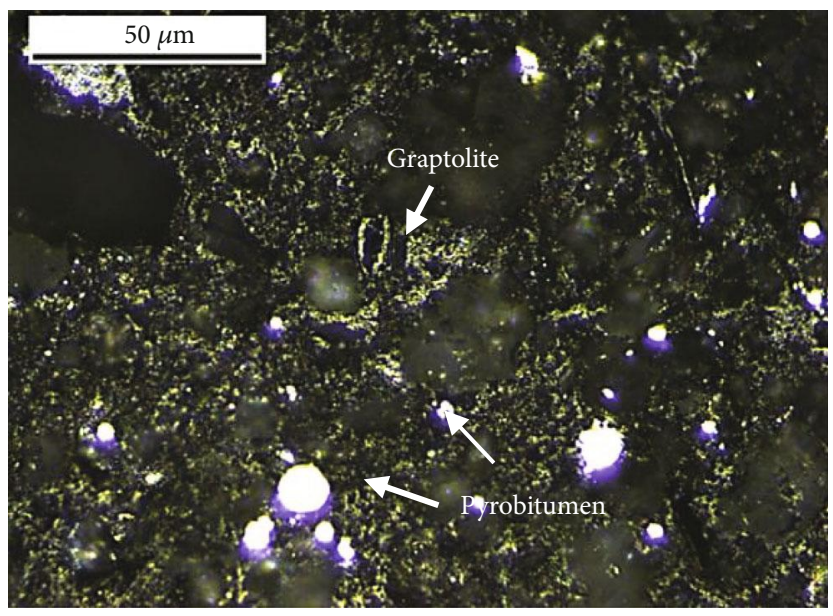

(c)

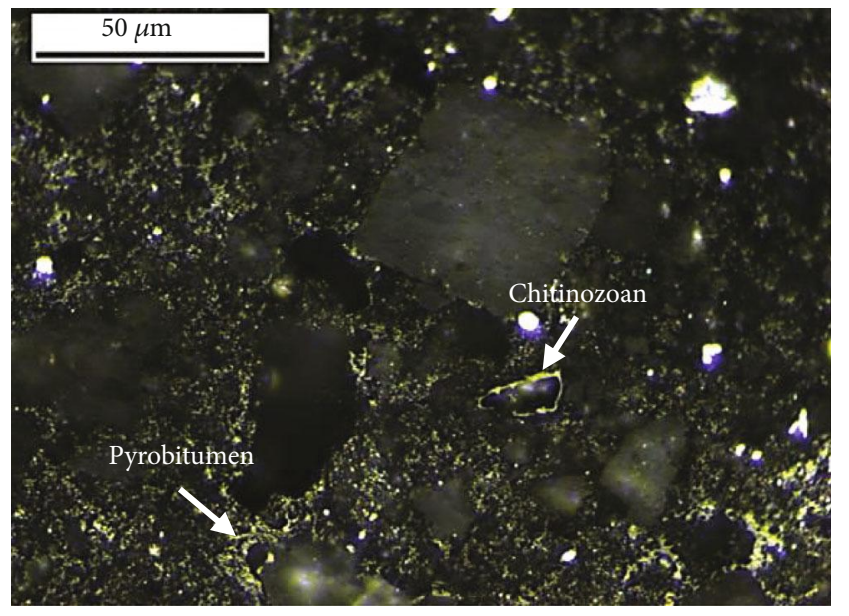

(e)

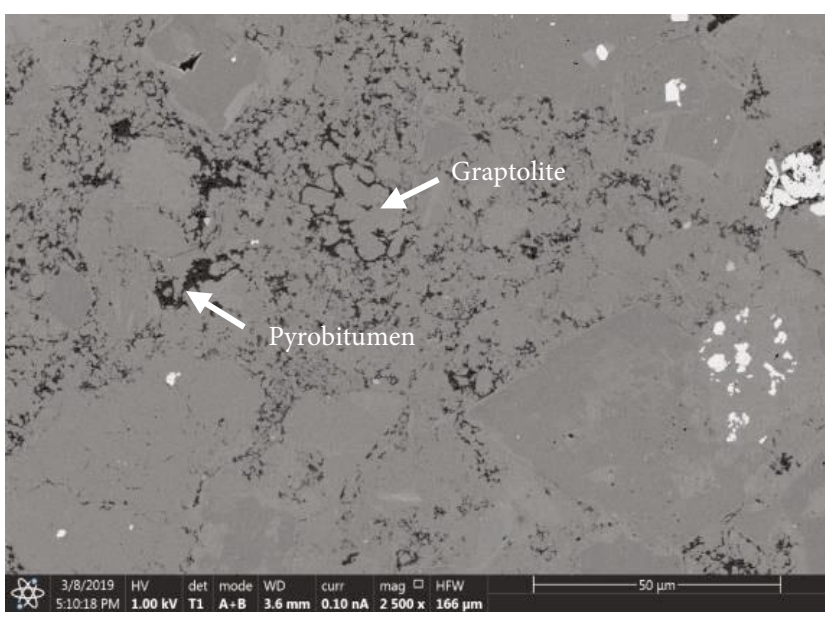

(b)

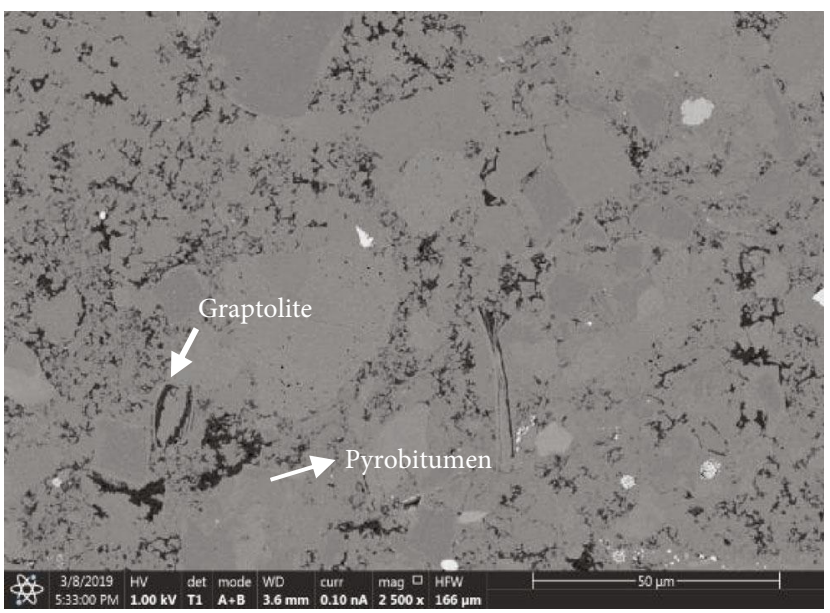

(d)

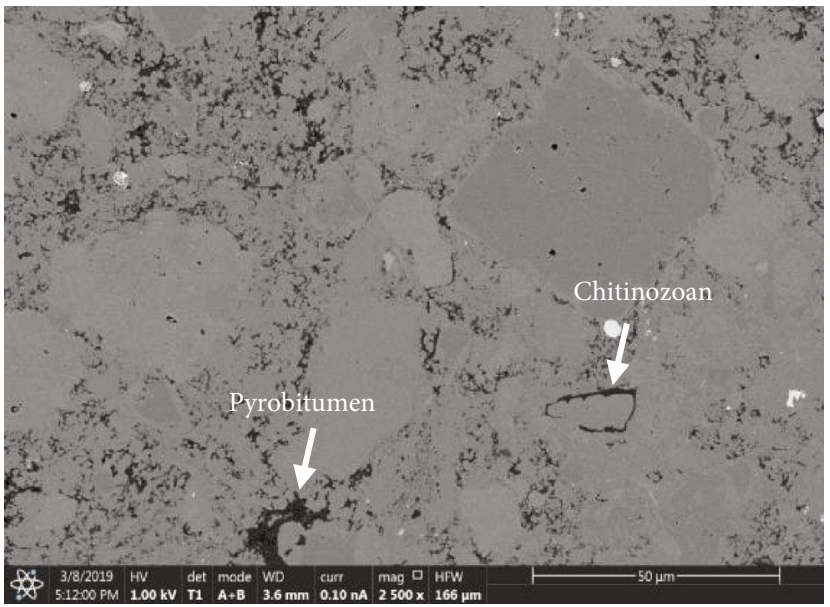

(f)

Figure 6: Continued. 


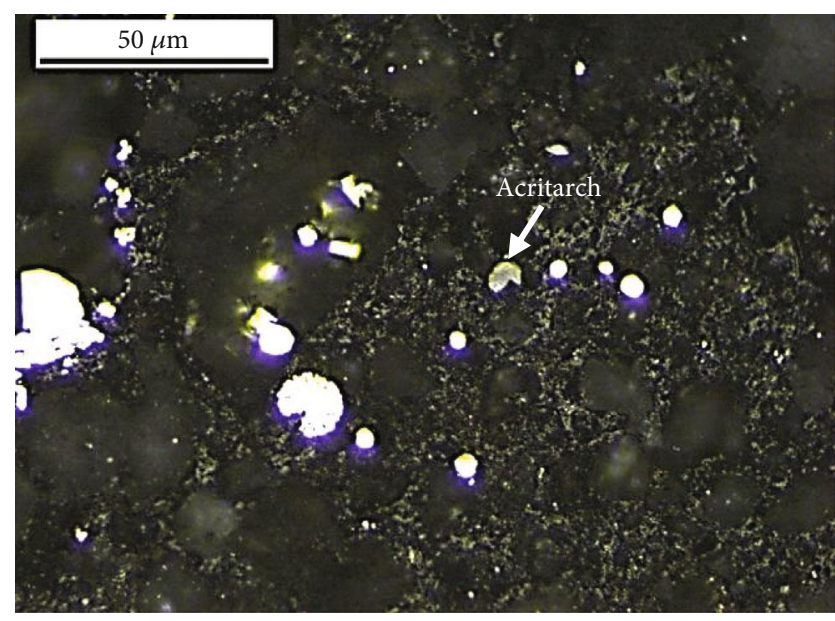

$(\mathrm{g})$

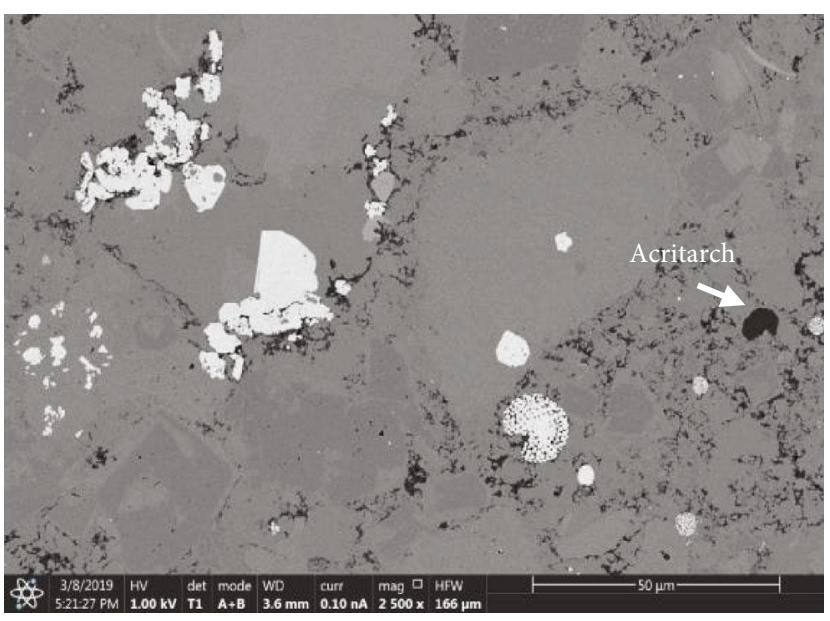

(h)

FIGURE 6: Pyrobitumen and zooclast morphology and distribution under SEM and reflected light microscopy in Wufeng-Longmaxi shale. The pairs $(a, b),(c, d),(e, f)$, and $(g, h)$ show the same areas on four different samples. (a-f) Pyrobitumen occurred as speckles disseminated in the shale matrix. (a-d) Graptolite fragments characterized by biological morphologies with sharp outlines. (b, c) Graptolite with a spindle shape. $(e, f)$ Chitinozoan fragment with a scalene shape. $(g, h)$ Acritarch body and its central cavity closed with irregular ruptures.

ranges. The peaks of log differential pore volume increase with increasing TOC content. Pores of diameter approximately $0.5 \mathrm{~nm}$ provide a significant amount of pore volume.

MICP was applied to quantify the pore structure of diameter $>5 \mathrm{~nm}$, especially for macropore diameter $>50$ $\mathrm{nm}$. A certain pressure of mercury intrusion corresponds to a specific pore diameter. The volume of mercury intrusion under different pressures reflects pore volume within the corresponding pore size. The mercury intrusion curves exhibit two different trends in studied samples, which are presented in Figures 15(a) and 15(b). Samples N2 to N5 with relatively lower TOC content are examples of type I. The volume of mercury intrusion first increases $(0.01-1 \mathrm{MPa})$ and is then kept stable (1-400 MPa) (Figure 15(a)). Samples N8 to N10 are another type of curve. The volume of mercury intrusion shows a rapid increase $(0.01-1 \mathrm{MPa})$, a relatively stable phase (1-50 MPa), and a rapidly increasing phase (50-400 MPa) (Figure 15(b)). Maximum volumes of mercury intrusion, i.e., the total pore volumes, range from 0.007 to $0.020 \mathrm{~cm}^{3} / \mathrm{g}$, with an average of $0.011 \mathrm{~cm}^{3} / \mathrm{g}$. The specific surface area ranges from 1.49 to $3.83 \mathrm{~m}^{2} / \mathrm{g}$, with an average of $2.72 \mathrm{~m}^{2} / \mathrm{g}$.

Different mercury injection curves are closely correlated with TOC content and also indicate different pore size distributions. The relationship between pore size distribution and log differential pore volume is shown in Figure 16, which exhibits basically similar variations and trends in studied shales. It is obvious that the log differential pore volume featured distribution with two peaks at 3$12 \mathrm{~nm}$ and $900-2500 \mathrm{~nm}$, which suggests that pores within these two intervals account for a major contribution to total pore volume obtained by MICP. Additionally, the inconsistency of pore size distribution in different samples indicates a strong heterogeneity of pore networks.

3.5. Pore Structure and Its Relationship with TOC and Mineral Composition in Wufeng-Longmaxi Shale. Pore struc- ture parameters (i.e., pore volume and surface area) were obtained by $\mathrm{CO}_{2}$ gas adsorption and MICP. The cumulative micropore pore volume, micropore surface area, and macropore volume show an obvious increasing trend with TOC content that changed from $\sim 1 \%$ to $\sim 3 \%$, but no such change trend in the macropore surface area. For samples with TOC contents of $0.96 \%-1.31 \%$, the average micropore volume is $0.00113 \mathrm{~cm}^{3} / \mathrm{g}$, and the average micropore surface area is $3.984 \mathrm{~m}^{2} / \mathrm{g}$. For samples with TOC contents of $2.98 \%$ $3.52 \%$, the average value is $0.00237 \mathrm{~cm}^{3} / \mathrm{g}$, and the average micropore surface area is $8.123 \mathrm{~m}^{2} / \mathrm{g}$.

The quartz content has a positive influence on the micropore surface area, micropore volume, and macropore volume when the quartz content is above $\sim 40 \%$. Clay mineral content has a negative influence on the micropore surface area, micropore volume, and macropore volume when its content is above $30 \%$. However, when the TOC is below $~ 3 \%$, the increasing clay mineral content is positively correlated to micropore and macropore volumes.

3.6. Variations in Functional Group Abundances among Maceral Groups. The purpose of using micro-FTIR analysis was to investigate whether differences between macerals are also reflected in their chemical structures and, in particular, if chemical functional groups can differentiate between zooclasts and pyrobitumen. Micro-FTIR is capable of characterizing the chemical properties of in situ particles of macerals as small as $10-30 \mu \mathrm{m}$. The main difficulty with this technique is recognizing and identifying macerals under a dry objective. Therefore, only macerals of relatively large size were analyzed by FTIR, i.e., pyrobitumen in Wufeng-Longmaxi shale and graptolite in Wufeng-Longmaxi shale and Utica shale. To facilitate maceral identification, photomicrographs under reflected light microscopy were taken prior to FTIR analysis. IR signals derived from the following functional groups were of 


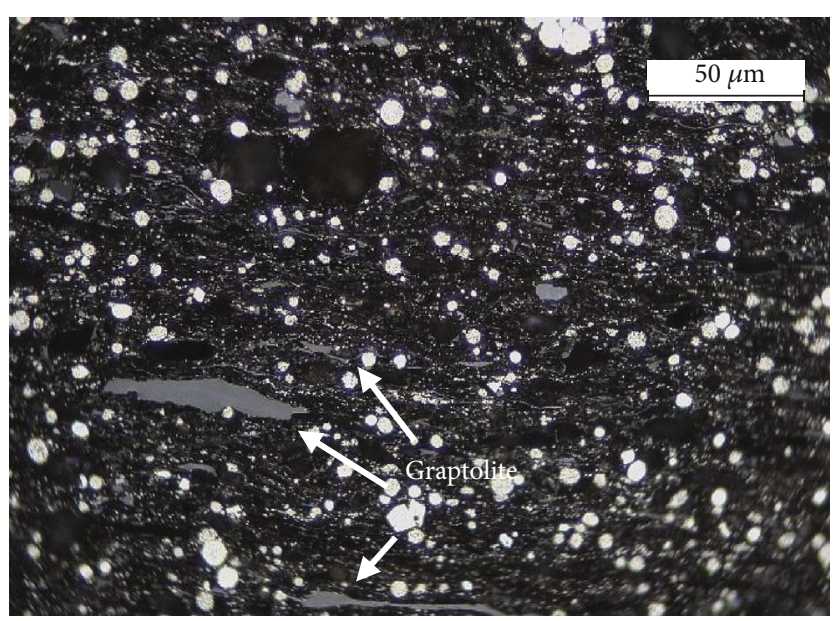

(a)

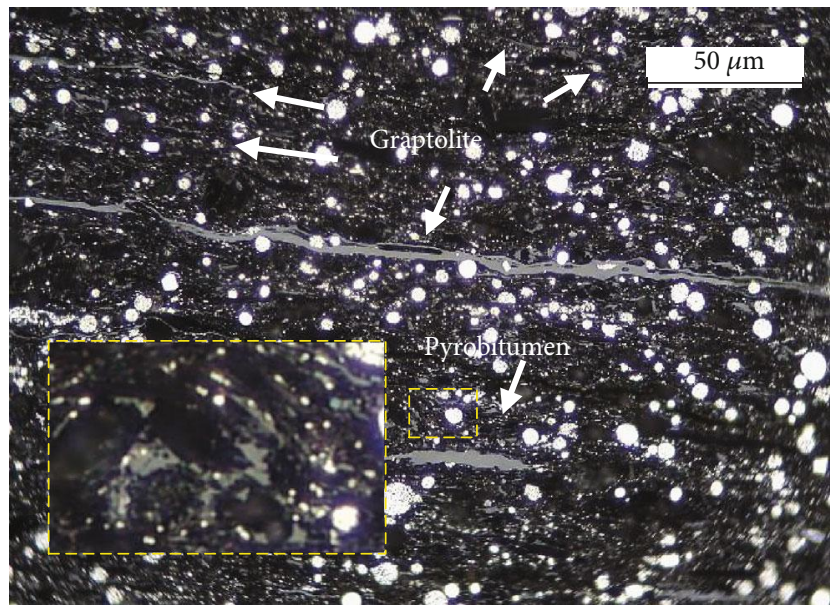

(c)

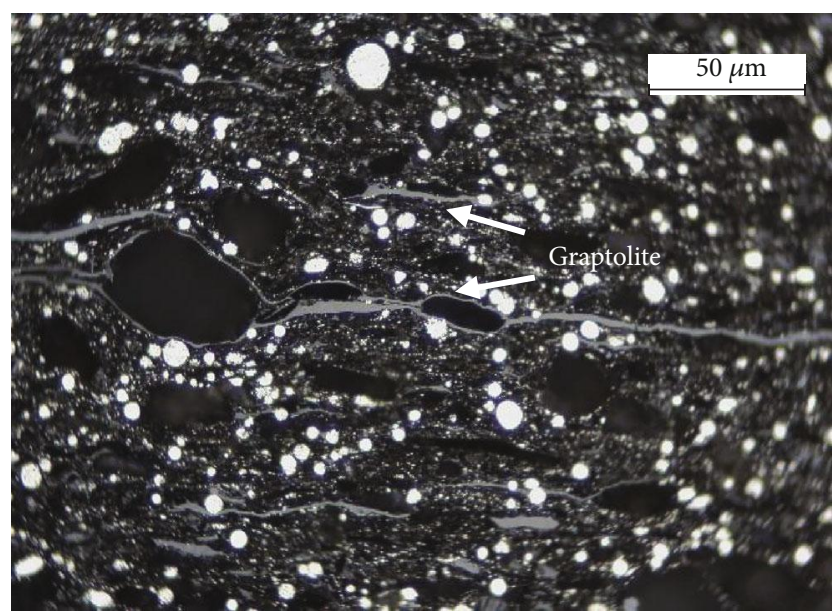

(e)

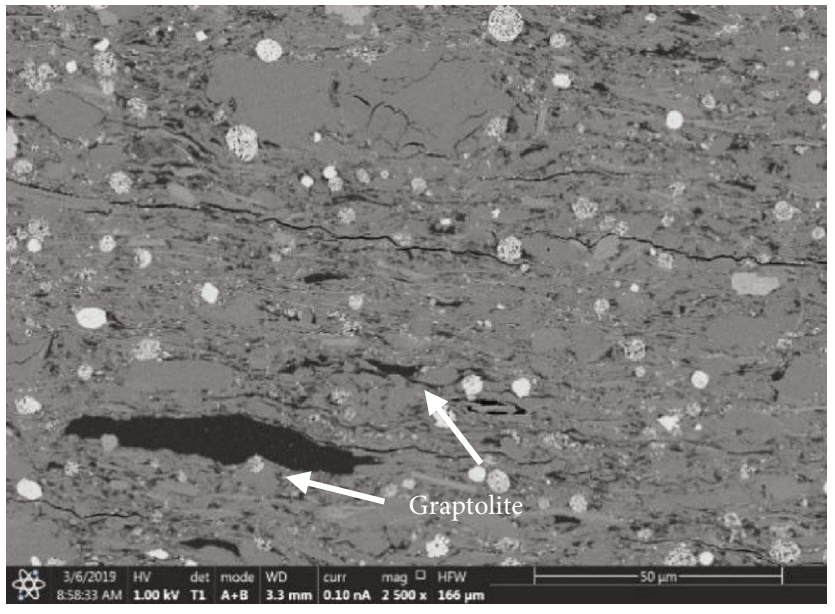

(b)

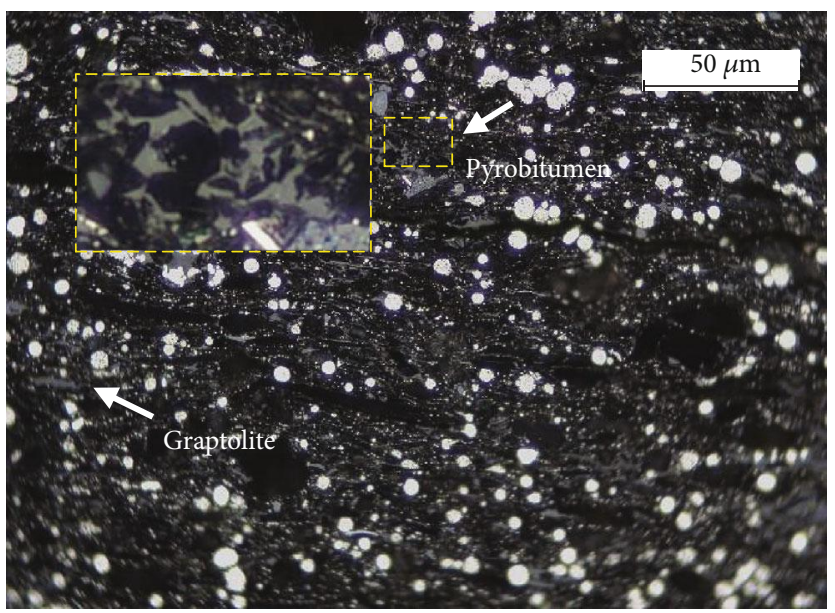

(d)

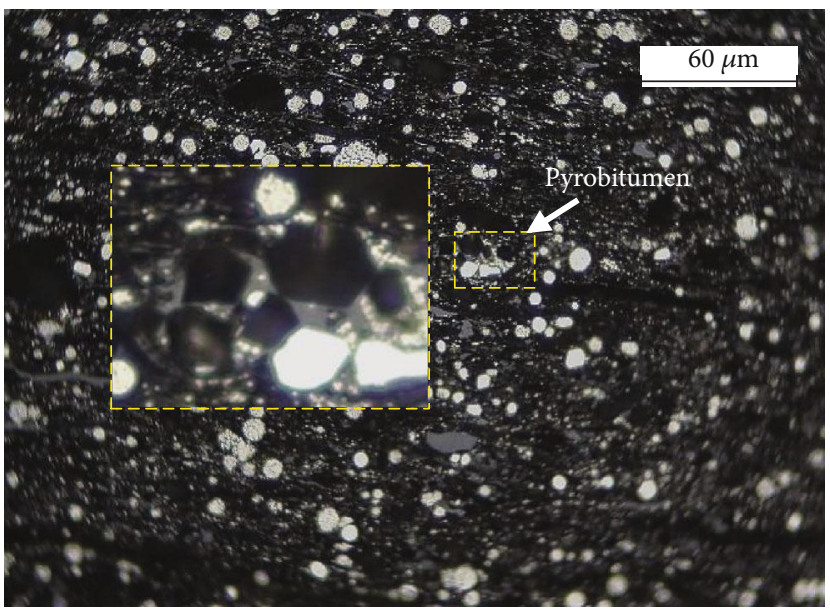

(f)

Figure 7: Organic petrography photomicrographs (oil immersion, white incident light) (a, c-f) and SEM images (b) showing typical maceral types (graptolite and pyrobitumen) and distributions of sample TRA-10. (a, b) The microscopy (a) and SEM (b) analysis on the same area of TRA-10. The larger rectangles in (c, d, f) are enlarged areas of the related smaller rectangles. $(\mathrm{a}, \mathrm{b})$ Typical graptolite grains occurred as large pieces and oriented in a direction parallel to the bedding plane. (c, $d, f$ ) Thinner graptolite pieces dispersed within the shale matrix. (c-f) Small pyrobitumen (less than a few micrometers) grains filled in minerals and oriented in various directions. (e) Some graptolites of a spindle or lenticular shape. 


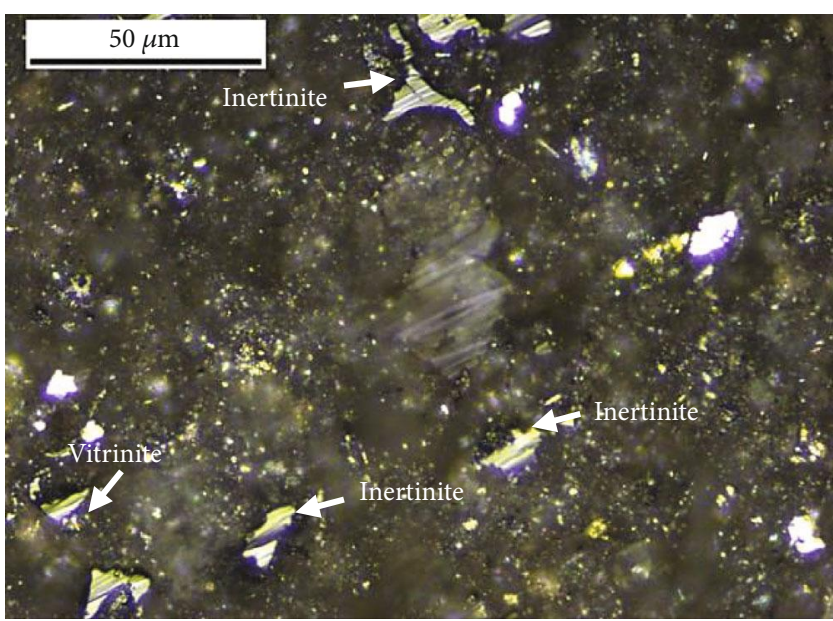

(a)

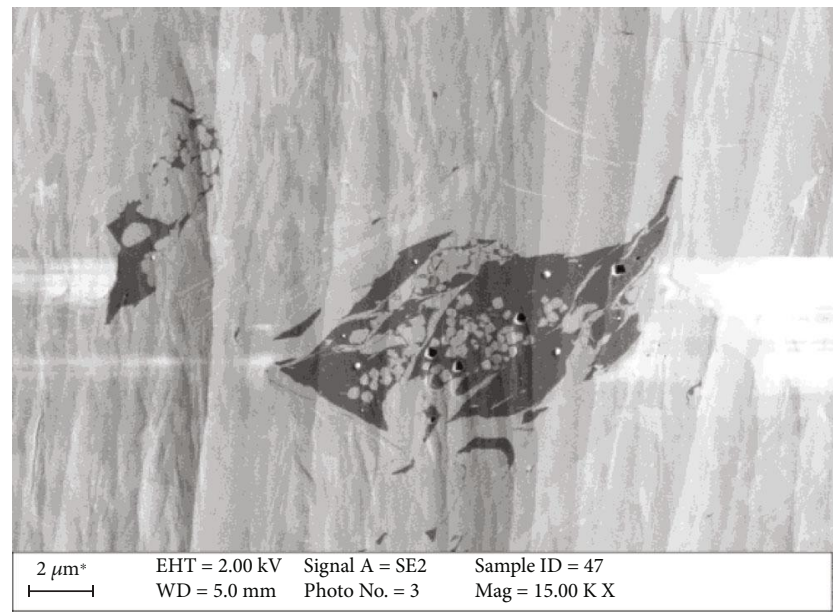

(c)

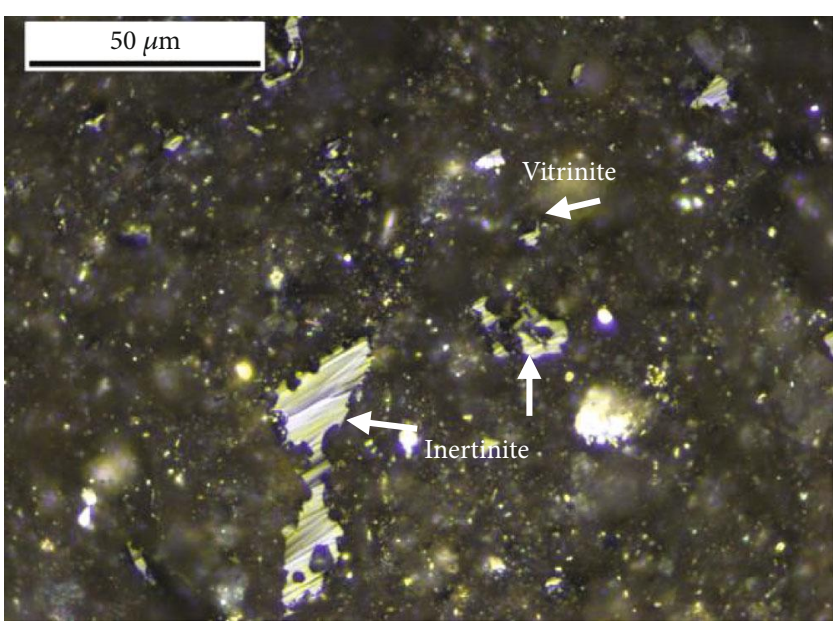

(b)

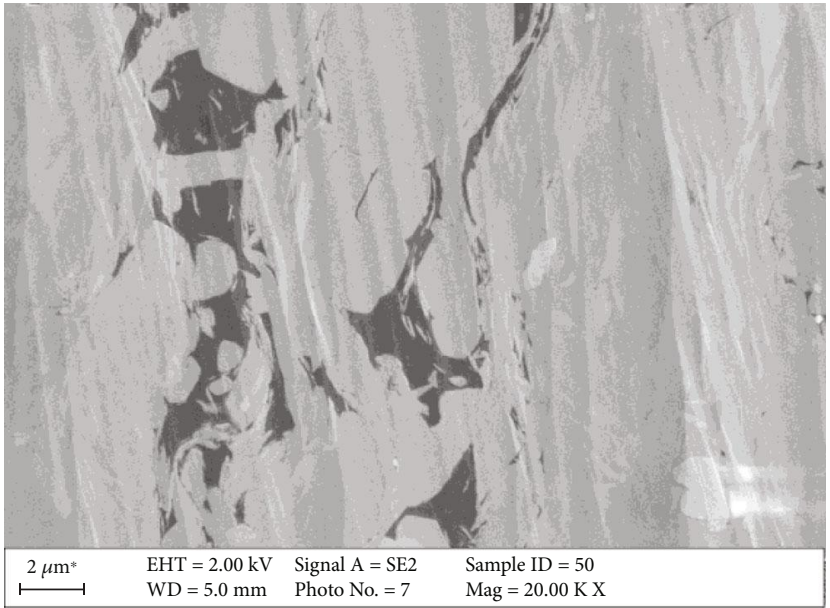

(d)

Figure 8: $(a, b)$ Organic petrography photomicrographs (oil immersion, white incident light) of Ordos shale. The maceral of Ordos shale is composed of vitrinite and inertinite. (c, d) SEM images showing typical maceral types and the internal pore structure of Xiuwu shale.

particular interest to this study: (i) aromatic $\mathrm{CH}_{x}$ stretching in the $3000-3100 \mathrm{~cm}^{-1}$ region, (ii) aliphatic $\mathrm{CH}_{x}$ stretching at $2800-3000 \mathrm{~cm}^{-1}$, (iii) oxygenated groups at $1650-1800 \mathrm{~cm}^{-1}$, and (iv) aromatic $\mathrm{C}=\mathrm{C}$ ring stretching at $1550-1650 \mathrm{~cm}^{-1}$ [99].

The micro-FTIR spectra of pyrobitumen and graptolites in the samples studied are compared in Figure 17(a). Most analyzed particles were very small and close to the detection limits of the technique. Because of small particle sizes, the spectra are noisy; however, most functional groups were easily detectable. In this study, pyrobitumens show very weak absorbance in both aliphatic $\mathrm{CH}_{x}$ stretching at 2800$3000 \mathrm{~cm}^{-1}$ and aromatic $\mathrm{CH}_{x}$ stretching between wavenumbers $3000-3100 \mathrm{~cm}^{-1}$. They exhibit weak absorbance in oxygenated groups at $1650-1800 \mathrm{~cm}^{-1}$ and aromatic $\mathrm{C}=\mathrm{C}$ ring stretching at $1550-1650 \mathrm{~cm}^{-1}$. In comparison, graptolites feature more distinct aliphatic $\mathrm{CH}_{x}$ stretching at $2800-3000 \mathrm{~cm}^{-1}$ and higher absorbance of oxygenated groups at $\sim 1710 \mathrm{~cm}^{-1}$.

Previous FTIR spectra of alginite, AOM, solid bitumen, vitrinite, and inertinite studied by Wei et al. [89] on early mature Devonian New Albany Shale (marine mature shale, kerogen type II) are shown in Figure 12(b) for comparison. We note that our study used the same experimental method as Wei et al. [89]. Compared with macerals in NAS, graptolite spectra from this study are very similar to those of vitrinite and inertinite of Wei et al. [89]; they display relatively strong peaks at $2800-3000 \mathrm{~cm}^{-1}$ and $1710 \mathrm{~cm}^{-1}$. Compared to solid bitumen from NAS, the pyrobitumen of the present study has weaker absorbance of aliphatic $\mathrm{CH}_{x}$ stretching and aromatic $\mathrm{CH}_{x}$ stretching at $2800-3000 \mathrm{~cm}^{-1}$ and $3000-3100 \mathrm{~cm}^{-}$ ${ }^{1}$ functionalities. The $\mathrm{C}=\mathrm{O}$ and aromatic $\mathrm{C}=\mathrm{C}$ peak intensities in pyrobitumen and solid bitumen appear similar.

\section{Discussion}

4.1. Compositional Controls on Porosity and Pore Structure. Previous studies have indicated that different origins of quartz could have different influences on shale porosity. Some studies proposed that the porosity increases with increasing detrital quartz content due to the compaction weakening effect and presence of intergranular pores between quartz grains $[10,100,101]$. In addition, quartz of 


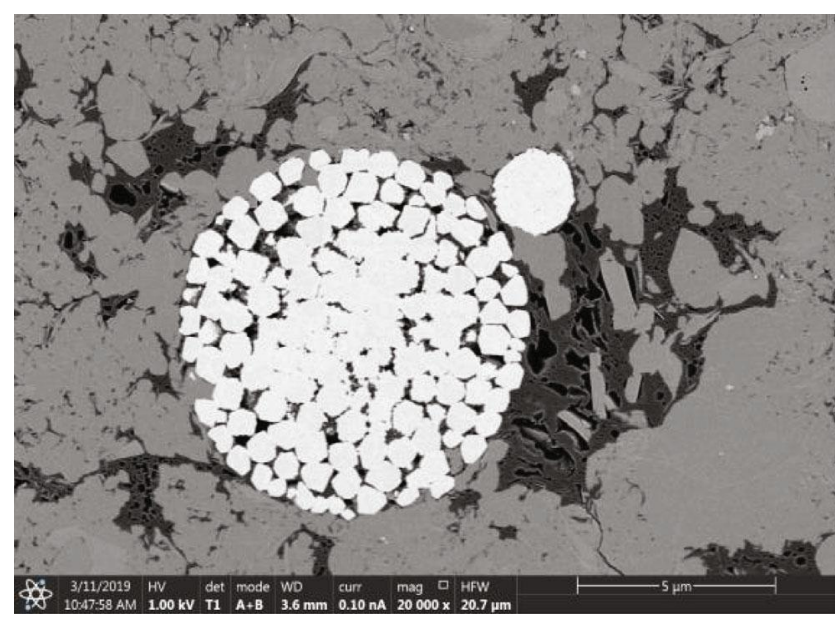

(a)

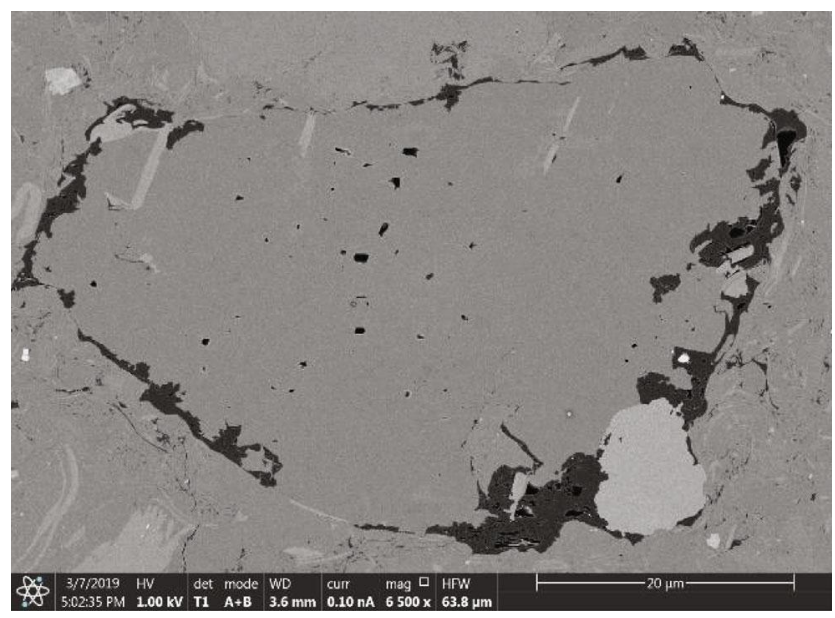

(c)

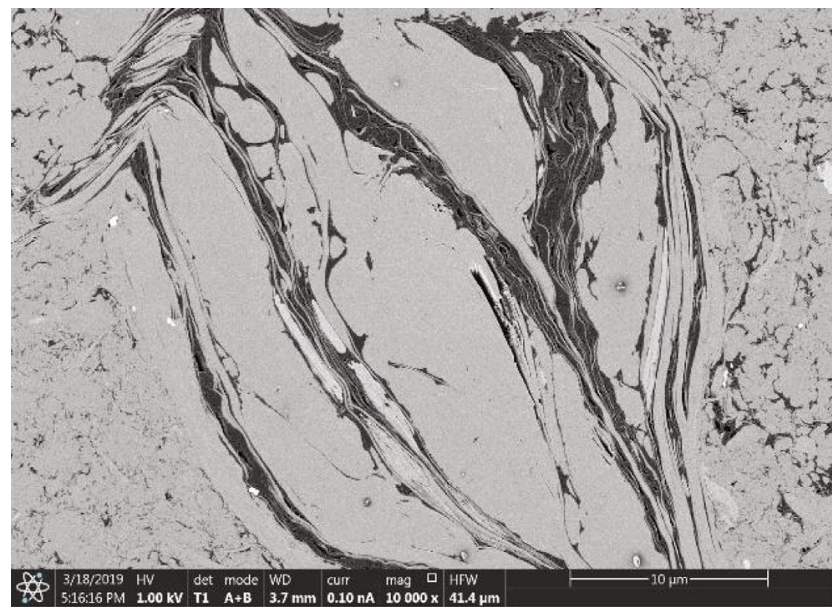

(e)

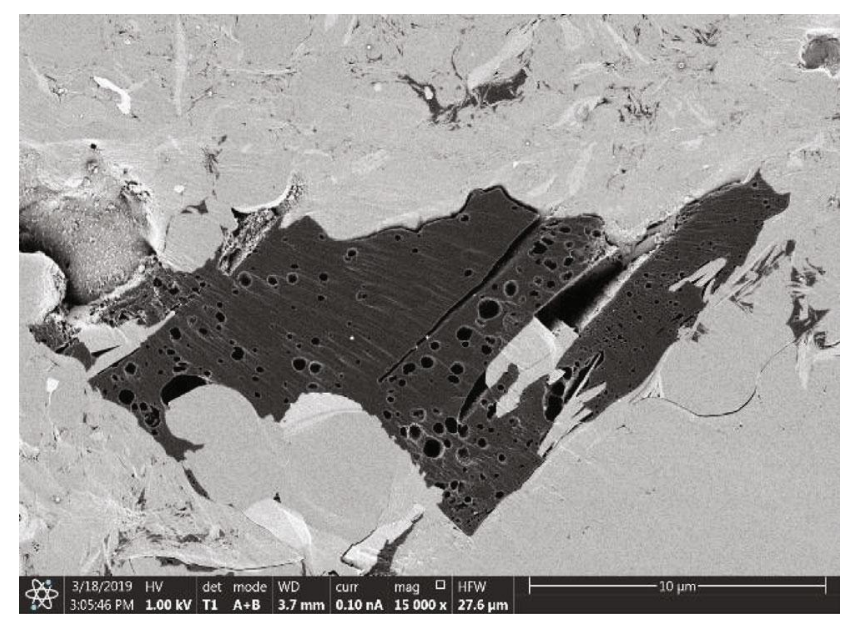

(b)

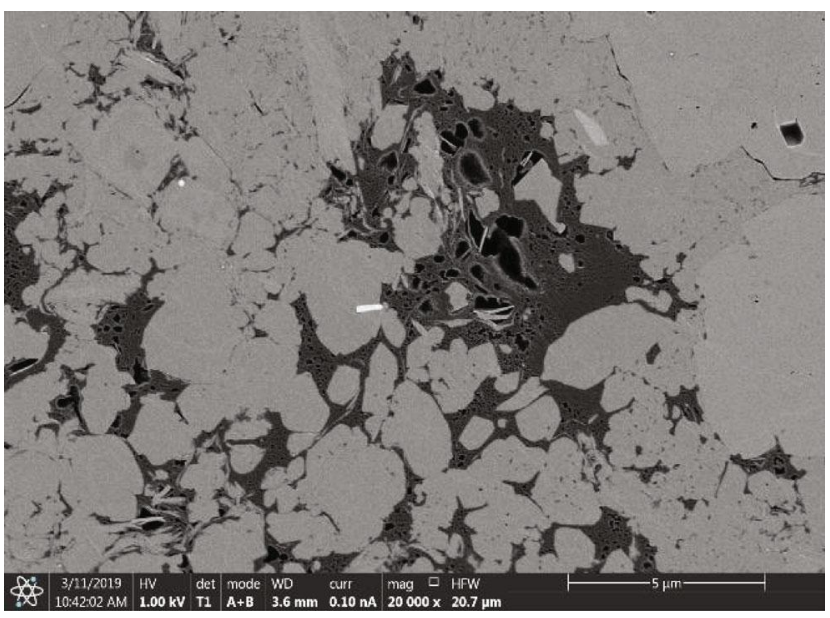

(d)

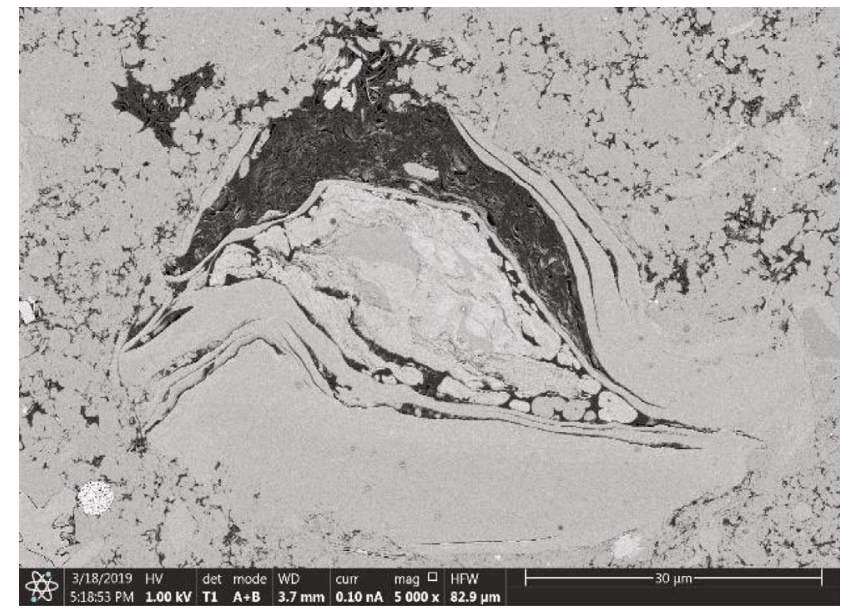

(f)

FIGURE 9: SEM images showing pyrobitumen and related pores in Wufeng-Longmaxi shale samples. (a-d) Pyrobitumen pieces with subround to round pores. Pyrobitumen is associated with minerals having a relatively regular shape and lower brightness. (b) Gas-related round pores with a tail-like structure within pyrobitumen. (e, f) Irregular or deformed pores in pyrobitumen filled with minerals of a curved to highly contorted scaly and silk thread laminar structure.

biogenic origins obviously plays a positive role in the porosity because of increasing TOC content $[13,102]$. In comparison, the increasing biogenic quartz content could also decrease porosity due to secondary cementation of biogenic silica [103]. In our study, the quartz effect is also closely correlated to its origin. For relatively clay-poor shales (clay mineral 


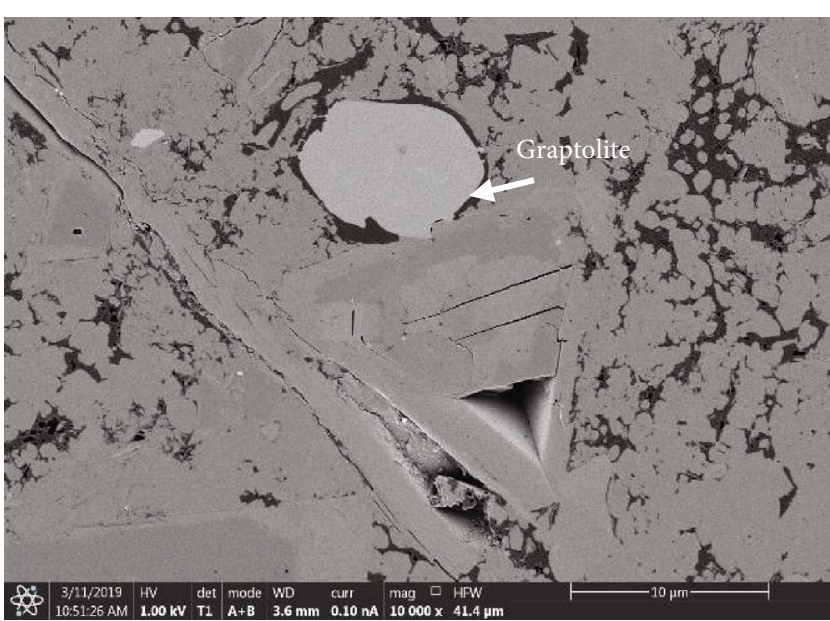

(a)

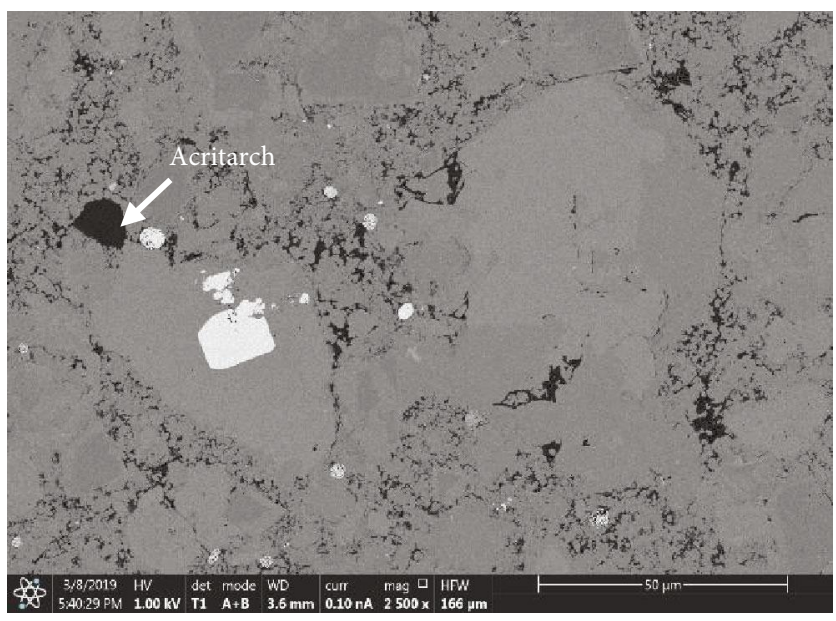

(c)

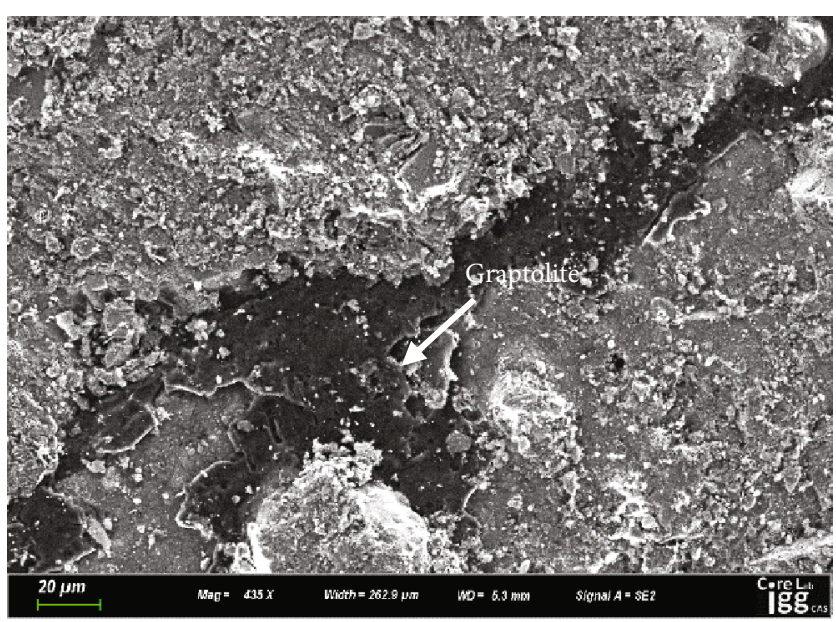

(e)

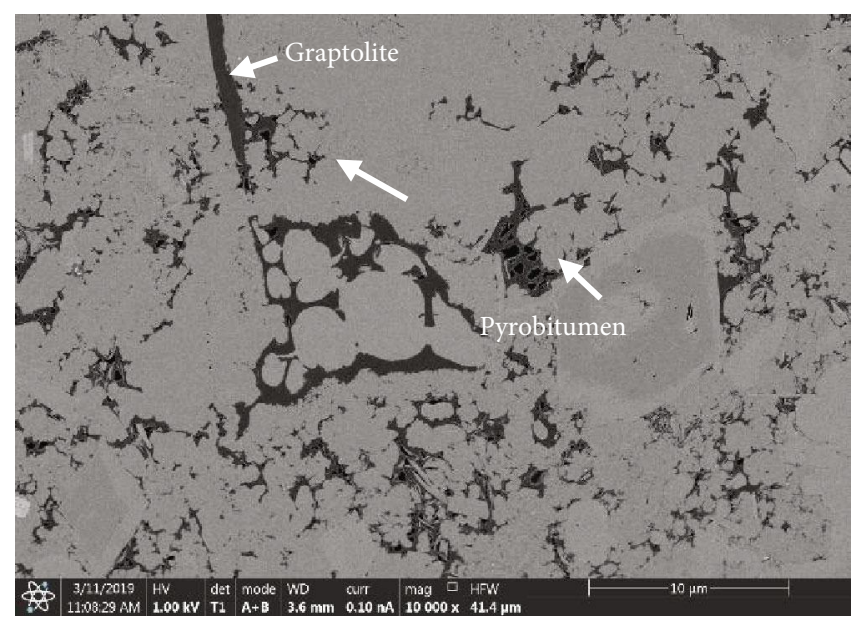

(b)

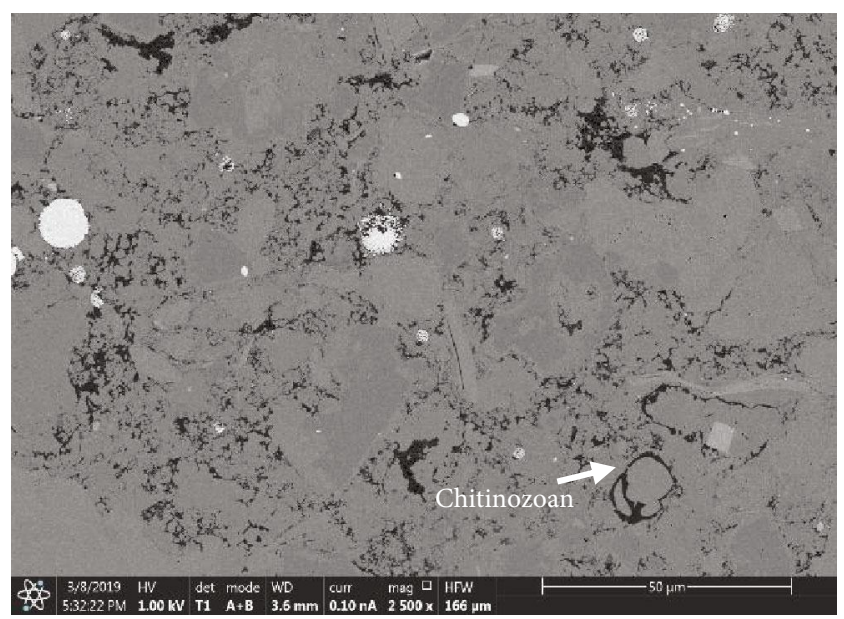

(d)

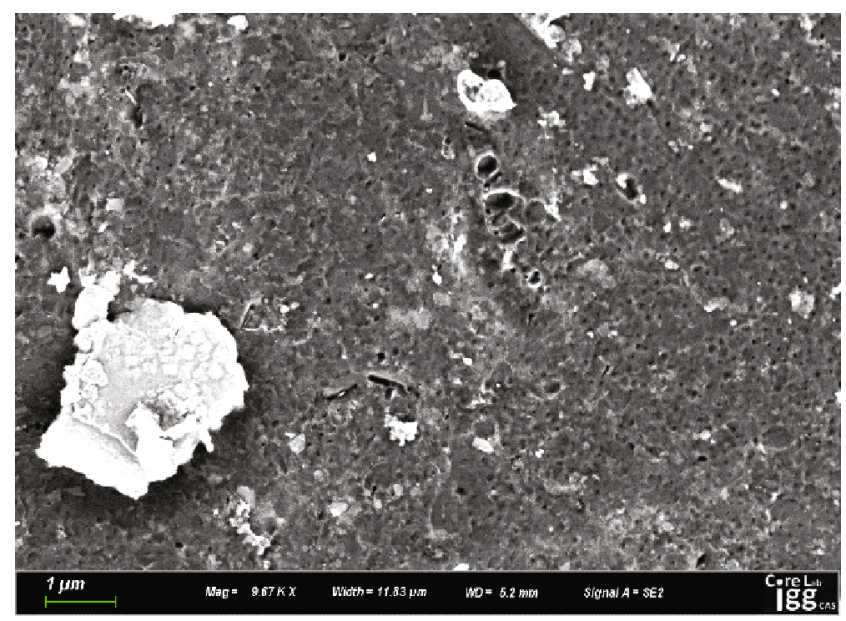

(f)

Figure 10: Continued. 


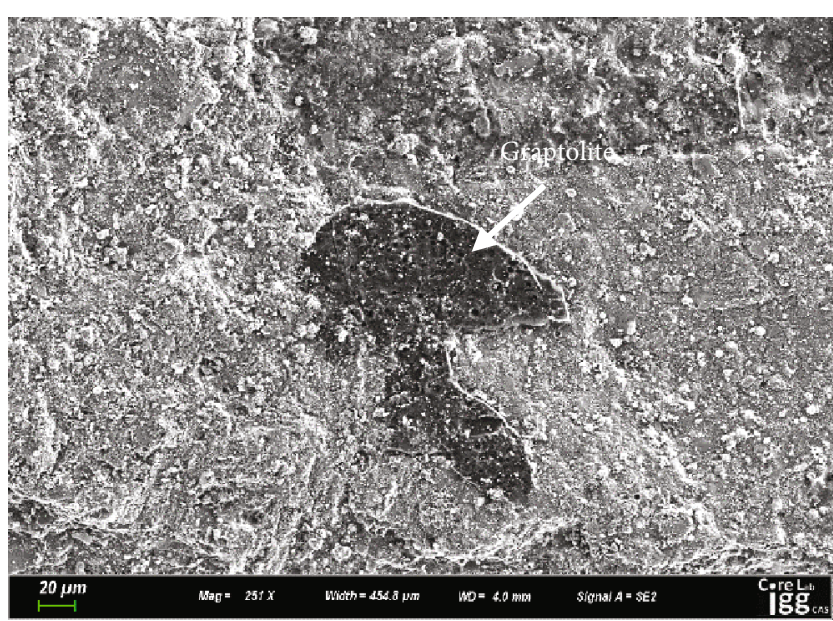

$(\mathrm{g})$

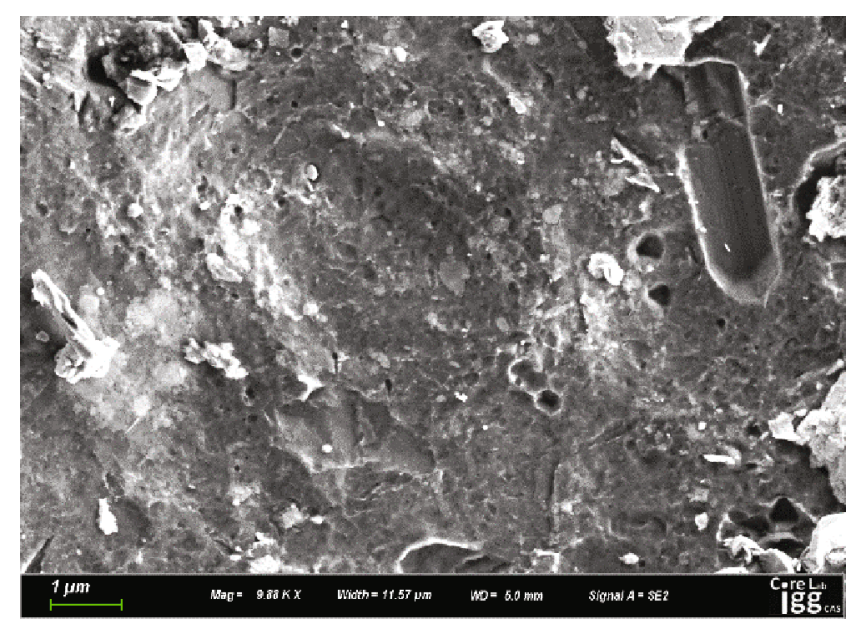

(h)

FIGURE 10: SEM images showing zooclast types and related pores in Wufeng-Longmaxi shale samples. (a-d) Zooclasts, including graptolite, chitinozoan, and acritarch, have no observable pores. (e, g) SEM images of graptolite in natural cores with no polishing. (f, h) Enlarged images of $(e, g)$ in the arrow-pointed area, respectively.

content $<35 \%$ ), quartz content is positively correlated with increasing TOC content, suggesting that the quartz in these shales is closely correlated with the biogenic origin, which is also indicated in previous studies $[13,102,104]$. For relatively clay-rich shales, quartz could mainly come from detrital input and has a weak correlation with the TOC content. Accordingly, different relationships between quartz and TOC content are attributed to the differences in their depositional environment and source input of quartz $[65,105]$. In our study, there is also a positive correlation between TOC content and shale porosity parameters (pore volume and pore surface area). However, this relationship has a TOC content boundary. The existence of this boundary could result from different maceral types in OM, which would be discussed in Sections 4.2 and 4.3. When the TOC content in studied samples $>2 \%$, the positive correlation is stronger than that in shale with $\mathrm{TOC}<2 \%$. The OM shows strong control than other factors in shales. In addition, the clay mineral content in shales is around $35 \%$ with the $2 \%$ boundary of TOC content. For clay-rich shales, OM and clay minerals together control pores in shales. The above different controls are due to the development of organic pores and also source input of quartz from detrital or biogenic origins. Content of biogenic quartz strongly correlates to $\mathrm{OM}$ and positively increases porosity compared to that of detrital quartz.

The OM plays a positive role in the micropore structure of Wufeng-Longmaxi shales. When the TOC content is above $1.5 \%$, an obvious increase and strong positive relationship were found between TOC content, micropore volumes, and micropore surface areas, highlighting the large abundance of smaller pores within the organic fraction. However, the relationship between TOC content, macropore volumes, and macropore surface areas is not obvious. Clay mineral has a positive influence on macropores. The clay-rich shales usually have low TOC content, which reflects a significant contribution of clays to pore structure in organic-lean shales. Furthermore, pores in clays are usually well developed around quartz grains since rigid quartz grains can form pres- sure shadows that prevent pores in clays from collapsing (Yang et al. 2016).

4.2. Organic Matter Types and Transformation with Maturation. The Ordovician to Early Silurian time interval represents a period of black shale deposition under stratified and anoxic bottom-water conditions in basins of China, North Africa, the Middle East, North America, and Europe $[12,53,106,107]$. Those organic-rich shales are the source of large amounts of hydrocarbons and therefore were the subject of intensive studies on sedimentology and source rock evaluation ([5, 7, 53, 106, 107]; Yang et al. 2016). Reported major OM in these early Paleozoic sediments include AOM, algal Tasmanites, solid bitumen, chitinozoans, and graptolites [62-64] ranging from the early mature to postmature stage. Our study analyzed maceral composition in marine Wufeng-Longmaxi shale and Utica shale deposits of Late Ordovician-Early Silurian age from China and the U.S. Those shales feature a high maturity level at the postmature stage. The majority of the original kerogen is thermally degraded, and petrographic observations show that the pyrobitumen and zooclasts (graptolites and chitinozoans) are the dominant OM components. Pyrobitumen is dominant in Wufeng-Longmaxi shale, whereas graptolites dominated $\mathrm{OM}$ in Utica shale samples.

Because most prolific gas-producing shales are postmature [108-110] and organic porosity provides important storage capacity for gas $[3,5,6,26]$, understanding the characterization of OM and organic pores in postmature shales is very important in evaluating shale reservoir properties.

Previous studies indicate that each maceral evolves differently with maturation $[27,111]$. With increasing maturity, from immature to postmature, oil-prone kerogen (AOM and alginite) first transforms to preoil bitumen and then to oil, gas, and postoil bitumen or pyrobitumen (e.g., [45]). Liu et al. [45] concluded that AOM and alginite began transforming to solid bitumen at the mature stage and that the solid bitumen network followed the original AOM network. 


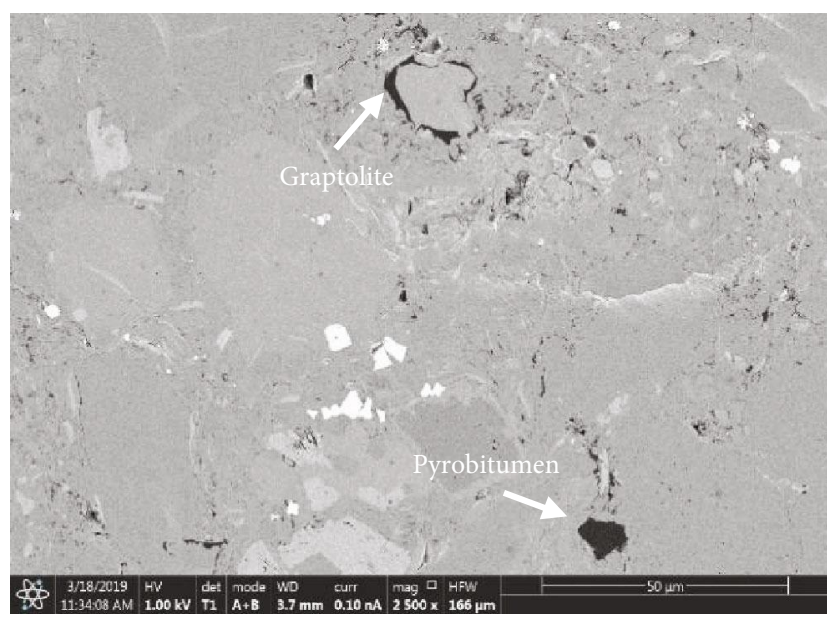

(a)

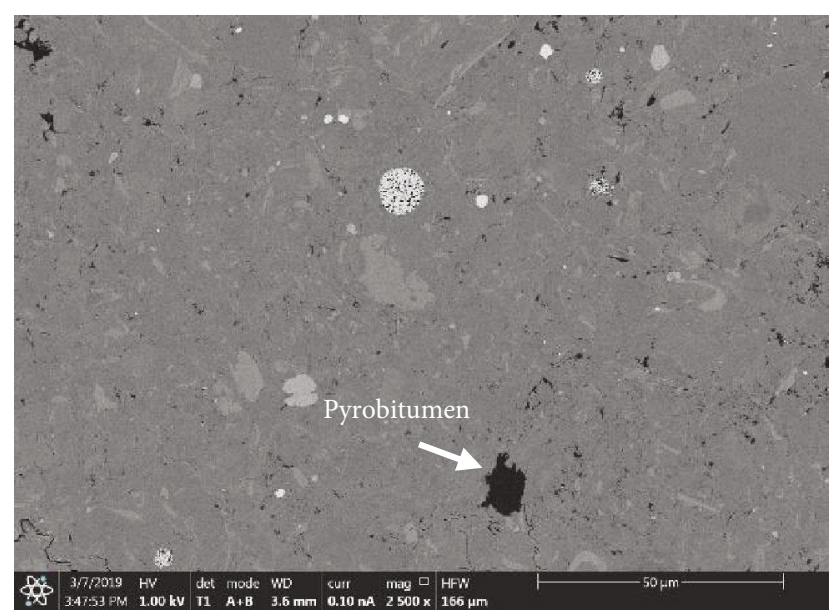

(c)

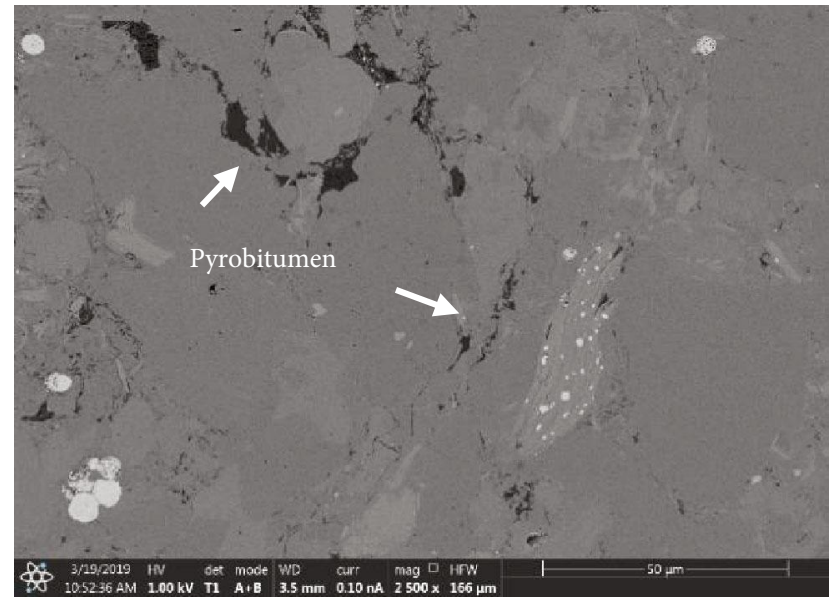

(e)

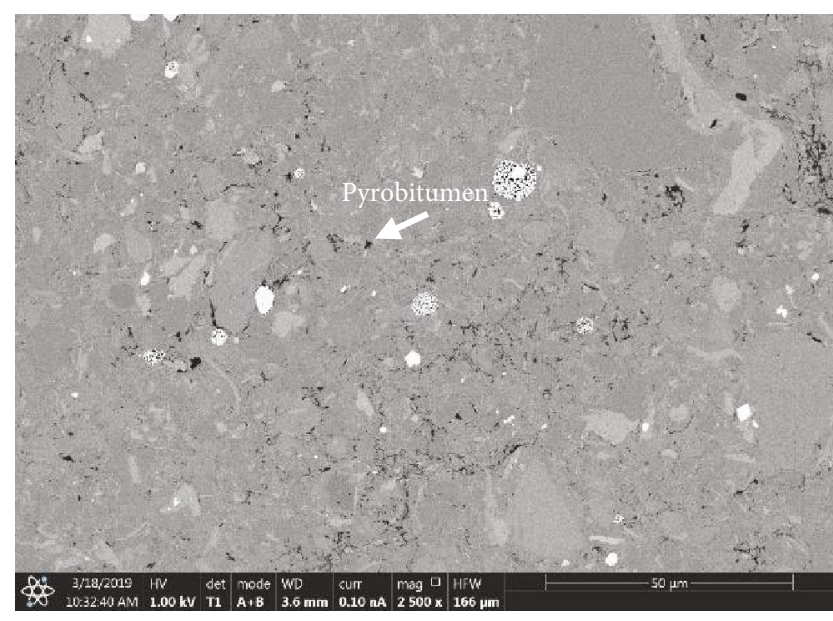

(b)

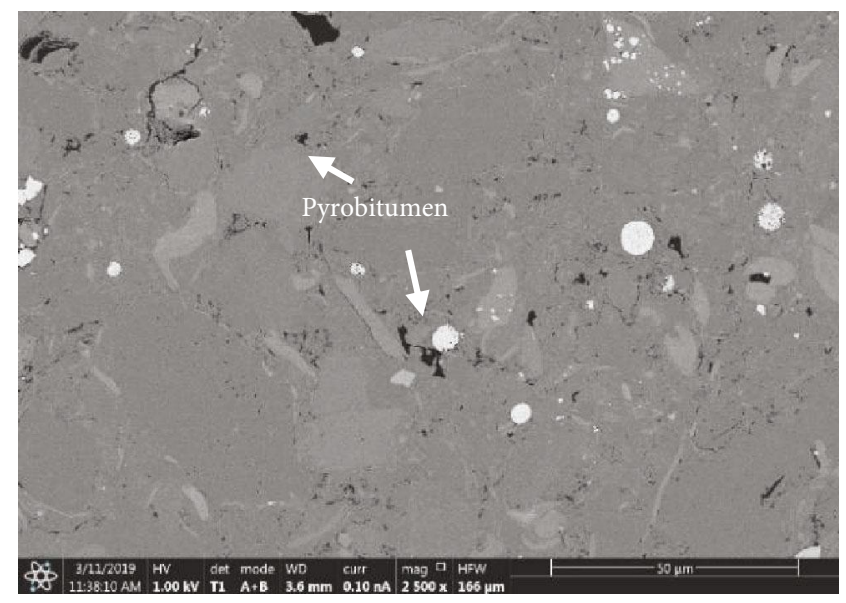

(d)

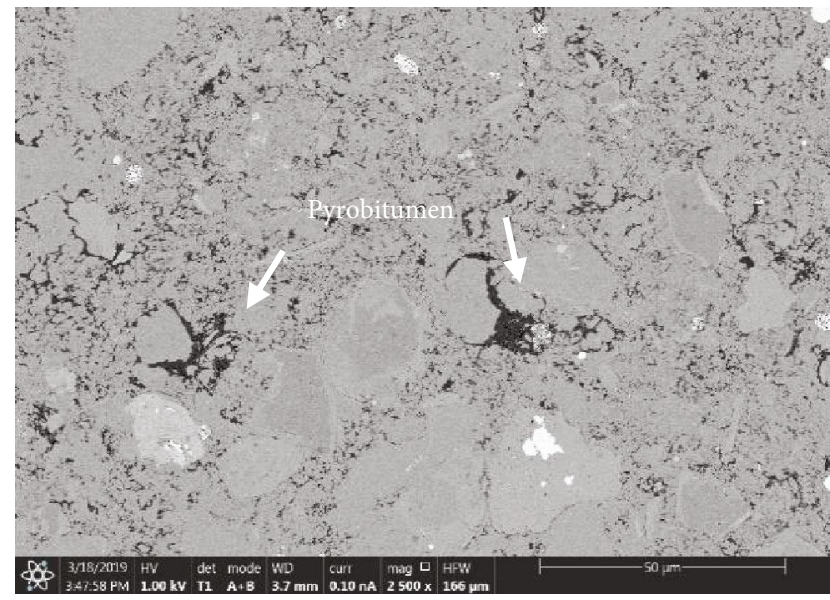

(f)

Figure 11: Continued. 


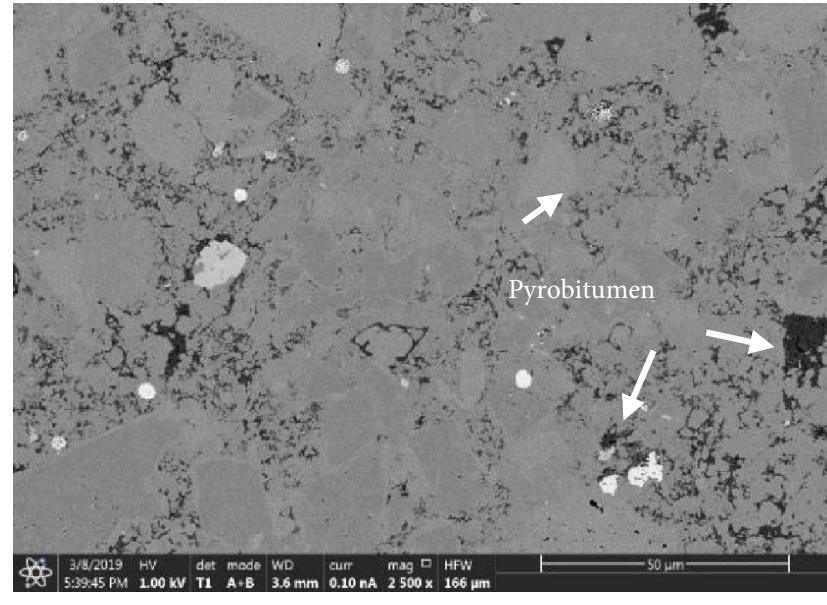

(g)

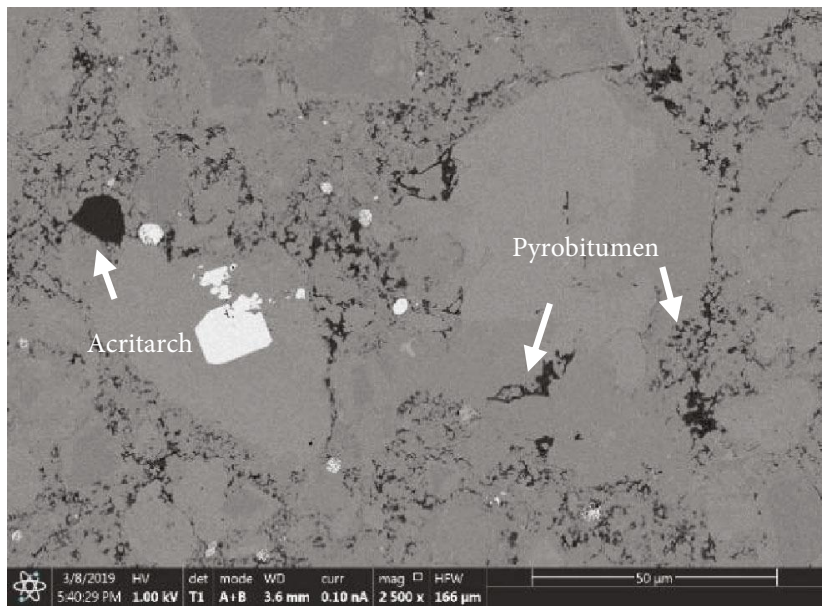

(h)

FIGURE 11: SEM images showing maceral types and related pores observed in Wufeng-Longmaxi shales. (a-h) Selected samples under SEM at depths of $2481 \mathrm{~m}, 2503 \mathrm{~m}, 2513 \mathrm{~m}, 2534 \mathrm{~m}, 2567 \mathrm{~m}, 2573 \mathrm{~m}, 2576 \mathrm{~m}$, and $2577 \mathrm{~m}$, respectively. The organic matter content increases with deeper depth $(\mathrm{a}-\mathrm{h})$ in the studied samples and can be reflected by the area of dark material $(\mathrm{a}-\mathrm{h})$. Pyrobitumen is the dominant maceral in samples, and its content shows an obvious increase in samples from $2567 \mathrm{~m}$ deep and deeper.

Cardott et al. [27] also suggested that a postoil solid bitumen network could have developed along the AOM network. Mastalerz et al. [111] proposed that the $1.5 \%$ solid bitumen reflectance (equivalent $\mathrm{VR}_{\mathrm{o}}$ of approximately $1.33 \%$, based on the empirical formula by Jacob [93]) could be considered the boundary between solid bitumen and pyrobitumen. In both Wufeng-Longmaxi shale and Utica shale, most pyrobitumen occurrences are very small (a few micrometers), scattered within the matrix, and porous. Compared to the solid bitumen reported from shales ranging from the early mature to postmature stage $[45,89,98,111,112]$, pyrobitumen in our studied samples is smaller and more porous. We conclude that solid bitumen becomes more porous and scattered throughout the matrix during transformation to pyrobitumen as a result of secondary cracking. Researchers also suggest that with an increase in maturity to above 3.0\%, OM could transform from amorphous carbon to crystalline graphite $[70,74]$. When pyrobitumen loses its potential for generating hydrocarbons, no additional organic pores could be generated [74, 113, 114]. Wood et al. [115] proposed that the morphology of pyrobitumen resulted from its different origins in shales. Specifically, the curved margin of porefilling pyrobitumen is a reflection of the original oil-water interface. The laminar structure within pyrobitumen was formed from increments of the viscous flow of oil into the original pore structure. The globular/granular texture was formed by the early precipitation of asphalt floccules from an unstable precursor oil phase in the central portions of large open pores. In our studied samples at the overmature stage $\left(\mathrm{VR}_{\mathrm{o}}=\sim 2.4 \%\right)$, the previously mentioned morphologies are not clearly reflected. Most pyrobitumens have a clear pore-filling structure and condensed morphology. We concluded particles except for zooclast as pyrobitumen and divided them into three types in this study. The first type is a migrated secondary product occupying interparticle space (between quartz, dolomite, K-feldspar, clay, and mica grains) and cavities. The second type occurs as isolated and condensed individual pieces occupying interparticle space $(\sim 50 \mu \mathrm{m})$, which might have been converted from oil-prone kerogen particles (AOM or alginite) in situ [45]. The third type of pyrobitumen particles having coarse surfaces might be an indicator of bacteria and fluid activity, which is also indicated in Wang et al. [85]. Different from the other pyrobitumen types, bacteria pellet-like pyrobitumen is isolated and might have a relatively weak correlation with hydrocarbon generation.

In comparison to alginite and $\mathrm{AOM}$, vitrinite and inertinite (kerogen types III and IV) derived from terrestrial woody materials do not have a high hydrocarbon generation potential, so they do not show a significant change in morphology with increasing thermal maturity. Vitrinite and inertinite are present as distinct particles across the entire maturity range, as observed in Ordos shale and another study [45].

When the maturity reaches above $3 \%$, the organic-rich shale loses its potential for hydrocarbon generation. In addition, as gas loss leads to pressure drop, the pores generated during the mature stage collapse and even disappear because they lack support $[70,74,113]$. A small amount of OM pores was preserved because of skeleton particle support [74], which is also indicated in Xiuwu shale in this study.

4.3. Maceral Pores and Their Relationship to Gas Storage. Organic matter-hosted pores are widely recognized as a significant component of the pore system in gas shales, including Wufeng-Longmaxi shale [55, 116, 117]. The strong correlation between TOC content and total porosity in studied Wufeng-Longmaxi samples supports the contribution of organic pores (Table 2). Among their macerals, pyrobitumen is the main component that hosts the organic pores detected by SEM. Pyrobitumen pores range from nanometer to micrometer in size. Some pyrobitumens with well- 


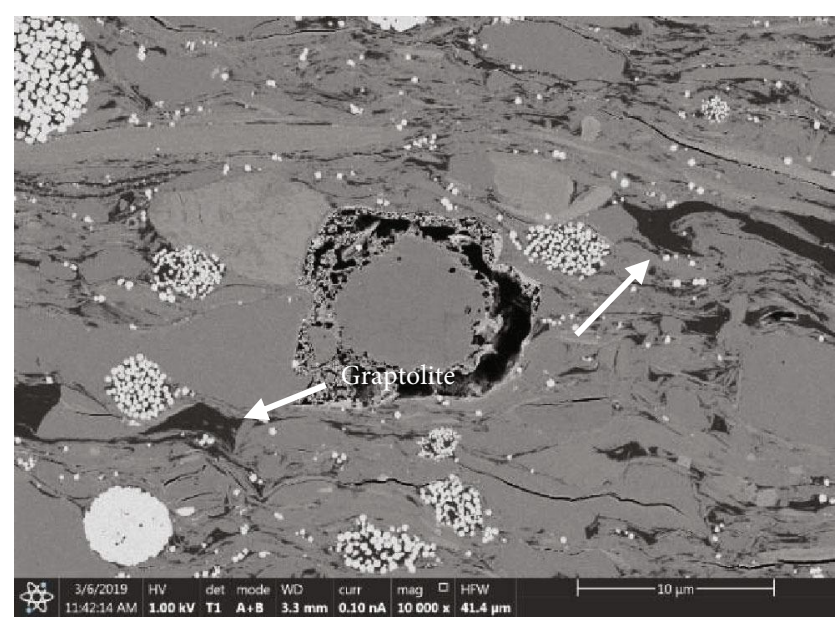

(a)

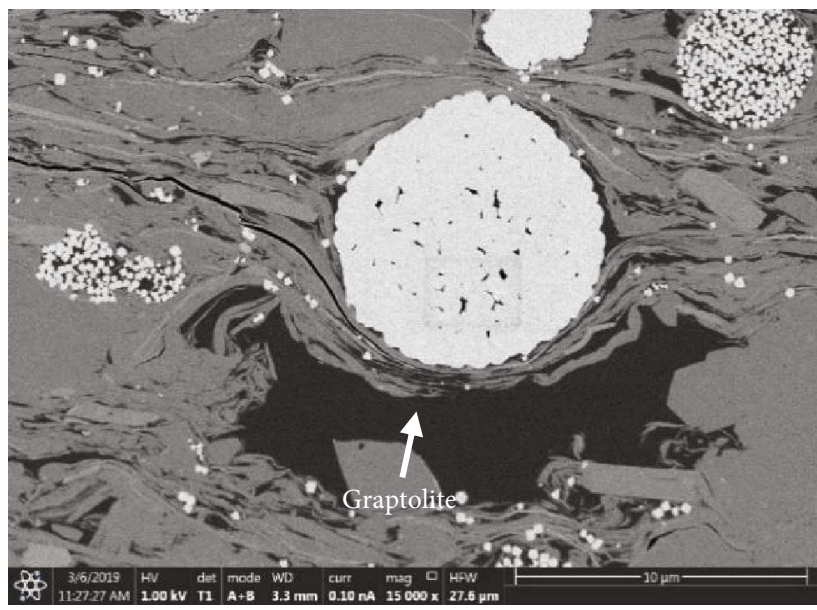

(c)

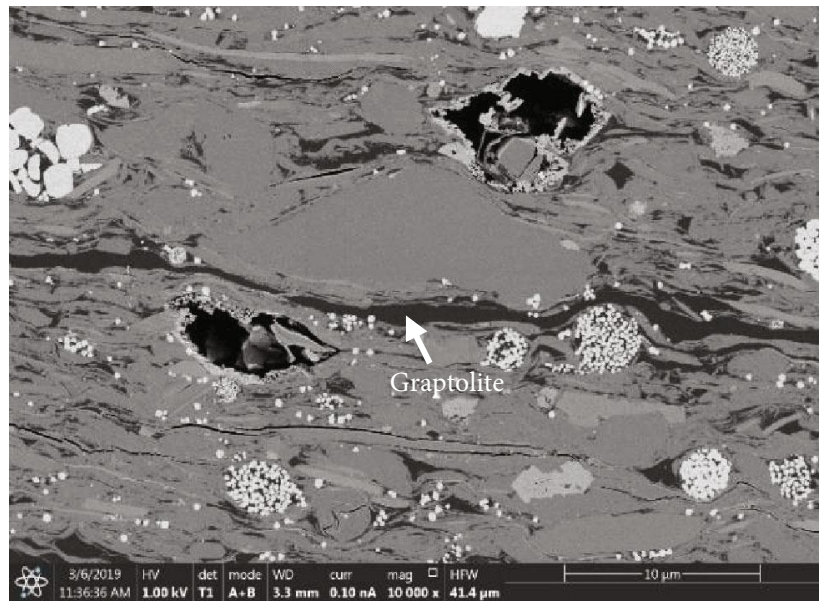

(e)

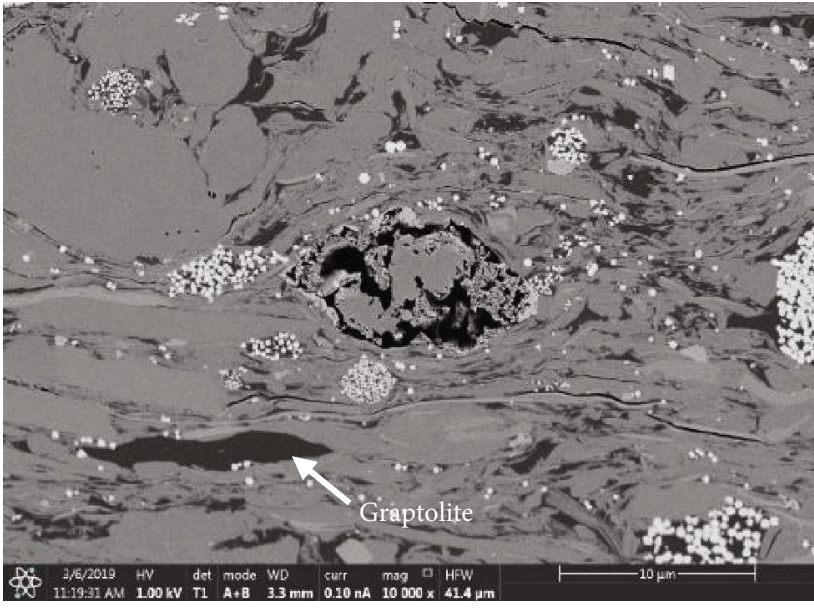

(b)

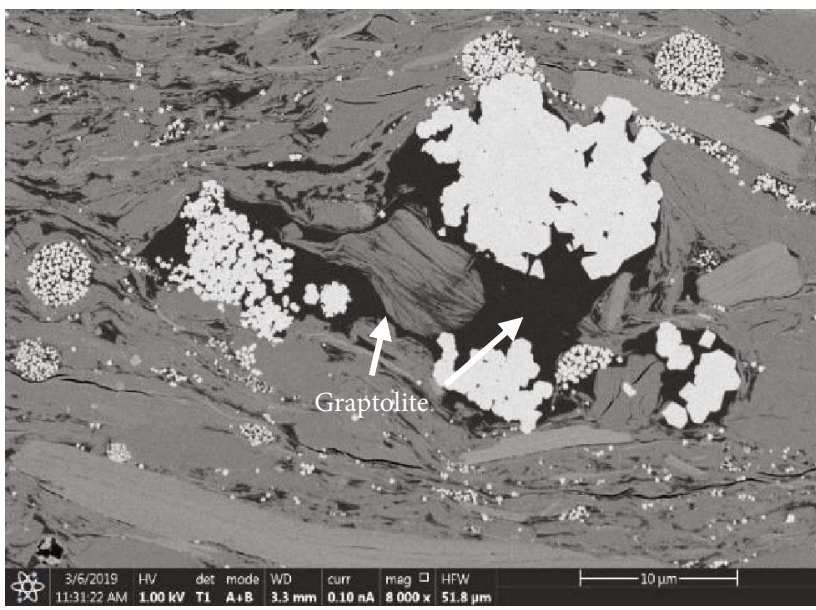

(d)

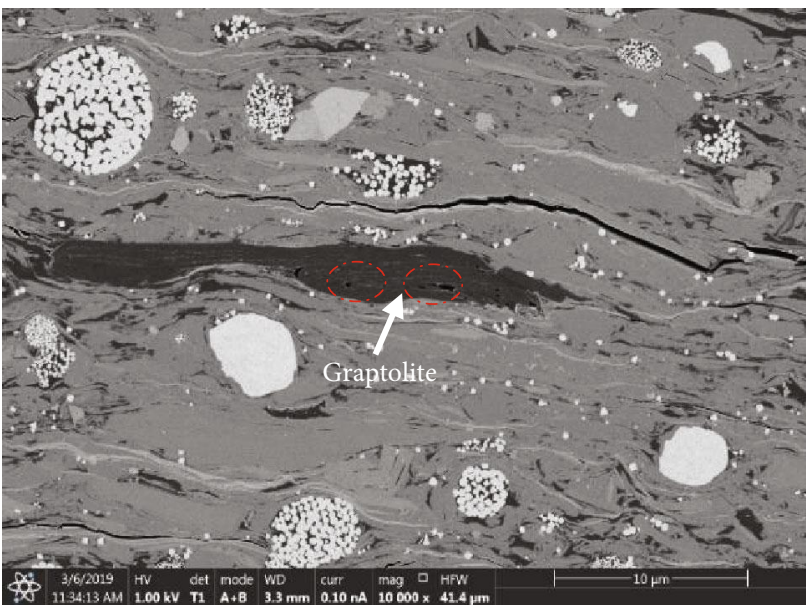

(f)

FIGURE 12: SEM images showing the typical habit and internal pore structure of organic matter in sample TRA-10. (a-f) Abundant graptolites and pyrite framboids distributed within the shale matrix. (a-c, e) Dispersed graptolite pieces without pores even enlarging current magnification. (f) A few pores of irregular and narrow shape inside graptolite grains, and the existence of such pores is not common in the studied sample.

developed nanopores were almost unidentifiable at the resolution of an optical microscope because only very thin walls remained. Subround to round pores in pyrobitumen were considered to be formed by the devolatilization of gaseous hydrocarbons from matrix-retained bitumen or oils during thermal cracking $[2,5,48,54]$. In our study, micrometer- 


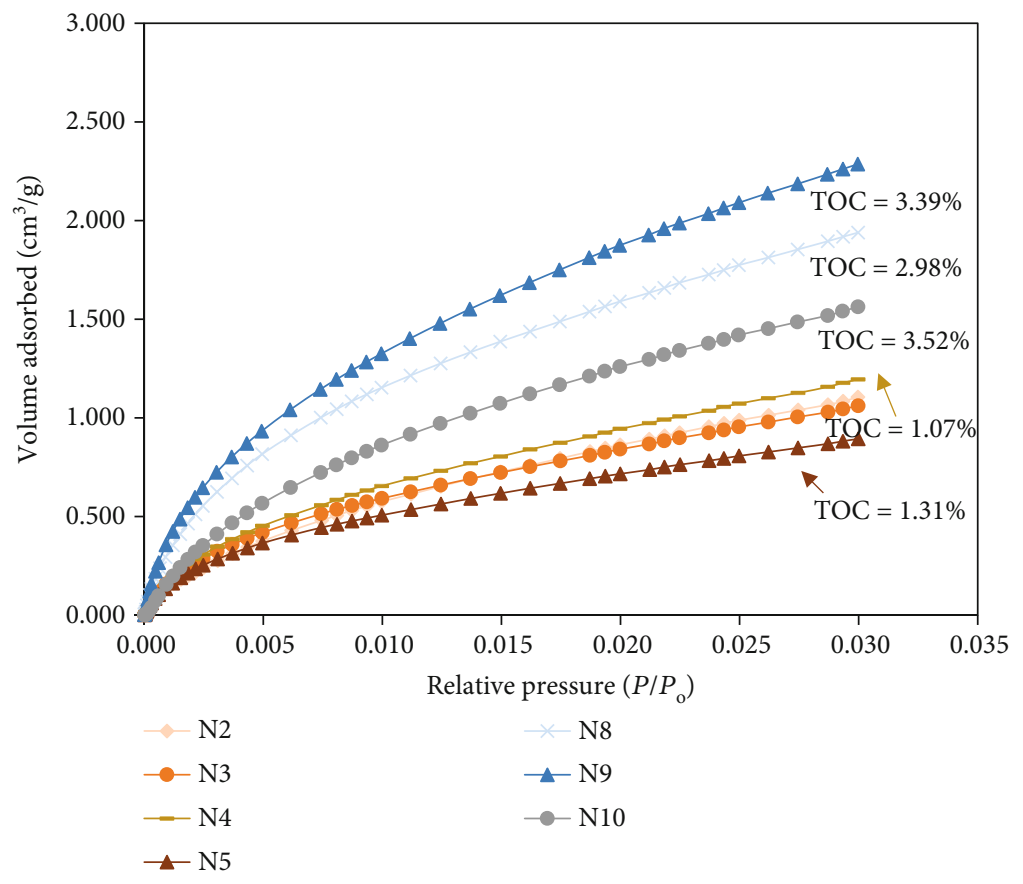

FIgURE 13: Low-pressure $\mathrm{CO}_{2}$ adsorption isotherms of Wufeng-Longmaxi shales. Note that the largest volumes of adsorbed $\mathrm{CO}_{2}$ occur in samples (samples N8, N9, and N10) of the highest TOC values. The TOC content is marked near the isotherm lines. $P=$ actual gas pressure; $P_{\mathrm{o}}=$ vapor pressure of the adsorbing gas.

TABLE 2: Micropore and macropore volumes and surface areas obtained by $\mathrm{CO}_{2}$ gas adsorption and mercury intrusion capillary pressure (MICP) in Wufeng-Longmaxi shale. The total organic carbon content is also listed in the second column from the left side.

\begin{tabular}{|c|c|c|c|c|c|}
\hline \multirow{2}{*}{ Sample ID } & \multirow{2}{*}{ Total organic carbon (TOC) content (wt. \%) } & \multicolumn{2}{|c|}{ Pore volume $\left(\mathrm{cm}^{3} / \mathrm{g}\right)$} & \multicolumn{2}{|c|}{ Specific surface area $\left(\mathrm{m}^{2} / \mathrm{g}\right)$} \\
\hline & & Micropore & Macropore & Micropore & Macropore \\
\hline $\mathrm{N} 2$ & 0.96 & 0.00110 & 0.0057 & 3.773 & 0.023 \\
\hline N3 & 0.89 & 0.00114 & 0.0053 & 4.084 & 0.025 \\
\hline $\mathrm{N} 4$ & 1.07 & 0.00127 & 0.0050 & 4.476 & 0.021 \\
\hline N5 & 1.31 & 0.00101 & 0.0053 & 3.604 & 0.014 \\
\hline N8 & 2.98 & 0.00238 & 0.0145 & 8.379 & 0.020 \\
\hline N9 & 3.39 & 0.00285 & 0.0056 & 9.887 & 0.027 \\
\hline N10 & 3.52 & 0.00187 & 0.0071 & 6.102 & 0.010 \\
\hline
\end{tabular}

sized pore shapes depend on the degree of compaction. For example, pyrobitumen with round to subround pores frequently developed between quartz or carbonate grains, which suggests that brittle minerals can protect the micrometersized organic pores from compaction at the postmature stage. In turn, irregular pores in pyrobitumen are usually associated with deformed or layered clay minerals, which are ductile and easily compacted. To some extent, micrometer-sized pores resist compaction with the help of surrounding brittle minerals. In fact, some studies indicate that pore sizes $<100$ $\mathrm{nm}$ are especially resistant to compaction [29, 118].

Zooclasts including graptolites and chitinozoan have zero to very limited pores in the studied samples, indicating that zooclasts did not undergo secondary transformation with maturation. Thus, for Utica shale and WufengLongmaxi shale at the dry gas stage, the SEM-detected porosity contribution from graptolites and chitinozoan to the total porosity in shale is negligible. Ardakani et al. [43] also reported that chitinozoans had no pores visible in their wall structure in Utica shale samples from southern Quebec at the mature to postmature stage $\left(\mathrm{VR}_{\mathrm{o}}\right.$ ranging from $\sim 1$ to $2.1 \%$ ). This could explain why the Utica shale sample with abundant zooclasts has lower porosity compared to the Wufeng-Longmaxi samples from a depth of $\sim 2576 \mathrm{~m}$ that have low contributions of zooclasts and abundant pyrobitumen. In Wufeng-Longmaxi shale, owing to the relatively low abundance and limited pore network of zooclasts, the pyrobitumen network that hosts secondary organic nanopores plays a significant role in hydrocarbon storage and migration.

With increased depths in Wufeng-Longmaxi shale, the positive relationship between pyrobitumen, porosity, and gas content emphasizes the significance of pyrobitumen in this formation. Both pyrobitumen and zooclasts contribute 

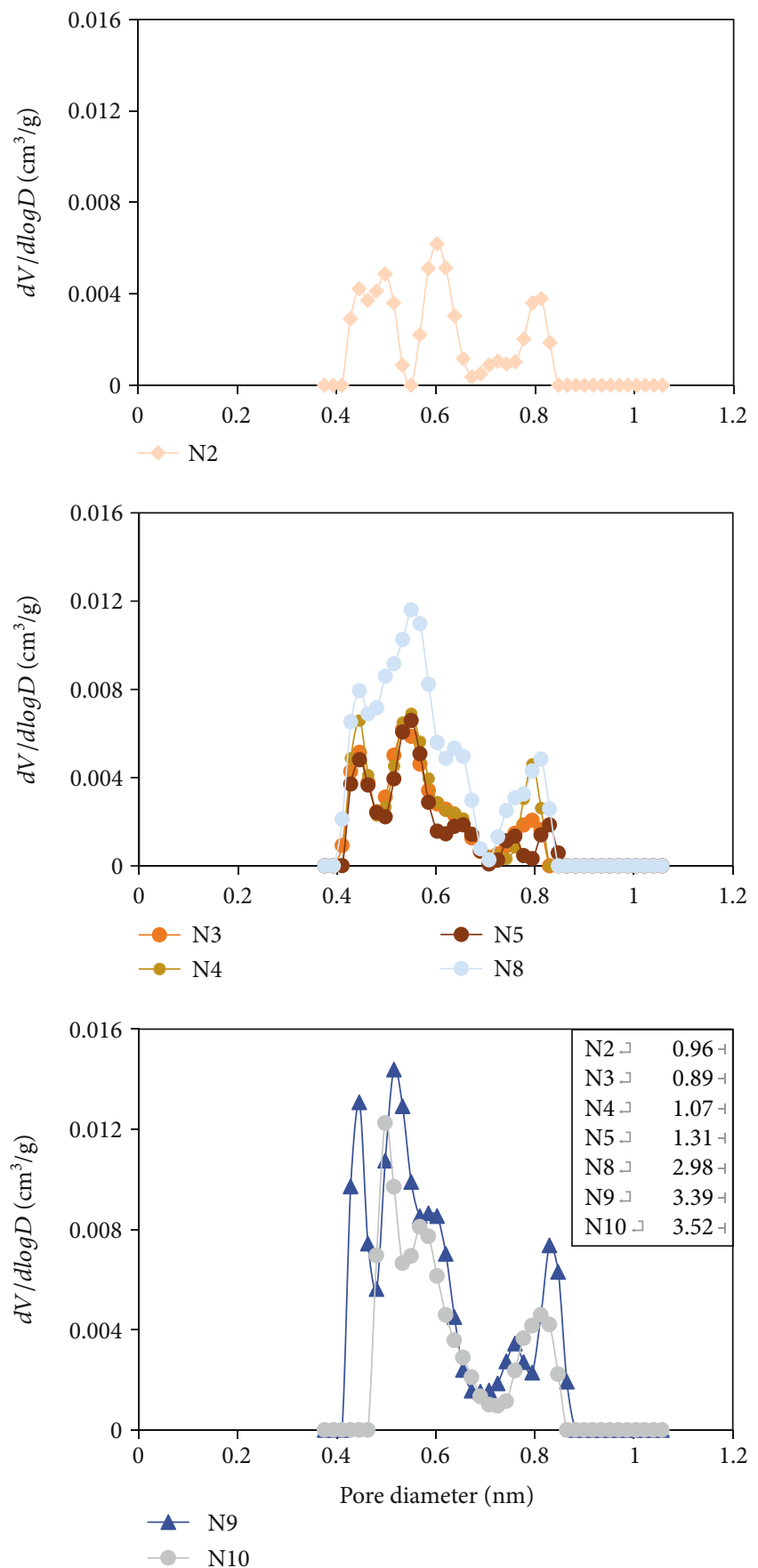

FIGURE 14: Log differential pore volume derived from low-pressure $\mathrm{CO}_{2}$ adsorption for Wufeng-Longmaxi shales with samples of different total organic carbon (TOC) contents. The TOC content (wt. \%) of each sample is marked in the rectangle in the third panel. The micropore size distribution up to $1.2 \mathrm{~nm}$ was calculated with the DFT model. Pores with diameter $<1 \mathrm{~nm}$ have different log differential pore volumes. There are three higher $d V / d \log D$ peaks at approximately $0.40-0.50 \mathrm{~nm}, 0.55-0.60 \mathrm{~nm}$, and $0.80-0.81 \mathrm{~nm}$.

to the TOC content, but not as much as porosity. The TOC content strongly controls pore development, especially for marine shales. Therefore, among high-maturity samples with comparable amounts of TOC, those having higher proportions of pyrobitumen and lower proportions of zooclasts will likely have a greater potential for gas storage. Because pyrobitumen is the secondary product from lipid material, we can conclude that a higher input of algae can provide not only greater hydrocarbon-generating ability but also more space for hydrocarbon storage.

In contrast to our observations, some researchers found that submicron- to micron-sized pores were present in graptolite structures $[55,56]$. For example, Luo et al. [55] found abundant organic pores in the nongranular graptolites in Wufeng-Longmaxi shale having equivalent $\mathrm{VR}_{\mathrm{o}}$ values ranging from 3.08 to $4.29 \%$. They also claimed 


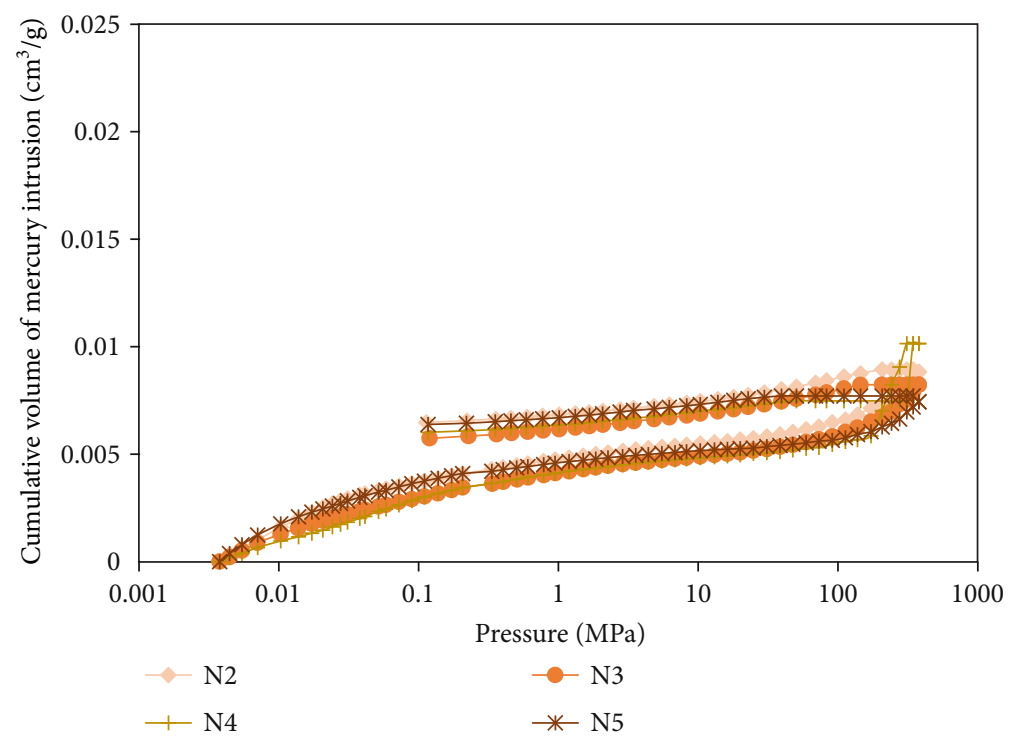

(a)

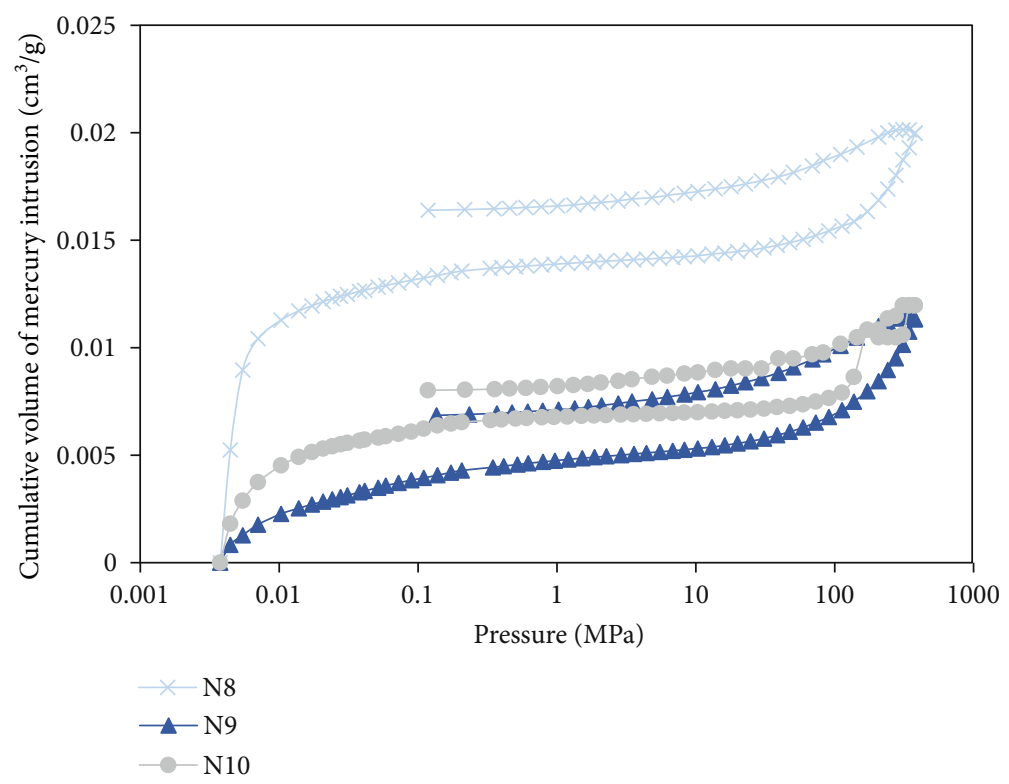

(b)

Figure 15: Mercury injection curves for Wufeng-Longmaxi shales. The mercury intrusion curves exhibit two different trends in studied samples, which are presented in $(\mathrm{a}, \mathrm{b})$. (a) Types of samples N2 to N5 with relatively lower TOC contents. The volume of mercury intrusion first increases (0.01-1 MPa) and is then kept stable (1-400 MPa). (b) Types of samples N8 to N10 with higher TOC contents. The volume of mercury intrusion shows a rapid increase $(0.01-1 \mathrm{MPa})$, a relatively stable phase $(1-50 \mathrm{MPa})$, and a rapidly increasing phase (50-400 MPa).

that graptolites account for 20 to $93 \%$ of the dispersed OM in the Wufeng-Longmaxi Formation [55]. However, the graptolites in our ion-milled Wufeng-longmaxi samples only accounted for a small portion of the whole OM (less than $20 \%$ ) and have zero to very limited pores inside. This indicates that maturity above $3.0 \%$ may change the structure of graptolites. In addition, the SEM images on unpolished WufengLongmaxi samples also show clear pores in large graptolite bodies in cores (Figures 10(e)-10(h)). One possible explanation of this discrepancy could be that the structure of graptolite is layered and soft and could be easily eroded with long- term exposure, developing a pore-like structure on the surface of unpolished cores. Ion milling removed the pore-like structure in the graptolite surface and allowed observing real internal structure in shales.

4.4. Chemical Structure of Pyrobitumen and Zooclasts. Graptolites and chitinozoans are microfossils that have thin organic walls and are common in Lower Paleozoic marine rocks $[53,62,64,119,120]$. Previous studies of pyrolysisgas chromatography on chitinozoan in mature shales suggest that their composition is similar to woody material (i.e., 

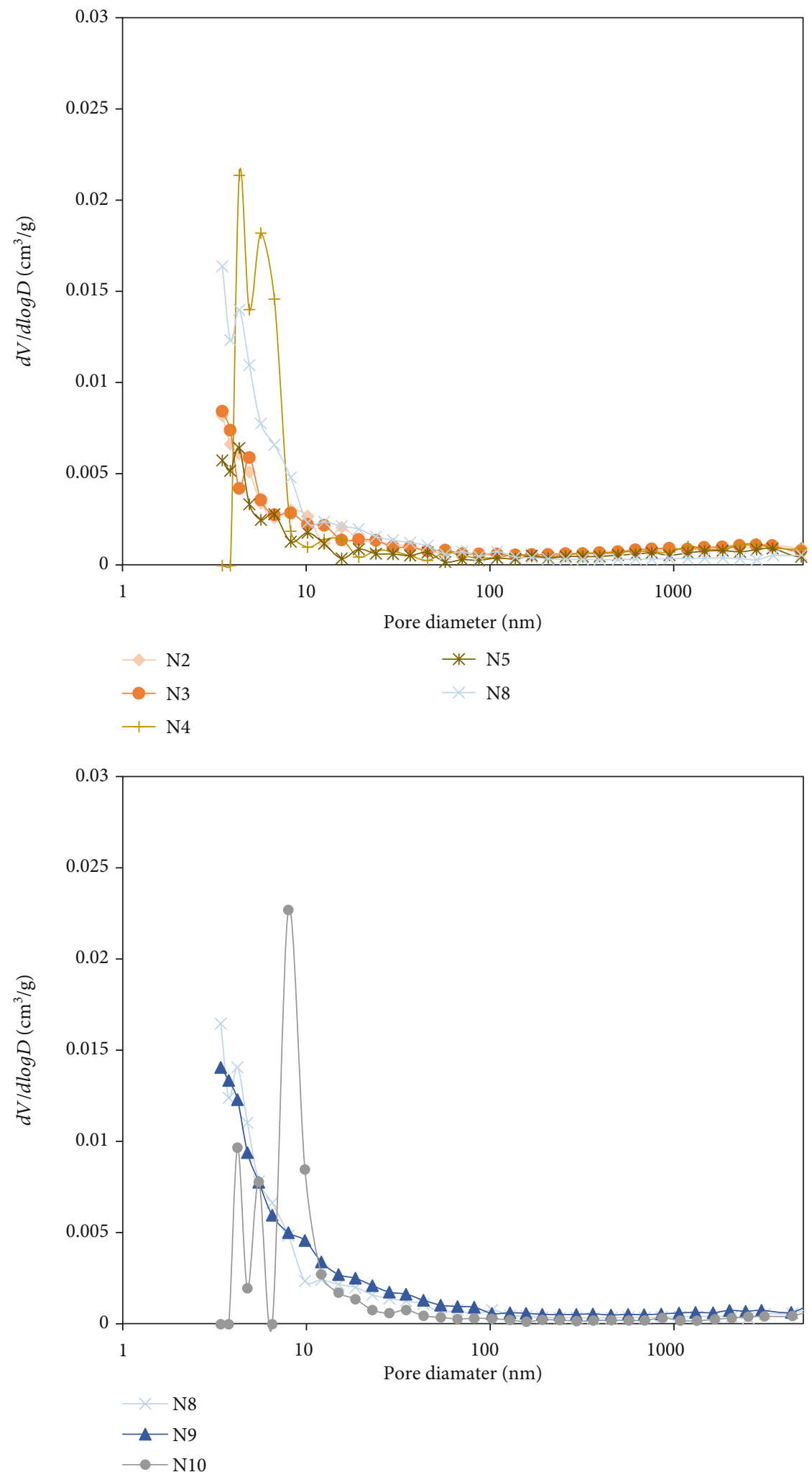

FIGURE 16: Log differential pore volume for Wufeng-Longmaxi shales derived from MICP. The $x$-axis marked the pore diameter in the nanometer, and the $y$-axis marked the log differential pore volume. Samples N8, N9, and N10 featured higher TOC contents than samples $\mathrm{N} 2$ to N8. The TOC contents of N8 to N10 are $2.98 \%, 3.39 \%$, and $3.52 \%$, respectively. 


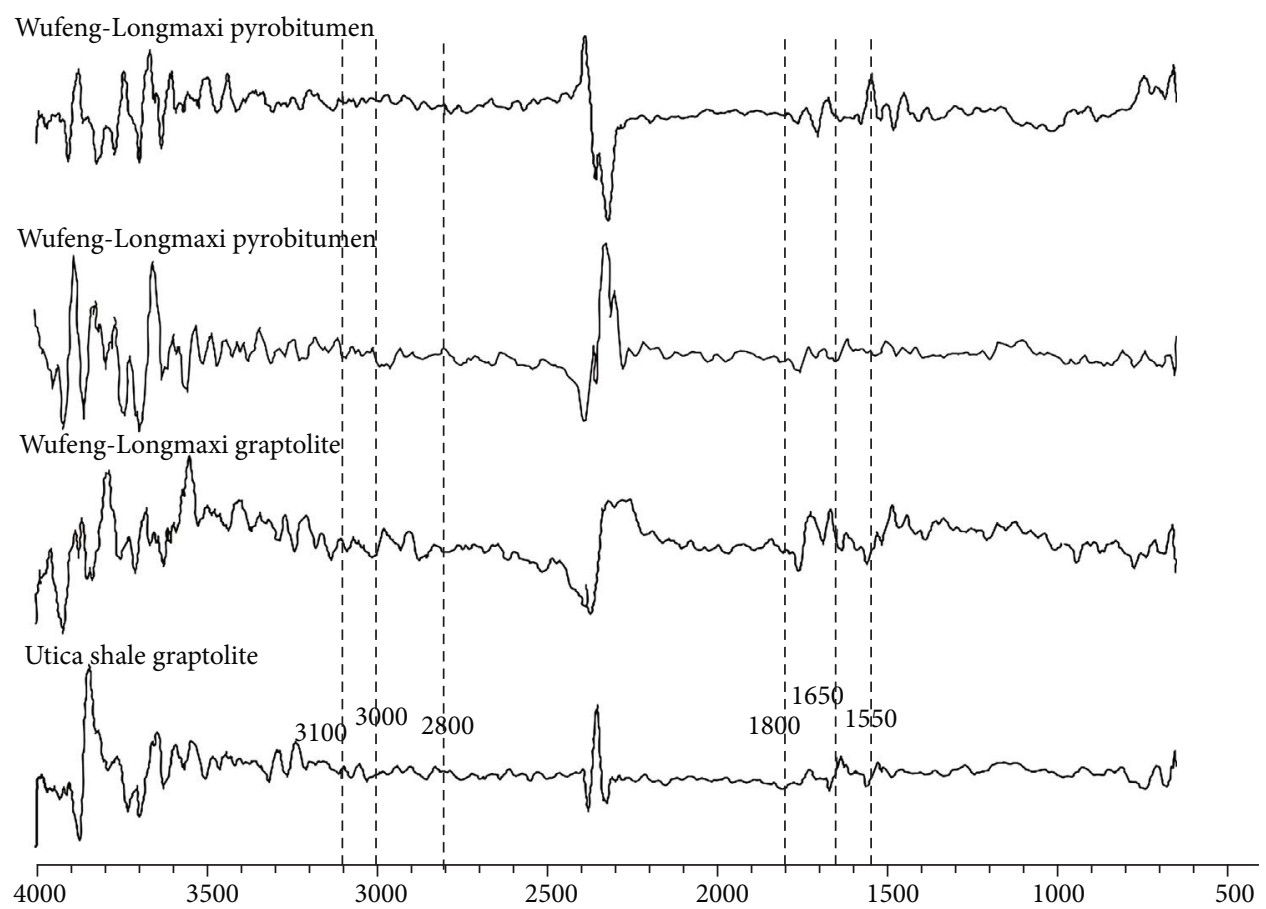

(a)

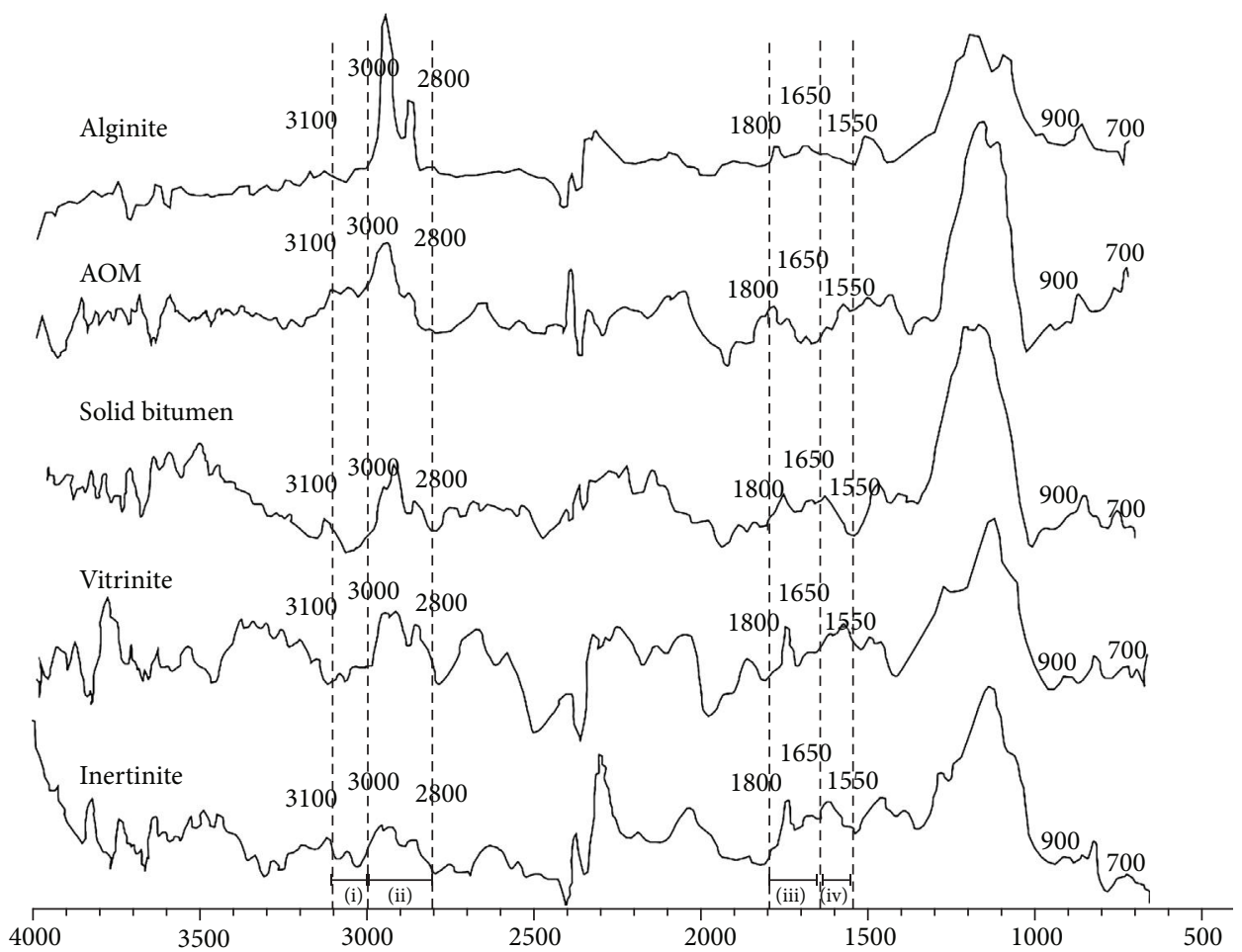

(b)

FIGURE 17: (a) Micro-FTIR spectra of pyrobitumen and graptolite in studied samples. The first two are of pyrobitumen, and the third and fourth show graptolite in Wufeng-Longmaxi shale and Utica shale, respectively. (b) Micro-FTIR spectra of alginite, AOM, solid bitumen, vitrinite, and inertinite from New Albany Shale samples $\left(\mathrm{VR}_{\mathrm{o}}=0.63 \%\right)$ (adapted from [89]).

kerogen type III) and gas-prone biomacromolecules [121, 122]. Dutta et al. [123], using SEM images, suggested that chitinozoans originally are devoid of any porosity in their structure, and based on their kerogen composition, pores are not expected to develop during thermal maturation. Our FTIR analysis further suggests that the chemical composition of graptolite periderm is indeed similar to vitrinite and inertinite, which are major components of type III kerogens; 
i.e., they contain a large amount of oxygen-containing functional groups and aromatic groups [121]. Reyes et al. [122] suggested that chitinozoans and graptolites had limited or no contribution to overall hydrocarbon generation because morphological evidence of the thermal decomposition in the immature to gas generation window under SEM is unavailable. Our FTIR data show that at the maturity corresponding to $\mathrm{VR}_{\mathrm{o}} \sim 2.45 \%$, pyrobitumen lost its hydrocarbon-generating potential and only some $\mathrm{C}=\mathrm{O}$ and $\mathrm{C}=\mathrm{C}$ groups are detected in the spectra.

\section{Conclusions}

In this study, postmature Ordovician to Early Silurian Wufeng-Longmaxi shale samples were collected from Sichuan Basin in South China to investigate OM types and their associated pore structures by correlative organic petrographic and SEM analyses and various porosimetry measurements. For comparison, organic petrographic and SEM analyses were performed on the age-equivalent Utica shale from the U.S., overmature marine shale from Xiuwu Basin, and marine-continental transitional shale from Ordos Basin in China.

Quartz content shows different relationships with TOC content in studied Wufeng-Longmaxi shales due to quartz origin difference. Quartz content is positively correlated with TOC content in clay-poor shales (clay mineral content $<\sim$ $35 \%$ ), indicating quartz mainly of biogenic origins, whereas it exhibits no correlation with TOC in clay-rich shales, indicating quartz mainly of detrital origins. OM is the predominant controlling factor on micropores and also controls macropore development when TOC content increased to a certain level. Clay mineral and quartz contents also make different contributions to pore development.

In both Wufeng-Longmaxi shale and Utica shale, pyrobitumen and zooclasts were the dominant $\mathrm{OM}$ components, but their relative proportions varied. Specifically, pyrobitumen was dominant in Wufeng-Longmaxi shale, whereas zooclasts (and graptolites, in particular) were dominant in Utica shale. Pyrobitumen in Wufeng-Longmaxi shale was classified into three types according to morphological and internal structure differences. Each type of pyrobitumen owns distinct forms, and pore development within is highly heterogeneous. Specifically, pores are universally and uniformly developed in pyrobitumen I and abundantly developed in pyrobitumen III as bacteria-like aggregates but not well developed in pyrobitumen II nor graptolites. Pores developed in pyrobitumen I were most strongly influenced by hydrocarbon generation. Pyrobitumen II is a highly condensed form resulting from high compaction and hightemperature evaporation.

At the overmature maturation level $\left(\mathrm{VR}_{\mathrm{o}} \sim 2.4 \%\right)$, neither graptolites nor pyrobitumens have hydrocarbon-generating potential, as indicated by their aromatic nature and almost total absence of aliphatic hydrogen functionalities.

At the scale detected by SEM, most pyrobitumens were very porous, providing space for gas storage. In contrast, zero to very limited pores were documented in zooclasts, suggesting that while they contribute to the total OM content, they do not contribute space for gas storage or migration in these rocks. The high abundance of pyrobitumen in organic matter is the main contribution to pore development. These observations suggest that the proportions of pyrobitumen to zooclasts in the total OM may play an important role in predicting organic porosity and, ultimately, storage capacity of Ordovician-Silurian shales.

The types and sources of some organic matter are indistinguishable due to overly high maturity and compaction deformation. Nevertheless, the identification of typical maceral and related pore distributions is meaningful for better understanding the generation and preservation of shale gas and pore development mechanisms.

\section{Data Availability}

The data used to support the findings of this study are available from the first author upon request.

\section{Conflicts of Interest}

We declare that we do not have any commercial or associative interest that represents a conflict of interest in connection with the work submitted.

\section{Acknowledgments}

This work was supported by the Fundamental Research Funds for China University of Geosciences (Beijing) under Award Numbers 35832019035 and 53200759769 . Financial support from the National Natural Science Foundation of China under Award Number 41702133 is also greatly appreciated.

\section{References}

[1] J. B. Curtis, "Fractured shale-gas systems," AAPG Bulletin, vol. 86, pp. 1921-1938, 2002.

[2] S. Bernard, B. Horsfield, H.-M. Schulz, R. Wirth, A. Schreiber, and N. Sherwood, "Geochemical evolution of organic-rich shales with increasing maturity: a STXM and TEM study of the Posidonia Shale (Lower Toarcian, northern Germany)," Marine and Petroleum Geology, vol. 31, no. 1, pp. 70-89, 2012.

[3] Y. Chen, L. Wei, M. Mastalerz, and A. Schimmelmann, "The effect of analytical particle size on gas adsorption porosimetry of shale," International Journal of Coal Geology, vol. 138, pp. 103-112, 2015.

[4] M. E. Curtis, B. J. Cardott, C. H. Sondergeld, and C. S. Rai, "Development of organic porosity in the Woodford Shale with increasing thermal maturity," International Journal of Coal Geology, vol. 103, pp. 26-31, 2012.

[5] R. G. Loucks and R. M. Reed, "Scanning-electron-microscope petrographic evidence for distinguishing organic-matter pores associated with depositional organic matter versus migrated organic matter in mudrocks," Gulf Coast Association of Geological Societies Transactions, vol. 64, p. 713, 2014.

[6] D. Misch, F. Mendez-Martin, G. Hawranek, P. Onuk, D. Gross, and R. F. Sachsenhofer, "SEM and FIB-SEM investigations on potential gas shales in the Dniepr-Donets Basin (Ukraine): pore space evolution in organic matter during 
thermal maturation," IOP Conference Series: Materials Science and Engineering, vol. 109, article 012010, 2016.

[7] M.-F. Romero-Sarmiento, M. Ducros, B. Carpentier et al., "Quantitative evaluation of TOC, organic porosity and gas retention distribution in a gas shale play using petroleum system modeling: application to the Mississippian Barnett Shale," Marine and Petroleum Geology, vol. 45, pp. 315-330, 2013.

[8] M. D. Sun, B. S. Yu, Q. H. Hu et al., "Pore characteristics of Longmaxi shale gas reservoir in the northwest of Guizhou, China: investigations using small-angle neutron scattering (SANS), helium pycnometry, and gas sorption isotherm," International Journal of Coal Geology, vol. 171, pp. 61-68, 2017.

[9] M. D. Sun, B. S. Yu, Q. H. Hu, R. Yang, Y. Zhang, and B. Li, "Pore connectivity and tracer migration of typical shales in South China," Fuel, vol. 203, pp. 32-46, 2017.

[10] F. Yang, Z. Ning, Q. Wang, R. Zhang, and B. M. Krooss, "Pore structure characteristics of Lower Silurian shales in the southern Sichuan Basin, China: insights to pore development and gas storage mechanism," International Journal of Coal Geology, vol. 156, pp. 12-24, 2016.

[11] K. Zhang, J. Peng, W. Liu et al., "The role of deep geofluids in the enrichment of sedimentary organic matter: a case study of the Late Ordovician-Early Silurian in the Upper Yangtze region and Early Cambrian in the Lower Yangtze region, South China," Geofluids, vol. 2020, Article ID 8868638, 12 pages, 2020.

[12] W. Zhao, J. Li, T. Yang, S. Wang, and J. Huang, "Geological difference and its significance of marine shale gases in South China," Petroleum Exploration and Development, vol. 43, no. 4, pp. 547-559, 2016.

[13] J. Zhao, Z. K. Jin, Z. J. Jin, X. Wen, and Y. Geng, "Origin of authigenic quartz in organic-rich shales of the Wufeng and Longmaxi Formations in the Sichuan Basin, South China: implications for pore evolution," Journal of Natural Gas Science and Engineering, vol. 38, pp. 21-38, 2017.

[14] K. S. W. Sing, "Reporting physisorption data for gas/solid systems with special reference to the determination of surface area and porosity (Recommendations 1984)," Pure Applied Chemistry, vol. 57, no. 4, pp. 603-619, 1985.

[15] R. G. Loucks, R. M. Reed, S. C. Ruppel, and U. Hammes, "Spectrum of pore types and networks in mudrocks and a descriptive classification for matrix-related mudrock pores," AAPG Bulletin, vol. 96, no. 6, pp. 1071-1098, 2012.

[16] M. Mastalerz, A. Schimmelmann, A. Drobniak, and Y. Chen, "Porosity of Devonian and Mississippian New Albany Shale across a maturation gradient: insights from organic petrology, gas adsorption, and mercury intrusion," AAPG Bulletin, vol. 97, no. 10, pp. 1621-1643, 2013.

[17] K. L. Milliken, M. Rudnicki, D. N. Awwiller, and T. Zhang, "Organic matter-hosted pore system, Marcellus Formation (Devonian), Pennsylvania,” AAPG Bulletin, vol. 97, no. 2, pp. 177-200, 2013.

[18] M. Pommer and K. Milliken, "Pore types and pore-size distributions across thermal maturity, Eagle Ford Formation, southern Texas," AAPG Bulletin, vol. 99, no. 9, pp. 17131744, 2015.

[19] M. D. Sun, J. L. Zhao, Z. J. Pan et al., "Pore characterization of shales: a review of small angle scattering technique," Journal of Natural Gas Science and Engineering, vol. 78, article 103294, 2020.
[20] M. D. Sun, L. H. Zhang, Q. H. Hu et al., "Multiscale connectivity characterization of marine shales in southern China by fluid intrusion, small-angle neutron scattering (SANS), and FIB-SEM," Marine and Petroleum Geology, vol. 112, article 104101, 2020.

[21] L. T. Ko, G. L. Loucks, T. Zhang, S. C. Ruppel, and D. Shao, "Pore and pore network evolution of Upper Cretaceous Boquillas (Eagle Ford-equivalent) mudrocks: results from gold tube pyrolysis experiments," AAPG Bulletin, vol. 100, no. 11, pp. 1693-1722, 2016.

[22] Q. R. Passey, K. M. Bohacs, W. L. Esch, R. Klimentidis, and S. Sinha, "From oil-prone source rock to gas-producing shale reservoir - geologic and petrophysical characterization of unconventional shale-gas reservoirs," in CPS/SPE International Oil Gas Conference and Exhibition, Beijing, China, 2010.

[23] R. M. Slatt and N. R. O'Brien, "Pore types in the Barnett and Woodford gas shales: contribution to understanding gas storage and migration pathways in fine-grained rocks," $A A P G$ Bulletin, vol. 95, no. 12, pp. 2017-2030, 2011.

[24] F. Javadpour, D. Fisher, and M. Unsworth, "Nanoscale gas flow in shale gas sediments," Journal of Canadian Petroleum Technology, vol. 46, no. 10, pp. 55-61, 2007.

[25] Y. Li, Y. Wang, J. Wang, and Z. Pan, "Variation in permeability during $\mathrm{CO}_{2}-\mathrm{CH}_{4}$ displacement in coal seams: part 1 - experimental insights," Fuel, vol. 263, article 116666, 2020.

[26] L. Wei, M. Mastalerz, A. Schimmelmann, and Y. Chen, "Influence of Soxhlet-extractable bitumen and oil on porosity in thermally maturing organic-rich shales," International Journal of Coal Geology, vol. 132, pp. 38-50, 2014.

[27] B. J. Cardott, C. R. Landis, and M. E. Curtis, "Post-oil solid bitumen network in the Woodford Shale, USA - a potential primary migration pathway," International Journal of Coal Geology, vol. 139, pp. 106-113, 2015.

[28] T. Dong, S. He, M. Chen et al., "Quartz types and origins in the Paleozoic Wufeng-Longmaxi Formations, eastern Sichuan Basin, China: implications for porosity preservation in shale reservoirs," Marine and Petroleum Geology, vol. 106, pp. 62-73, 2019.

[29] R. G. Loucks, R. M. Reed, S. C. Ruppel, and D. M. Jarvie, "Morphology, genesis, and distribution of nanometer-scale pores in siliceous mudstones of the Mississippian Barnett Shale," Journal of Sedimentary Research, vol. 79, no. 12, pp. 848-861, 2009.

[30] O. H. Ardakani, H. Sanei, A. Ghanizadeh, M. McMechan, F. Ferri, and C. R. Clarkson, "Hydrocarbon potential and reservoir characteristics of Lower Cretaceous Garbutt Formation, Liard Basin Canada," Fuel, vol. 209, pp. 274-289, 2017.

[31] N. S. Fishman, P. C. Hackley, H. A. Lowers et al., "The nature of porosity in organic-rich mudstones of the Upper Jurassic Kimmeridge Clay Formation, North Sea, offshore United Kingdom," International Journal of Coal Geology, vol. 103, pp. 32-50, 2012.

[32] W. Ji, F. Hao, H. Schulz, Y. Song, and J. Tian, "The architecture of organic matter and its pores in highly mature gas shales of the Lower Silurian Longmaxi Formation in the Upper Yangtze Platform, South China," AAPG Bulletin, vol. 103, no. 12, pp. 2909-2942, 2019.

[33] R. G. Loucks, R. M. Reed, S. C. Ruppel, and U. Hammes, "Preliminary classification of matrix pores in mudrocks," 
Gulf Coast Association of Geological Societies Transactions, vol. 60, pp. 435-441, 2010.

[34] H. Nie, Z. Jin, and J. Zhang, "Characteristics of three organic matter pore types in the Wufeng-Longmaxi shale of the Sichuan Basin, Southwest China," Scientific reports, vol. 8, no. 1, p. 7014, 2018.

[35] J. Schieber, "Common themes in the formation and preservation of intrinsic porosity in shales and mudstones - illustrated with examples across the Phanerozoic," in Society of Petroleum Engineers Unconventional Gas Conference, Pittsburgh, Pennsylvania, U.S, 2010.

[36] K. Zhang, Y. Song, S. Jiang et al., "Shale gas accumulation mechanism in a syncline setting based on multiple geological factors: an example of southern Sichuan and the Xiuwu Basin in the Yangtze region," Fuel, vol. 241, pp. 468-476, 2019.

[37] X. Guo, Z. Qin, R. Yang et al., "Comparison of pore systems of clay-rich and silica-rich gas shales in the Lower Silurian Longmaxi Formation from the Jiaoshiba area in the eastern Sichuan Basin, China," Marine and Petroleum Geology, vol. 101, pp. 265-280, 2019.

[38] W. Ji, Y. Song, Z. Jiang et al., "Fractal characteristics of nanopores in the Lower Silurian Longmaxi shales from the Upper Yangtze Platform, South China," Marine and Petroleum Geology, vol. 78, pp. 88-98, 2016.

[39] J. Chen and X. Xiao, "Evolution of nanoporosity in organicrich shales during thermal maturation," Fuel, vol. 129, pp. 173-181, 2014.

[40] J. Chen, F. Jiang, T. Hu et al., "Experimental investigation of the characteristics of organic matter pores in Chang $7 \mathrm{mem}$ ber lacustrine shale from the Ordos Basin due to organic matter evolution induced by hydrous pyrolysis," Journal of Natural Gas Science and Engineering, vol. 35, pp. 412-424, 2016.

[41] W. Yang, R. S. Zuo, Z. X. Jiang et al., "Effect of lithofacies on pore structure and new insights into pore-preserving mechanisms of the over-mature Qiongzhusi marine shales in Lower Cambrian of the southern Sichuan Basin, China," Marine and Petroleum Geology, vol. 98, pp. 746-762, 2018.

[42] K. Zhang, J. Peng, X. Wang et al., "Effect of organic maturity on shale gas genesis and pores development: a case study on marine shale in the Upper Yangtze region, South China," Open Geosciences, vol. 12, no. 1, pp. 1617-1629, 2020.

[43] O. H. Ardakani, H. Sanei, A. Ghanizadeh, D. Lavoie, Z. Chen, and C. R. Clarkson, "Do all fractions of organic matter contribute equally in shale porosity? A case study from Upper Ordovician Utica shale, southern Quebec, Canada," Marine and Petroleum Geology, vol. 92, pp. 794-808, 2018.

[44] G. R. L. Chalmers and R. M. Bustin, "A multidisciplinary approach in determining the maceral (kerogen type) and mineralogical composition of Upper Cretaceous Eagle Ford Formation: impact on pore development and pore size distribution," International Journal of Coal Geology, vol. 171, pp. 93-110, 2017.

[45] B. Liu, J. Schieber, and M. Mastalerz, "Combined SEM and reflected light petrography of organic matter in the New Albany Shale (Devonian-Mississippian) in the Illinois Basin: a perspective on organic pore development with thermal maturation," International Journal of Coal Geology, vol. 184, pp. 57-72, 2017.

[46] S. C. Löhr, E. T. Baruch, P. A. Hall, and M. J. Kennedy, "Is organic pore development in gas shales influenced by the primary porosity and structure of thermally immature organic matter?," Organic Geochemistry, vol. 87, pp. 119132, 2015.

[47] J. Teng, M. Mastalerz, and L. Hampton, "Maceral controls on porosity characteristics of lithotypes of Pennsylvanian high volatile bituminous coal: example from the Illinois Basin," International Journal of Coal Geology, vol. 172, pp. 80-94, 2017.

[48] P. C. Hackley and B. J. Cardott, "Application of organic petrography in North American shale petroleum systems: a review," International Journal of Coal Geology, vol. 163, pp. 8-51, 2016.

[49] B. P. Tissot and D. H. Welte, Petroleum Formation and Occurrence, Springer Berlin Heidelberg, Berlin, 2nd Edition edition, 1984.

[50] ICCP (International Commission for Coal Petrology), International Handbook of Coal Petrography, 2nd Supplement to, Centre National de la Recherche Scientifique, Paris, 2nd Edition edition, 1975.

[51] Y. Li, J. Yang, Z. Pan, and W. Tong, "Nanoscale pore structure and mechanical property analysis of coal: an insight combining AFM and SEM images," Fuel, vol. 260, article 116352, 2020.

[52] R. W. T. Wilkins, J. R. Wilmshurst, N. J. Russell, G. Hladky, M. V. Ellacott, and C. Buckingham, "Fluorescence alteration and the suppression of vitrinite reflectance," Organic Geochemistry, vol. 18, no. 5, pp. 629-640, 1992.

[53] O. Haeri-Ardakani, H. Sanei, D. Lavoie, Z. Chen, and C. Jiang, "Geochemical and petrographic characterization of the Upper Ordovician Utica shale, southern Quebec, Canada," International Journal of Coal Geology, vol. 138, pp. 83-94, 2015.

[54] G. Hu, Q. Pang, K. Jiao, C. Hu, and Z. Liao, "Development of organic pores in the Longmaxi Formation overmature shales: combined effects of thermal maturity and organic matter composition," Marine and Petroleum Geology, vol. 116, article 104314, 2020.

[55] Q. Luo, N. Zhong, N. Dai, and W. Zhang, "Graptolite-derived organic matter in the Wufeng-Longmaxi Formations (Upper Ordovician-Lower Silurian) of southeastern Chongqing, China: implications for gas shale evaluation," International Journal of Coal Geology, vol. 153, pp. 87-98, 2016.

[56] Y. Ma, N. Zhong, L. Cheng et al., "Pore structure of the graptolite-derived $\mathrm{OM}$ in the Longmaxi shale, southeastern Upper Yangtze region, China," Marine and Petroleum Geology, vol. 72, pp. 1-11, 2016.

[57] T. Guo, "The Fuling shale gas field-a highly productive Silurian gas shale with high thermal maturity and complex evolution history, southeastern Sichuan Basin, China," Interpretation, vol. 3, no. 2, pp. SJ25-SJ34, 2015.

[58] X. Guo, Y. Li, R. Liu, and Q. Wang, "Characteristics and controlling factors of micropore structures of the Longmaxi shale in the Jiaoshiba area, Sichuan Basin," Natural Gas Industry B, vol. 1, no. 2, pp. 165-171, 2014.

[59] J. Tan, B. Horsfield, N. Mahlstedt et al., "Natural gas potential of Neoproterozoic and Lower Palaeozoic marine shales in the Upper Yangtze Platform, South China: geological and organic geochemical characterization," International Geology Review, vol. 57, no. 3, pp. 305-326, 2015.

[60] K. Zhang, C. Z. Jia, Y. Song et al., "Analysis of Lower Cambrian shale gas composition, source and accumulation pattern in different tectonic backgrounds: a case study of 
Weiyuan block in the Upper Yangtze region and Xiuwu Basin in the Lower Yangtze region," Fuel, vol. 263, article 115978, 2020.

[61] C. Zou, D. Dong, Y. Wang et al., "Shale gas in China: characteristics, challenges and prospects (II)," Petroleum Exploration and Development, vol. 43, no. 2, pp. 182-196, 2016.

[62] F. Goodarzi, "Organic petrography of graptolite fragments from Turkey," Marine and Petroleum Geology, vol. 1, no. 3, pp. 202-210, 1984.

[63] I. Suárez-Ruiz, D. Flores, J. G. Mendonça Filho, and P. C. Hackley, "Review and update of the applications of organic petrology: part 1, geological applications," International Journal of Coal Geology, vol. 99, pp. 54-112, 2012.

[64] V. Suchý, I. Sýkorová, M. Stejskal, J. Šafanda, Vladimír Machovič, and M. Novotná, "Dispersed organic matter from Silurian shales of the Barrandian Basin, Czech Republic: optical properties, chemical composition and thermal maturity," International Journal of Coal Geology, vol. 53, no. 1 , pp. 1-25, 2002.

[65] H. Tian, L. Pan, X. Xiao, R. W. Wilkins, Z. Meng, and B. Huang, "A preliminary study on the pore characterization of Lower Silurian black shales in the Chuandong Thrust Fold Belt, southwestern China using low pressure $\mathrm{N}_{2}$ adsorption and FE-SEM methods," Marine and Petroleum Geology, vol. 48, pp. 8-19, 2013.

[66] S. İnan, H. Al Badairy, T. İnan, and A. Al Zahrani, "Formation and occurrence of organic matter-hosted porosity in shales," International Journal of Coal Geology, vol. 199, pp. 39-51, 2018.

[67] J. Klaver, G. Desbois, R. Littke, and J. L. Urai, "BIB-SEM characterization of pore space morphology and distribution in postmature to overmature samples from the Haynesville and Bossier Shales," Marine and Petroleum Geology, vol. 59, pp. 451-466, 2015.

[68] W. Ji, Y. Song, Z. Rui, M. Meng, and H. Huang, "Pore characterization of isolated organic matter from high matured gas shale reservoir," International Journal of Coal Geology, vol. 174, pp. 31-40, 2017.

[69] W. Yang, S. He, S. Iglauer et al., "Porosity characteristics of different lithofacies in marine shale: a case study of Neoproterozoic Sinian Doushantuo Formation in Yichang area, China," Journal of Petroleum Science and Engineering, vol. 187, article 106856, 2020.

[70] W. Yang, R. S. Zuo, D. X. Chen et al., "Climate and tectonicdriven deposition of sandwiched continental shale units: new insights from petrology, geochemistry, and integrated provenance analyses (the western Sichuan subsiding basin, Southwest China)," International Journal of Coal Geology, vol. 211, article 103227, 2019.

[71] Z. Chen, D. Lavoie, M. Malo, C. Jiang, H. Sanei, and O. Ardakani, "A dual-porosity model for evaluating petroleum resource potential in unconventional tight-shale plays with application to Utica shale, Quebec (Canada)," Marine and Petroleum Geology, vol. 80, pp. 333-348, 2017.

[72] D. Lavoie, C. Rivard, R. Lefebvre et al., "The Utica shale and gas play in southern Quebec: geological and hydrogeological syntheses and methodological approaches to groundwater risk evaluation," International Journal of Coal Geology, vol. 126, pp. 77-91, 2014.

[73] C. Rivard, D. Lavoie, R. Lefebvre, S. Séjourné, C. Lamontagne, and M. J. Duchesne, "An overview of Canadian shale gas pro- duction and environmental concerns," International Journal of Coal Geology, vol. 126, pp. 64-76, 2014.

[74] F. Gao, Y. Song, Z. Li et al., "Pore characteristics and dominant controlling factors of overmature shales: a case study of the Wangyinpu and Guanyintang Formations in the Jiangxi Xiuwu Basin," Interpretation, vol. 6, no. 2, pp. T393-T412, 2018.

[75] Y. Li, J. Yang, Z. Pan, S. Meng, K. Wang, and $X$. NiuUnconventional natural gas accumulations in stacked deposits: a discussion of Upper Paleozoic coal-bearing strata in the east margin of the Ordos Basin, China," Acta Geologica Sinica (English Edition), vol. 93, no. 1, pp. 111-129, 2019.

[76] Y. Wang, L. Wang, J. Wang, Z. Jiang, C. Jin, and Y. Wang, "Characterization of organic matter pores in typical marine and terrestrial shales, China," Journal of Natural Gas Science and Engineering, vol. 49, pp. 56-65, 2018.

[77] W. Yang, Q. Y. Wang, Y. H. Wang et al., "Pore characteristic responses to categories of depositional microfacies of deltalacustrine tight reservoirs in the Upper Triassic Yanchang Formation, Ordos Basin, NW China," Marine and Petroleum Geology, vol. 118, article 104423, 2020.

[78] C. Orr, "Surface area measurement," in Treatise on Analytical Chemistry: Part III. Analytical Chemistry in Industry, I. M. Kolthoff, P. J. Elving, and F. H. Stross, Eds., vol. 4, pp. 321358, John Wiley and Sons, New York, 1977.

[79] C. R. Clarkson and R. Marc Bustin, "Variation in micropore capacity and size distribution with composition in bituminous coal of the Western Canadian Sedimentary Basin: implications for coalbed methane potential," Fuel, vol. 75, no. 13, pp. 1483-1498, 1996.

[80] C. R. Clarkson, M. Freeman, L. He et al., "Characterization of tight gas reservoir pore structure using USANS/SANS and gas adsorption analysis," Fuel, vol. 95, pp. 371-385, 2012.

[81] M. Mastalerz, A. Drobniak, D. Strąpoć, W. Solano Acosta, and J. Rupp, "Variations in pore characteristics in high volatile bituminous coals: implications for coal bed gas content," International Journal of Coal Geology, vol. 76, no. 3, pp. 205216, 2008.

[82] S. J. Gregg and K. S. W. Sing, Adsorption, Surface Area, and Porosity, Academic Press, New York, 1982.

[83] P. A. Webb and C. Orr, Analytical Methods in Fine Particle Technology, Micromeritics Instrument, Norcross, 1997.

[84] E. W. Washburn, "Note on a method of determining the distribution of pore sizes in a porous material," Proceedings of the National Academy of Science, vol. 7, no. 4, pp. 115-116, 1921.

[85] Y. Wang, L. Liu, S. Zheng, Z. Luo, Y. Sheng, and X. Wang, "Full-scale pore structure and its controlling factors of the Wufeng-Longmaxi shale, southern Sichuan Basin, China: implications for pore evolution of highly overmature marine shale," Journal of Natural Gas Science and Engineering, vol. 67, pp. 134-146, 2019.

[86] W. P. Diamond and S. J. Schatzel, "Measuring the gas content of coal: a review," International Journal of Coal Geology, vol. 35 , no. 1-4, pp. 311-331, 1998.

[87] M. Gasparik, A. Ghanizadeh, P. Bertier, Y. Gensterblum, S. Bouw, and B. M. Krooss, "High-pressure methane sorption isotherms of black shales from the Netherlands," Energy of Fuels, vol. 26, no. 8, pp. 4995-5004, 2012. 
[88] B. M. Krooss, F. van Bergen, Y. Gensterblum, N. Siemons, H. J. M. Pagnier, and P. David, "High-pressure methane and carbon dioxide adsorption on dry and moisture- equilibrated Pennsylvanian coals," International Journal of Coal Geology, vol. 51, no. 2, pp. 69-92, 2002.

[89] L. Wei, Y. Wang, and M. Mastalerz, "Comparative optical properties of macerals and statistical evaluation of mis- identification of vitrinite and solid bitumen from early mature Middle Devonian - Lower Mississippian New Albany Shale: implications for thermal maturity assessment," International Journal of Coal Geology, vol. 168, pp. 222-236, 2016.

[90] P. C. Painter, R. W. Snyder, M. Starsinic, M. M. Coleman, D. W. Kuehn, and A. Davis, "Concerning the application of FTIR to the study of coal: a critical assessment of band assignments and the application of spectral analysis programs," Applied Spectroscopy, vol. 35, no. 5, pp. 475-485, 1981.

[91] P. Painter, M. Starsinic, and M. Coleman, "Determination of functional groups in coal by Fourier transform interferometry," in Fourier Transform Infrared Spectra: Applications to Chemical Systems, pp. 169-240, Academic press, 1985.

[92] S. H. Wang and P. R. Griffiths, "Resolution enhancement of diffuse reflectance i.r. spectra of coals by Fourier self-deconvolution: 1. C-H stretching and bending modes," Fuel, vol. 64, no. 2, pp. 229-236, 1985.

[93] H. Jacob, "Classification, structure, genesis and practical importance of natural solid oil bitumen ("migrabitumen")," International Journal of Coal Geology, vol. 11, no. 1, pp. 6579, 1989.

[94] C. R. Landis and J. R. Castaño, "Maturation and bulk chemical properties of a suite of solid hydrocarbons," Organic Geochemistry, vol. 22, no. 1, pp. 137-149, 1995.

[95] R. Bertrand and M. Malo, "Source rock analysis, thermal maturation and hydrocarbon generation in Siluro-Devonian rocks of the Gaspe Belt basin, Canada," Bulletin of Canadian Petroleum Geology, vol. 49, no. 2, pp. 238-261, 2001.

[96] W. R. Evitt, “A discussion and proposals concerning fossil dinoflagellates, hystrichospheres, and acritarchs, I," Proceedings of the National Academy of Sciences of the United States of America, vol. 49, no. 2, pp. 158-164, 1963.

[97] Y. Ma, N. Zhong, D. Li, Z. Pan, L. Cheng, and K. Liu, "Organic matter/clay mineral intergranular pores in the Lower Cambrian Lujiaping Shale in the north-eastern part of the Upper Yangtze area, China: a possible microscopic mechanism for gas preservation," International Journal of Coal Geology, vol. 137, pp. 38-54, 2015.

[98] D. Misch, D. Gross, G. Hawranek et al., "Solid bitumen in shales: petrographic characteristics and implications for reservoir characterization," International Journal of Coal Geology, vol. 205, pp. 14-31, 2019.

[99] Y. Chen, M. Mastalerz, and A. Schimmelmann, "Characterization of chemical functional groups in macerals across different coal ranks via micro-FTIR spectroscopy," International Journal of Coal Geology, vol. 104, pp. 22-33, 2012.

[100] Y. Wang, L. Liu, S. Li et al., "The forming mechanism and process of tight oil sand reservoirs: a case study of Chang 8 oil layers of the Upper Triassic Yanchang Formation in the western Jiyuan area of the Ordos Basin, China," Journal of Petroleum Science and Engineering, vol. 158, pp. 29-46, 2017.

[101] C. Wu, J. Tuo, L. Zhang et al., "Pore characteristics differences between clay-rich and clay-poor shales of the Lower Cambrian Niutitang Formation in the northern Guizhou area, and insights into shale gas storage mechanisms," International Journal of Coal Geology, vol. 178, pp. 13-25, 2017.

[102] R. Yang, S. He, D. F. Hu, D. Hu, S. Zhang, and J. Yi, "Pore characterization and methane sorption capacity of overmature organic- rich Wufeng and Longmaxi shales in the southeast Sichuan Basin, China," Marine and Petroleum Geology, vol. 77, pp. 247-261, 2016.

[103] D. J. K. Ross and R. Marc Bustin, "The importance of shale composition and pore structure upon gas storage potential of shale gas reservoirs," Marine and Petroleum Geology, vol. 26, no. 6, pp. 916-927, 2009.

[104] G. R. L. Chalmers, D. J. K. Ross, and R. M. Bustin, “Geological controls on matrix permeability of Devonian gas shales in the Horn River and Liard Basins, northeastern British Columbia, Canada," International Journal of Coal Geology, vol. 103, pp. 120-131, 2012.

[105] C. Yang, J. Zhang, X. Wang et al., "Nanoscale pore structure and fractal characteristics of a marine-continental transitional shale: a case study from the Lower Permian Shanxi Shale in the southeastern Ordos Basin, China," Marine and Petroleum Geology, vol. 88, pp. 54-68, 2017.

[106] D. P. Le Heron, Y. Khoukhi, F. Paris, J.-F. Ghienne, and A. Le Herissé, "Black shale, grey shale, fossils and glaciers: anatomy of the Upper Ordovician-Silurian succession in the Tazzeka Massif of eastern Morocco," Gondwana Research, vol. 14, no. 3, pp. 483-496, 2008.

[107] S. Lüning, Y. M. Shahin, D. Loydell et al., "Anatomy of a world-class source rock: distribution and depositional model of Silurian organic-rich shales in Jordan and implications for hydrocarbon potential," AAPG Bulletin, vol. 89, no. 10, pp. 1397-1427, 2005.

[108] H. Hu, F. Hao, J. Lin, Y. Lu, Y. Ma, and Q. Li, “Organic matter-hosted pore system in the Wufeng-Longmaxi $\left(\mathrm{O}_{3} \mathrm{w}\right.$ $\left.\mathrm{S}_{1} 1\right)$ shale, Jiaoshiba area, eastern Sichuan Basin, China," International Journal of Coal Geology, vol. 173, pp. 40-50, 2017.

[109] N. D. Rodriguez and R. P. Philp, "Geochemical characterization of gases from the Mississippian Barnett Shale, Fort Worth Basin, Texas," AAPG Bulletin, vol. 94, no. 11, pp. 1641-1656, 2010.

[110] R. M. Slatt and N. D. Rodriguez, "Comparative sequence stratigraphy and organic geochemistry of gas shales: commonality or coincidence?," Journal of Natural Gas Science and Engineering, vol. 8, pp. 68-84, 2012.

[111] M. Mastalerz, A. Drobniak, and A. B. Stankiewicz, "Origin, properties, and implications of solid bitumen in source-rock reservoirs: a review," International Journal of Coal Geology, vol. 195, pp. 14-36, 2018.

[112] P. C. Hackley, B. J. Valentine, and J. J. Hatcherian, “On the petrographic distinction of bituminite from solid bitumen in immature to early mature source rocks," International Journal of Coal Geology, vol. 196, pp. 232-245, 2018.

[113] Y. Hou, K. Zhang, F. Wang et al., "Structural evolution of organic matter and implications for graphitization in overmature marine shales, South China," Marine and Petroleum Geology, vol. 109, pp. 304-316, 2019.

[114] R. Wang, Y. Gu, W. Ding et al., "Characteristics and dominant controlling factors of organic-rich marine shales with high thermal maturity: a case study of the Lower Cambrian Niutitang Formation in the Cen'gong block, southern China," Journal of Natural Gas Science and Engineering, vol. 33, pp. 81-96, 2016. 
[115] J. M. Wood, H. Sanei, O. Haeri-Ardakani, M. E. Curtis, T. Akai, and C. Currie, "Solid bitumen in the Montney Formation: diagnostic petrographic characteristics and significance for hydrocarbon migration," International Journal of Coal Geology, vol. 198, pp. 48-62, 2018.

[116] J. Dai, C. Zou, S. Liao et al., "Geochemistry of the extremely high thermal maturity Longmaxi shale gas, southern Sichuan Basin," Organic Geochemistry, vol. 74, pp. 3-12, 2014.

[117] S. Zhou, G. Yan, H. Xue, W. Guo, and X. Li, "2D and 3D nanopore characterization of gas shale in Longmaxi Formation based on FIB-SEM," Marine and Petroleum Geology, vol. 73, pp. 174-180, 2016.

[118] K. L. Milliken and M. E. Curtis, "Imaging pores in sedimentary rocks: foundation of porosity prediction," Marine and Petroleum Geology, vol. 73, pp. 590-608, 2016.

[119] F. Goodarzi, "Reflected light microscopy of chitinozoan fragments," Marine and Petroleum Geology, vol. 2, no. 1, pp. 7278, 1985.

[120] Y. Grahn and F. Paris, "Emergence, biodiversification and extinction of the chitinozoan group," Geological Magazine, vol. 148, no. 2, pp. 226-236, 2011.

[121] J. Jacob, F. Paris, O. Monod et al., "New insights into the chemical composition of chitinozoans," Organic Geochemistry, vol. 38, no. 10, pp. 1782-1788, 2007.

[122] J. Reyes, C. Jiang, D. Lavoie, D. K. Armstrong, M. Milovic, and R. Robinson, "Organic petrographic analysis of artificially matured chitinozoan- and graptolite-rich Upper Ordovician shale from Hudson Bay Basin, Canada," International Journal of Coal Geology, vol. 199, pp. 138-151, 2018.

[123] S. Dutta, C. Hartkopf-Fröder, K. Witte, R. Brocke, and U. Mann, "Molecular characterization of fossil palynomorphs by transmission micro-FTIR spectroscopy: implications for hydrocarbon source evaluation," International Journal of Coal Geology, vol. 115, pp. 13-23, 2013. 